\title{
Distribution and diversity of the Opheliidae (Annelida, Polychaeta) on the continental shelf and slope of Iceland, with a review of the genus Ophelina in northeast Atlantic waters and description of two new species
}

\author{
Julio Parapar ${ }^{\text {*, }}$, Juan Moreira ${ }^{2,3}$, Gudmundur V. Helgason ${ }^{4}$ \\ 1 Departamento de Bioloxía Animal, Bioloxía Vexetal e Ecoloxía, Facultade de Ciencias, \\ Universidade da Coruña, 15008 A Coruña, Spain e-mail: jparapar@udc.es \\ 2 Estación de Bioloxía Mariña da Graña, Universidade de Santiago de Compostela, Rúa da Ribeira \\ 1, A Graña, 15590 Ferrol, Spain \\ 3 Departamento de Biología (Zoología), Universidad Autónoma de Madrid, Cantoblanco, 28049 \\ Madrid, Spain \\ 4 Institute of Biology, University of Iceland, Sturlugata 7, 101 Reykjavik, Iceland
}

Organisms Diversity \& Evolution, June 2011, 11:83

Received: 1 November 2010 / Accepted: 28 April 2011 / Published online: 19 May 2011

(C) Gesellschaft für Biologische Systematik 2011

\section{Cite this article as:}

Parapar, J., Moreira, J. \& Helgason, G.V. Org Divers Evol (2011) 11: 83. doi:10.1007/s13127011-0046-2

The final publication is available at Springer via http://dx.doi.org/10.1007/s13127-011-0046-2

\begin{abstract}
The diversity, taxonomy and distribution of the Opheliidae (Annelida: Polychaeta) in Icelandic waters is reviewed based on material collected during the BIOICE project. Nine opheliid species are recorded from Iceland; of these, three were previously reported in the area (Ophelia limacina, Ophelina cylindricaudata and $O$. acuminata), four are new for Icelandic waters (Ammotrypanella cf. arctica, Ophelina abranchiata, O. helgolandica and Tachytrypane jeffreisii), and two are new to science. Ophelina basicirra sp. nov. is distinguished by having a narrow anal tube with one short proximal anal cirrus in ventral position. Ophelina bowitzi sp. nov. is characterized by the small size of its anterior branchiae, which become larger in the middle and posterior body regions, and by an upwardly bent anal tube that is wide at the base and narrowing distally. The genera Euzonus, Armandia and Polyophthalmus are not represented in the BIOICE samples. The distribution of each species off Iceland is presented; one species is restricted to shallow waters of northwestern fjords, three species are found south of the GIF Ridge, and five species are circumicelandic. Several body characters with taxonomic relevance in some species are reviewed based on SEM images. Furthermore, as a first step towards a future revision of the genus Ophelina Örsted 1843 in North Atlantic waters, the status of each species originally described or subsequently reported from the area is commented on, and a key to the currently valid species is presented. Ophelina longicephala Hartmann-Schröder, 1977, formerly a subspecies of $O$. delapidans (Kinberg, 1866), is raised to species status.
\end{abstract}




\section{Keywords}

Annelida; Ophelina; GIF Ridge; Deep sea; BIOICE project; SEM; Taxonomy; New species

\section{Introduction}

The Opheliidae (Annelida: Polychaeta) are marine subsurface dwellers with occurrences ranging from the intertidal zone to the deep sea; they are relevant components of the benthic infauna both in number of species and abundance (Hutchings 2000; Rouse 2001). Many opheliids are well characterized taxonomically, and their ecology and distribution are well documented, mostly in European waters (e.g. Bellan 1961, 1964, 1975, 2001; Bellan et al. 1990; Bellan and Costa 1987; Bellan and Picard 1965; Bellan-Santini et al. 1992; Dauvin and Bellan1994; Fauvel 1925, 1927; Hartmann-Schröder 1996; Hartmann-Schröder and Parker 1995; Riser 1987; StøpBowitz 1945, 1948, 1958; Tebble 1952). In recent years, significant efforts are being undertaken in non-European waters to determine the actual diversity of the family. Thus, new taxa have been described from the Pacific coast of North America (Blake 2000), the southwest Atlantic (Elías et al. 2003) and Antarctica (Maciolek and Blake 2006; Schüller 2008). Furthermore, some genera are now well established; for instance, Støp-Bowitz (1945) has synonymised Ammotrypane Rathke, 1843 with Ophelina Örsted 1843, and Tebble (1953) has reassessed the main diagnostic characters in Ophelia Savigny, 1822. Nevertheless, some confusion still exists in the delineation of many species. For example, in Nordic Seas (around Greenland, Iceland and Norway), some species have had their names synonymised without having been studied in depth, others have not been reported since their original description, and still others have remained known but undescribed (Hartmann-Schröder 1974). To date, seven genera of Opheliidae are reported in northeast Atlantic waters (NEAW) (Bellan 2001; Hansson 1998; Rowe 2010); a revision of the family in European waters is, therefore, highly desirable.

Because of its size and geographic location, Iceland is of great relevance for the study of marine biodiversity in North Atlantic waters, from the standpoint of taxonomy as well as those of ecology and biogeography. Indeed, Iceland covers a wide latitudinal range and is located in the centre of the Greenland-Iceland-Faeroe (GIF) Ridge, where water masses from Arctic and Nordic Seas converge with waters from the North Atlantic. Previous work has pointed out differences in faunal composition between the colder areas to the north of the GIF Ridge and the warmer areas to the south (Brix and Svavarsson 2010), but the factors which determine these patterns are still unclear.

Wesenberg-Lund (1951) compiled the information on Icelandic polychaetes from the first half of the 20th century. She mentioned the presence of the opheliids Ophelia limacina (Rathke,1843), Ophelina cylindricaudata (Hansen, 1878), O. acuminata Örsted 1843, and Travisia forbesii Johnston, 1840; the genus Travisia was recently placed in the family Scalibregmatidae Malmgren, 1867 by Bleidorn et al. (2003). Gardarsson (1973) and Helgason et al. (1990) also worked on Icelandic polychaetes but did not report any opheliids. There were, however, references to opheliids from nearby geographic areas, such as the Faeroe Islands (Ditlevsen1929), the North Sea and the Skagerrak (Eliason 1951, 1962) and Greenland (Wesenberg-Lund1950, 1953).

The BIOICE project began in 1992 with the aim of improving the knowledge on benthic biodiversity in the waters around Iceland, by means of a number of oceanographic expeditions. The sampling area covered a depth range from 20 to 3,500 m on both sides of the GIF Ridge, above which the waters are generally less than $500 \mathrm{~m}$ deep, and which constitutes the boundary between the relatively warm North Atlantic Ocean and the much colder Nordic seas of the Arctic Ocean (Brix and 
Svavarsson 2010; Sigvaldadóttir 2002; Weisshappel 2000). Examination of polychaete material collected during the BIOICE expeditions has led to several papers on taxonomy and ecology, including descriptions of a number of new taxa (Chambers and Woodham 2003; Kirkegaard 2001; Parapar 2003, 2006; Sanfilippo 2001; Sigvaldadóttir 2002).

Examination of further polychaete material collected during those expeditions revealed the presence of nine species of the family Opheliidae: three had been reported from the area before (Ophelia limacina, Ophelina cylindricaudata, and $O$. acuminata), four are new for Icelandic waters (Ammotrypanella cf. arctica McIntosh, 1878, Ophelina abranchiata (Støp-Bowitz,1948), $O$. helgolandica Augener, 1912, and Tachytrypane jeffreisii McIntosh, 1878), and two are described as new to science below (Ophelina basicirra sp. nov., and $O$. bowitzi sp. nov.).

\section{Material and methods}

This study is based on material collected by several oceanographic expeditions within the BIOICE project (Fig. 1a). Specimens were fixed in $4 \%$ formaldehyde-seawater solution buffered with borax, and preserved in $70 \%$ ethanol. Animals were picked from samples by the staff at the Sandgerði Marine Centre (SMC), Iceland, and then identified at species level by the authors.
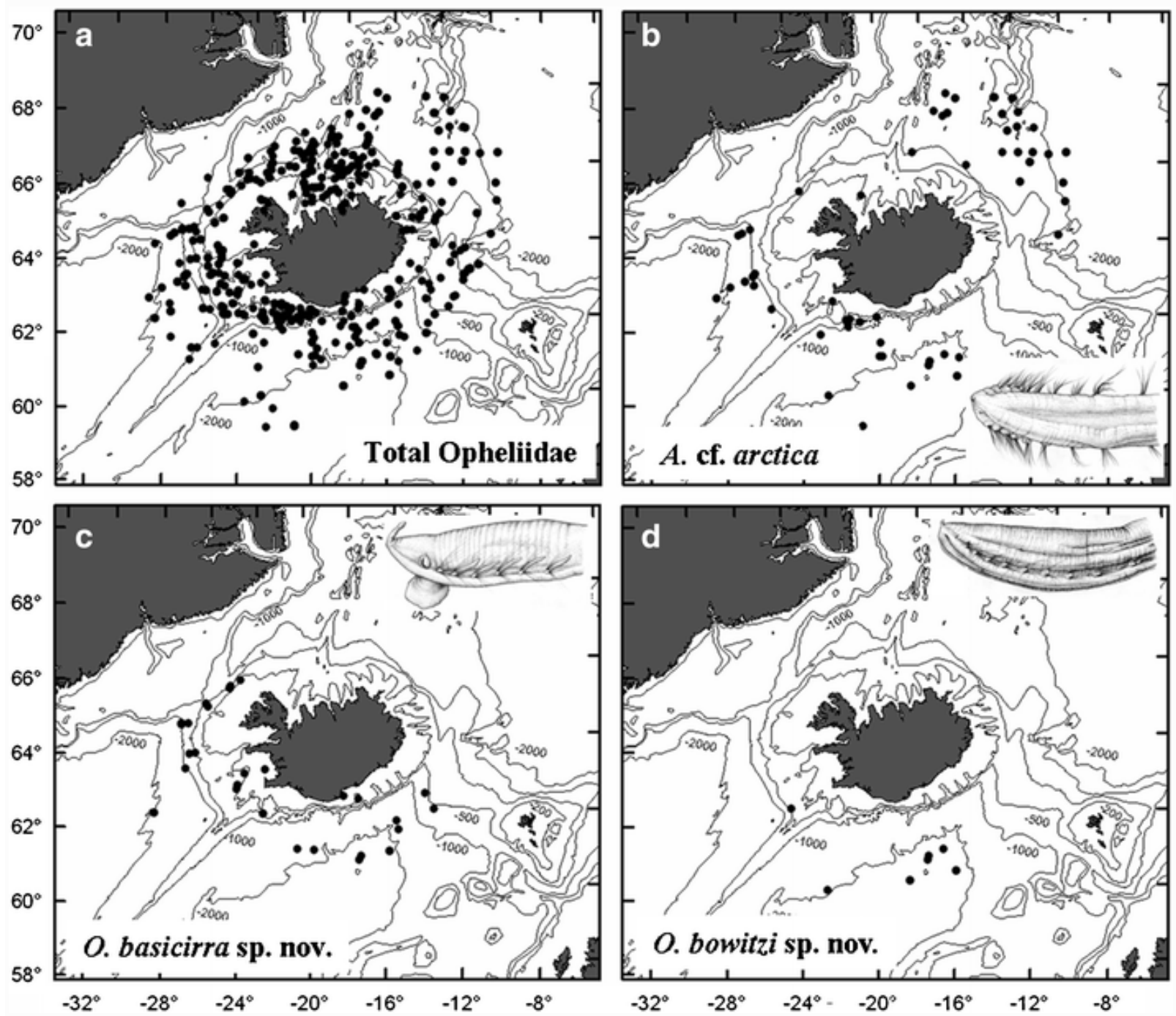

Fig. 1 Maps of the study area and collecting sites of samples including specimens of Opheliidae.a All samples combined. bAmmotrypanella cf. arctica McIntosh. cOphelina basicirra sp. nov. dOphelina bowitzi sp. nov 
Most of the material examined, including most of the type series of the new species, is deposited in the collections of the Icelandic Museum of Natural History, Reykjavik (IMNH); some paratypes are deposited in the Museo Nacional de Ciencias Naturales de Madrid, Spain (MNCN). For comparisons, specimens of selected species were studied from MNCN and the following two Swedish institutions: GNHM = Göteborgs Naturhistoriska Museum, Gothenburg; SMNH = Swedish Museum of Natural History, Stockholm.

For data on the BIOICE samples with opheliid specimens (collecting date, geographical coordinates and depth at the start of the sampling tow, and bottom water temperature), see theElectronic Supplementary Material in the online version of this paper. Additional information on all BIOICE samples (sampling gear used, geographical coordinates at the end of the tow, bottom type) are available from the authors $(\mathrm{GVH})$ upon request.

Specimens used for examination with scanning electron microscopy (SEM) were dehydrated in a graded ethanol series, prepared by critical-point drying using $\mathrm{CO}_{2}$, mounted on aluminium stubs, covered with gold in a BAL-TEC SCD 004 evaporator, and examined and photographed under a JEOL JSM-6400 scanning electron microscope at the Servicios de Apoio á Investigación (SAI), University of A Coruña-UDC, Spain. Species are characterized in this paper according to morphological characters, i.e. according to a morphological species concept.

\section{Results on individual taxa}

A total of 11912 specimens of polychaetes belonging to the family Opheliidae Malmgren, 1867 were sorted from 445 BIOICE samples on both sides of the GIF Ridge (Fig. 1A; Electronic Supplementary Material). They have been assigned to four genera and nine species. Remarks on the taxonomy and distribution of these taxa around Iceland are presented and discussed.

Genus Ammotrypanella McIntosh,1878

Ammotrypanella cf. arctica McIntosh,1878

(Figs. 1b, 2 and 3)

?Ammotrypanella arctica McIntosh-McIntosh (1878: 505); Hartman (1959: 429); Hartman and Fauchald (1971: 132); Glasby and Read (1998: 363); Schüller (2008: 57). Not Fauvel (1914: 246), Levenstein (1978: 81), Kirkegaard (1996: 68); see remarks below.

Or ?Ammotrypanella cirrosa Schüller—Schüller (2008: 57); see remarks below.

\section{Material examined}

BIOICE material: 2326 specimens (19.53\% of Opheliidae) in 62 samples (see Electronic Supplementary Material).

\section{Description}

Specimens 6-15 mm long, 0.5-1.0 mm wide, with 33-38 chaetigers. Prostomium conical with short palpode and nuchal organs as narrow lateral grooves (Figs. $2 \mathrm{a}$ and $3 \mathrm{a}, \mathrm{b}$ ). Eight to ten anterior segments comparably short, with button-shaped parapodia provided with two rows of long stiff chaetae arranged in bushy fascicles (Figs. 2a and 3a). Mid-body segments longer (Fig. 3c); parapodia 
located in a more or less distinct lateral groove and provided with dorsal (notopodial) and ventral (neuropodial) bundles of long capillary chaetae, notopodial chaetae larger. Chaetae arranged in two rows (Fig. 3d). Branchiae of similar lengths, flat, deciduous, hardly tapering to top, present in 5-6 chaetigers preceding the 8-10 posteriormost abranchiate segments. The latter segments reduced in length and close to each other. Pygidium with anal tube about same length as posterior abranchiate region; provided with a deciduous anal cirrus and terminal anus (Figs. $2 \mathrm{~b}$ and 3e, f).

\section{Occurrence}

Ammotrypanella cf. arctica was found around Iceland in wide respective ranges of depth (172$3003 \mathrm{~m})$ and temperature $\left(-0.90-7.3^{\circ} \mathrm{C}\right)$, although most of the samples were collected below $1000 \mathrm{~m}$ (Fig. 1b).

\section{Previously reported distribution}

Originally described by McIntosh (1878) from off Davis Strait, west coast of Greenland, $A$. arctica was later recorded off the coast of New England by Hartman and Fauchald (1971), and from New Zealand by Glasby and Read (1998). Kirkegaard (1996) mentioned this species in the Pacific Ocean, but this record is not accepted here (see Remarks section below). Schüller (2008) later reported A. arctica from the Antarctic Peninsula and proposed a bipolar, if not cosmopolitan, distribution for this species. The present record is the first from Icelandic waters.
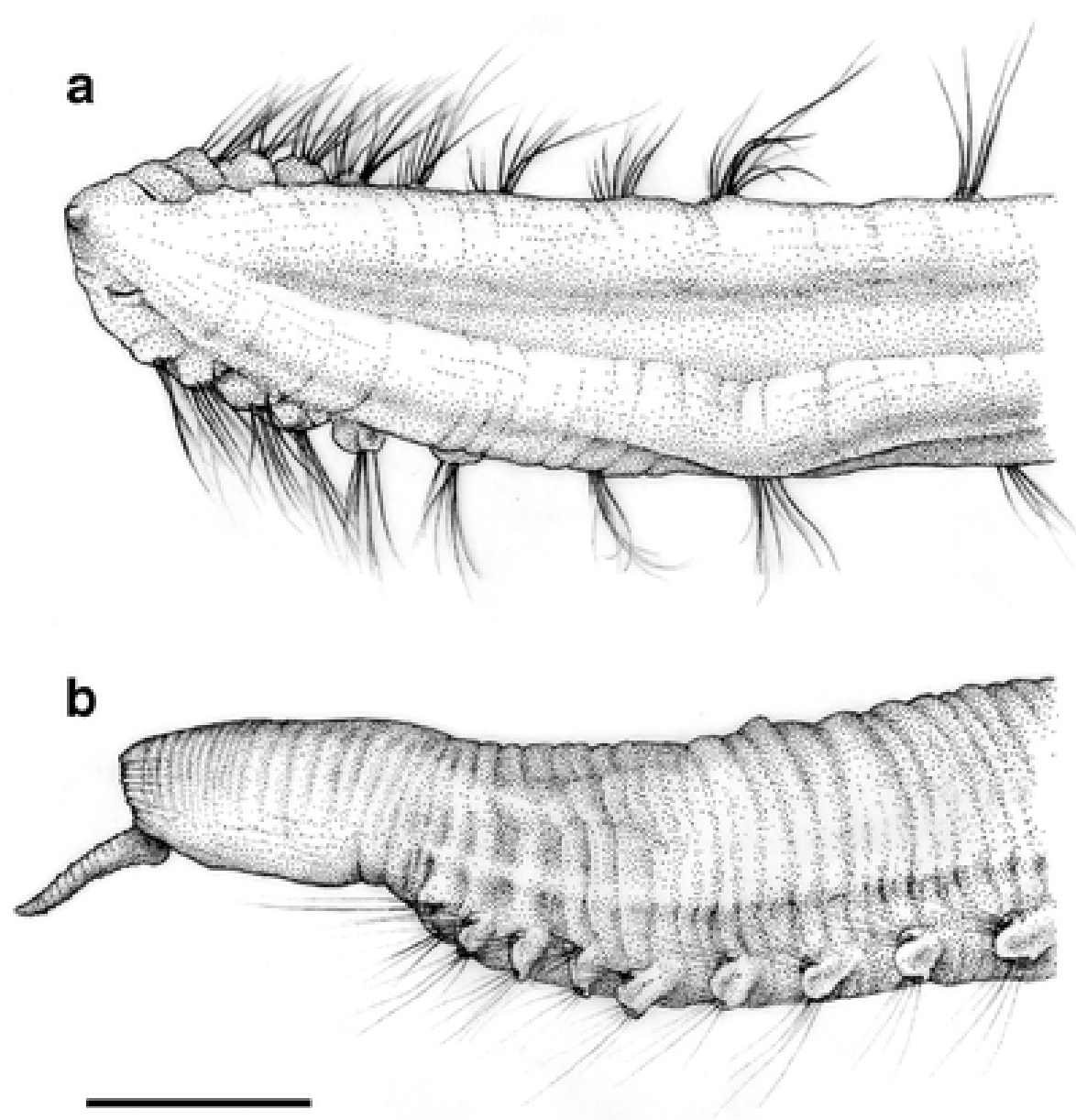

Fig. 2 Ammotrypanella cf. arctica McIntosh (IMNH 24326).

a Anterior end, dorsal view.

bPosterior end, lateral view. Scale bar: $0.5 \mathrm{~mm}$ 


\section{Remarks}

There has been some confusion in the diagnosis of the genus Ammotrypanella and that of its type species, $A$. arctica, due to the short description and drawings by McIntosh (1878). Støp-Bowitz (1945) proposed that Ammotrypanella should be considered as synonymous withOphelina. Fauchald (1977) treated Ammotrypanella as a valid genus characterized by having the branchiae limited to the posterior part of body. However, he also stated that the anal tube has two ventral cirri, which has been proven incorrect. Schüller (2008) revised the type material of A. arctica and confirmed the presence of branchiae in the posterior quarter of the body only. She pointed out that records attributed to this
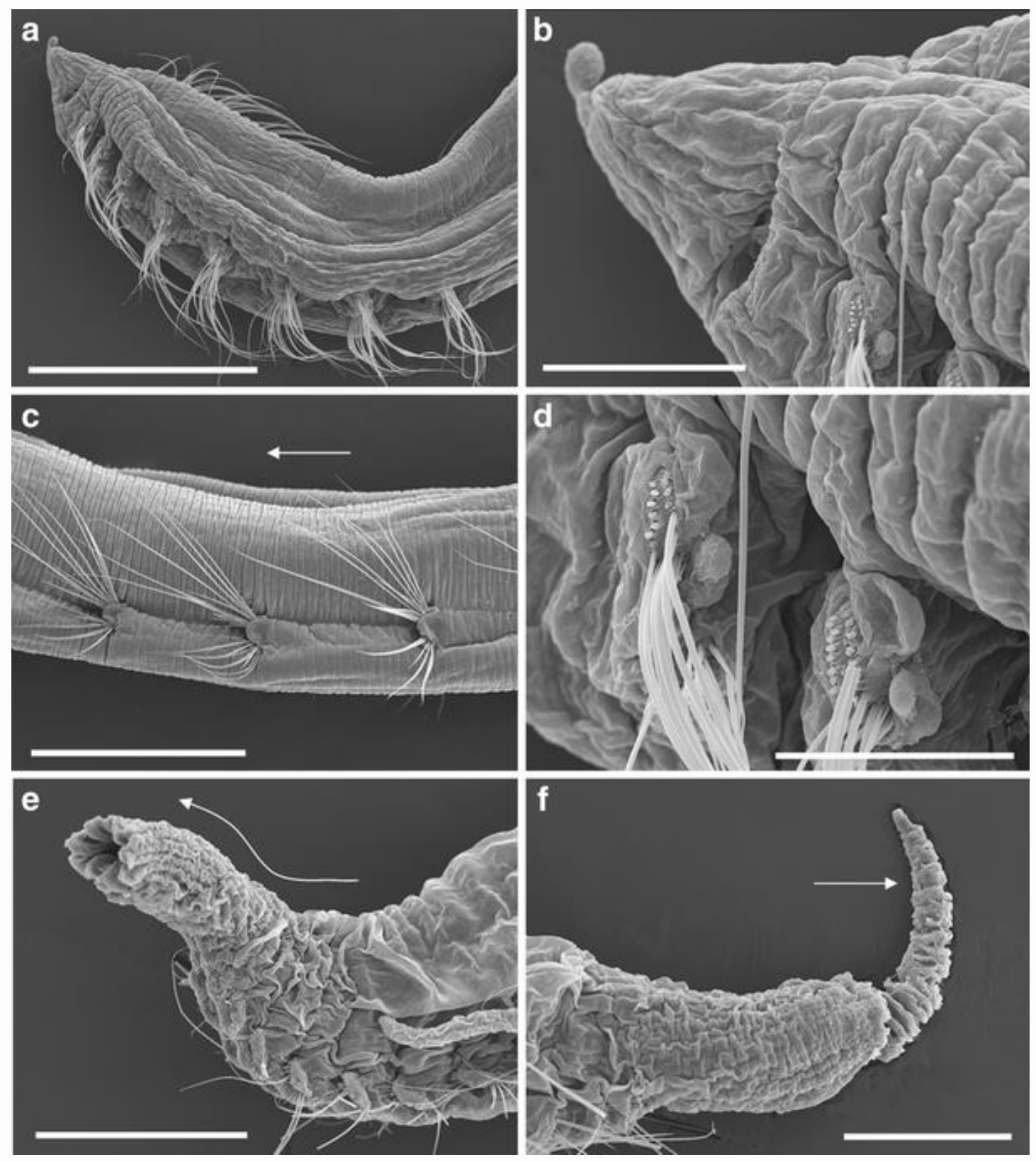

Fig. 3 Ammotrypanella cf. arctica McIntosh (IMNH 24327, BIOICE sample 3648). a Anterior end, dorsal view. b Detail of prostomium and first chaetiger. c First and second chaetigers. d Chaetigers 14-16; arrow points to posterior. e Posterior end, lateral view, anal cirrus lost; shape of arrow reflects typical S shape of posterior body region. f Anal tube, dorsal view, arrow: anal cirrus. Scale bars: (a) $800 \mu \mathrm{m}$; (b, d) $100 \mu \mathrm{m}$; (c) $500 \mu \mathrm{m} ;(\mathbf{e}) 300 \mu \mathrm{m}$; (f) $200 \mu \mathrm{m}$ 
species by Fauvel (1914) and Levenstein (1978) were wrong, because in these authors' material branchiae are present from the first chaetigers; the latter condition does not even agree with the diagnosis of Ammotrypanella (see remarks under Ophelina bowitzi sp. nov. below). The record from the Pacific Ocean by Kirkegaard (1996), not mentioned by Schüller (2008), likely is also wrong and represents a species ofOphelina instead, since Kirkegaard had accepted as valid the description under the name A. arctica by Fauvel (1914). On the other hand, we do not follow Sene-Silva (2007) in rejecting the report by Hartman and Fauchald (1971) of A. arctica in North American Atlantic waters, because Sene-Silva did not present any valid argument to support his conclusions.

The BIOICE specimens of $A$. cf. arctica agree well with the description and drawings by Schüller (2008), except for the presence in the Icelandic specimens of an anal cirrus associated with the opening of the anal tube, a presence denied by Schüller (2008). The presence of a cirrus on the anterior margin of the anal tube was used by Schüller (2008) to propose a different species,Ammotrypanella cirrosa. Schüller (2008) described this as very similar to A. arctica but differing in the presence of more flattened and robust branchiae. Moreover, she characterized a third species, A. mcintoshi Schüller, 2008, as lacking the anal tube. From our point of view, and in accordance with Blake (2000) and Maciolek and Blake (2006), the presence/absence of anal tube or anal cirrus should be used cautiously in the discrimination of species, since those structures can be detached from the body during the sampling and sorting of the material. This does not necessarily mean that Schüller's species are taxonomically invalid, but in our opinion other, more reliable characters should be found to establish (new) species in this genus.

\section{Genus Ophelia Savigny,1822}

\section{Ophelia limacine (Rathke,1843)}

Ammotrypane limacina Rathke—Rathke (1843: 190); Hartman (1959: 428).

Ophelia limacina (Rathke)—McIntosh (1878: 505); McIntosh (1908: 375); Southern (1914: 11); Hartman (1938: 107); Wesenberg-Lund (1951: 83); Tebble (1952: 561); Tebble (1953: 362).

\section{Material examined}

BIOICE material: 37 specimens $(0.31 \%$ of Opheliidae) in three samples (see Electronic Supplementary Material).

\section{Occurrence}

This species was found in shallow (20-30 $\mathrm{m}$ depth) and warm $\left(7.23^{\circ} \mathrm{C}\right.$ bottom temperature) waters off northwestern fjords of Iceland.

\section{Previously reported distribution}

Ophelia limacina was originally described from off the Norwegian coast and has been reported from Arctic seas to the northeast Atlantic (North Sea, English Channel, Atlantic coasts of France and Spain) (e.g. Fauvel 1927; Parapar et al. 1996; Tebble 1952). Hartman (1938, 1969) recorded it from California, but Blake (2000) pointed out that such reports from American Pacific coasts likely correspond instead to either $O$. assimilis Tebble, 1953 or $O$. pulchellaTebble, 1953. In Icelandic waters, O. limacina was first recorded by Wesenberg-Lund (1951). 


\section{Genus Ophelina Örsted 1843}

Örsted (1843) erected Ophelina when describing O. acuminata from Danish coasts. The number of species included in the genus is far from well established. Fauchald (1977) recognized 44 valid species, Sene-Silva (2007) 32, and Sardá et al. (2009) 60. In any case, Ophelina is probably the most diverse genus of the family Opheliidae in waters of the continental shelf and slope, especially since Ammotrypane Rathke has been synonymised withOphelina (see Maciolek and Blake 2006 for an extensive review of the literature).

In NEAW, 16 species were reported prior to the present study: $O$. acuminata Örsted 1843,Ophelina cylindricaudata (Hansen, 1878), $O$.

ingebrigtsenii Kükenthal, 1887, $O$. opisthobranchiata Wirén, 1901, O. kükenthali (McIntosh, 1908), O. helgolandica Augener1912, O. breviata (Ehlers, 1913), O. norvegica Støp-Bowitz, 1945, O. abranchiata Støp-Bowitz,1948, O. groenlandica Støp-Bowitz 1948, O. nybelini (Eliason, 1951), O. $\quad$ modesta Støp-Bowitz,1958, O. sarsi (Eliason, 1962), O. cylindricaudata minima Hartmann-Schröder (1974), O. delapidans longicephala Hartmann-Schröder, 1977 and $O$. margaleffi Sardá et al., 2009. Of these, only $O$. breviata was not originally described from a European coast. Two additional species are described below: $O$. basicirra sp. nov. and $O$. bowitzi sp. nov. All these species are typical for the continental shelf and slope, and are replaced at shallower bottoms by members of other genera such as Ophelia, Armandia Filippi, 1861, and Polyophthalmus Quatrefages, 1850.

As in Ammotrypanella, the shape of the anal tube, or anal funnel, is one of the most relevant taxonomic characters but must be used with similar caution, because the tube breaks off easily when specimens are handled inappropriately (Blake 2000; Maciolek and Blake 2006). Therefore, it is conceivable that any species described from a small number of specimens could have been characterized incorrectly as lacking the anal tube, if the latter had been lost on those specimens.

As a first step towards a future revision of Ophelina, the following sections present the status of each species found in Icelandic waters, a review of all species described or reported in NEAW, and a key to the species currently accepted as valid.

\section{Ophelina abranchiata (Støp-Bowitz,1948)}

(Figs. 4 and 9a)

Ophelia abranchiata Støp-Bowitz-Støp-Bowitz (1948: 22).

Ophelina abranchiata (Støp-Bowitz)—Eliason (1962: 73); Hartman (1965: 186); Parapar and Moreira (2008: 121).

Ophelina farallonensis Blake-Blake (2000: 159; fide Sene-Silva 2007).

\section{Material examined}

BIOICE material: 3697 specimens (31.04\% of Opheliidae) in 213 samples (see Electronic Supplementary Material).

Comparative material: 256 specimens (MNCN 16.01/11347), DIVA-Artabria 2002, sample EBS-400. 


\section{Occurrence}

This species was found around Iceland at respective wide ranges of depth $(116-2400 \mathrm{~m})$ and temperature $\left(-0.86-7.92^{\circ} \mathrm{C}\right)$.

Previously reported distribution

Ophelina abranchiata was originally described from Greenland and subsequently reported from both sides of the North Atlantic (western coasts: Rowe et al. 1982 in Levin and Gooday2003; Volckaert 1987; eastern coasts from Spitsbergen to the Iberian Peninsula: Hansson 1998;
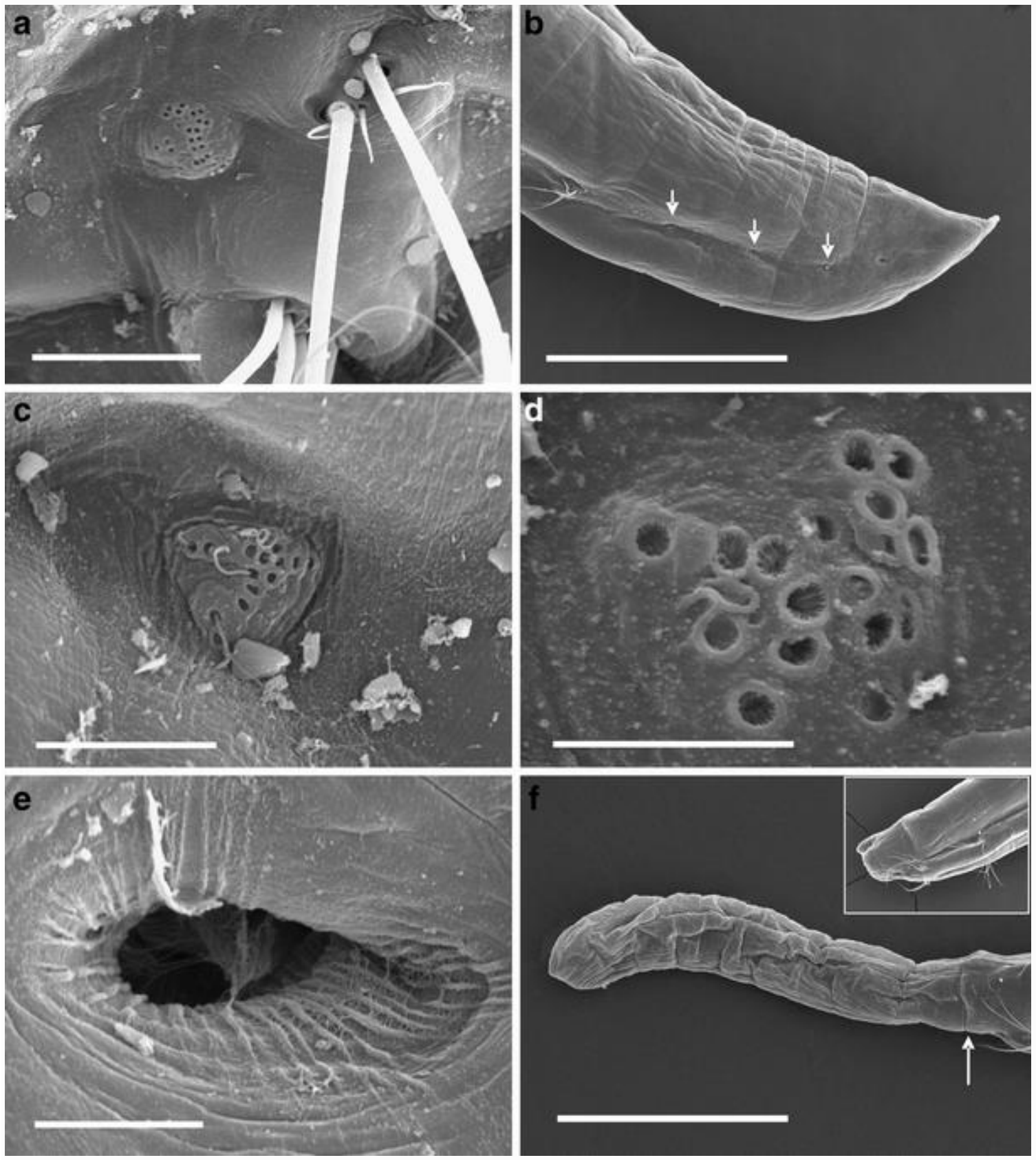

Fig. 4 Ophelina abranchiata (Støp-Bowitz) (IMNH 24328, BIOICE sample 3219). a Mid-body chaetiger. b Anterior end, lateral view; arrows mark positions of lateral organs of first achaetigerous segments. c Lateral organ of an achaetigerous anterior segment. d Detail of lateral organ. e Nuchal organ. f Anal tube; arrow shows breakline; insert: detail of posterior end without anal tube. Scale bars: (a) $20 \mu \mathrm{m}$; (b) $600 \mu \mathrm{m}$; (c, e) $10 \mu \mathrm{m}$; (d) $5 \mu \mathrm{m}$; (f) $900 \mu \mathrm{m}$ 
Kirkegaard 1996; Parapar and Moreira 2008; Weslawski et al. 2003). Kröncke (1998) recorded the species in the Eurasian Arctic Ocean, Castelli et al. (1995) in the Mediterranean Sea, and Borowski and Thiel (1998) and Borowski (2001) in the southeast Pacific Ocean.

\section{Remarks}

Sene-Silva (2007) proposed Polyophthalmus translucens Hartman, 1960 and Ophelina farallonensis Blake, 2000, both described from California, as junior synonyms of $O$. abranchiata. Blake (2000) had separated $O$. farallonensis from $O$. abranchiata according to only one character: $O$. farallonensis bears a long anal tube provided with a simple anal cirrus, whereas $O$. abranchiata bears a short anal tube provided with two terminal lobes (see Fig. 7.6 in Blake 2000 for $O$. farallonensis, and Fig. 7 in Støp-Bowitz 1948 for $O$. abranchiata). Although we have not examined the type material of either species, we support the synonymy of $O$. farallonensis with $O$. abranchiata proposed by Sene-Silva (2007), because the only separating character proposed by Blake (2000) probably resulted from a misinterpretation of the posterior end in the examined specimens. Thus, Blake (2000) did not realize that the original description of O. abranchiata by Støp-Bowitz (1948) corresponds to a specimen without anal tube.

Examination of some specimens under SEM has revealed the presence of a ciliated area, i.e. the lateral organ, between the notopodium and the neuropodium in all chaetigerous segments (Fig. 4a), as well as in the anterior segments of the body which are achaetigerous and apparently devoid of parapodia (Fig. 4b, c). The number of lateral organs suggests the presence of three anterior segments between the peristomium and the first chaetigerous segment. Parapar and Moreira (2008) previously reported this feature for Iberian specimens. The ultrastructure of the lateral organs shows several ribs within the cuticular opening (Fig. 4d) very alike to those reported by Sardá et al. (2009) for Ophelina margaleffi. The nuchal organ is a simple opening lacking a posterior lappet (Fig. 4e), which is very different from the conditions in species such as $O$. basicirra sp. nov., $O$. helgolandica, and $O$. bowitzi sp. nov. The anal tube is elongate (Fig. 4f), very delicate and easily detachable, thus lacking from many specimens examined (Fig. 4f, insert). In fact, $O$. abranchiata was originally described erroneously as without anal tube (Støp-Bowitz 1948; see present Fig. 9a), but that mistake has been corrected by Eliason (1962: fig. 20c).

Ophelina acuminata Örsted, A. S 1843

Ophelina acuminata Örsted—Örsted(1843: 46); Parapar and Moreira (2008: 122).

Ammotrypane aulogaster Rathke-Rathke (1843: 186); McIntosh (1878: 505); McIntosh (1908: 383); Kükenthal (1887: 148); Southern (1914: 11); Eliason (1951: 135).

Ammotrypane ingebrigtsenii Kükenthal—Kükenthal (1887: 371; fide Hartman 1959).

\section{Material examined}

BIOICE material: 589 specimens (4.94\% of Opheliidae) in 61 samples (see Electronic Supplementary Material).

\section{Occurrence}

This species was found along Iceland in a wide range of temperatures $\left(-0.54-8.59^{\circ} \mathrm{C}\right)$, but never below the $600 \mathrm{~m}$ isobath (depth range: $46-584 \mathrm{~m}$ ). 
This species was originally described from the coast of Denmark and has frequently been reported in all oceans (e.g. Day 1961, 1967; Elías et al. 2003; Hartmann-Schröder 1979; Salazar-Vallejo and Londoño-Mesa 2004; Uebelacker 1984; Wehe and Fiege 2003); However, Elías et al. (2003) questioned the consideration as a cosmopolitan (e.g. Hartman and Fauchald1971; Uebelacker 1984) because of clear differences between the type material and the descriptions from other latitudes. The species was previously recorded in Icelandic waters by Wesenberg-Lund (1951).

\section{Ophelina basicirrasp. nov.}

(Figs. 1c, 5, 6, 7 and 8)

\section{Etymology}

The species epithet refers to the location of the characteristic anal cirrus in the ventral-proximal part of the anal tube. It is to be treated as an adjective for the purposes of nomenclature.

\section{Material examined}

BIOICE material: 299 specimens (2.51\% of Opheliidae) in 34 samples (see Electronic Supplementary Material), as follows. Holotype (Icelandic Museum of Natural History, IMNH 24314) BIOICE sample 2934DK: North Atlantic Ocean NW of Iceland, bottom tow from $66^{\circ} 00^{\prime} 56^{\prime \prime} \mathrm{N} 26^{\circ} 46^{\prime} 89^{\prime \prime} \mathrm{W}$ to

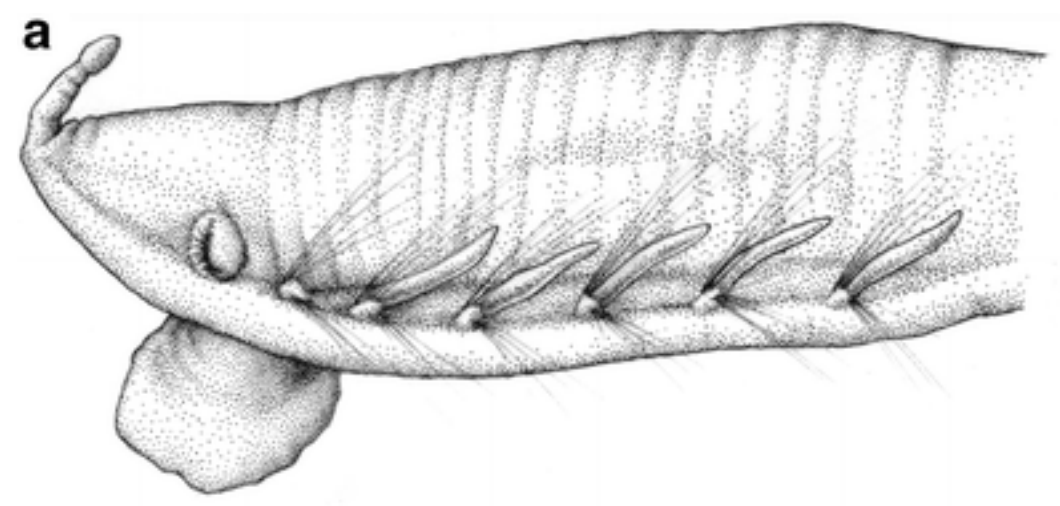

Fig. 5 Ophelina basicirra sp. nov. (holotype, IMNH 24314).

a Anterior end, lateral view.

b Posterior end, lateral view. Scale bar: $0.5 \mathrm{~mm}$

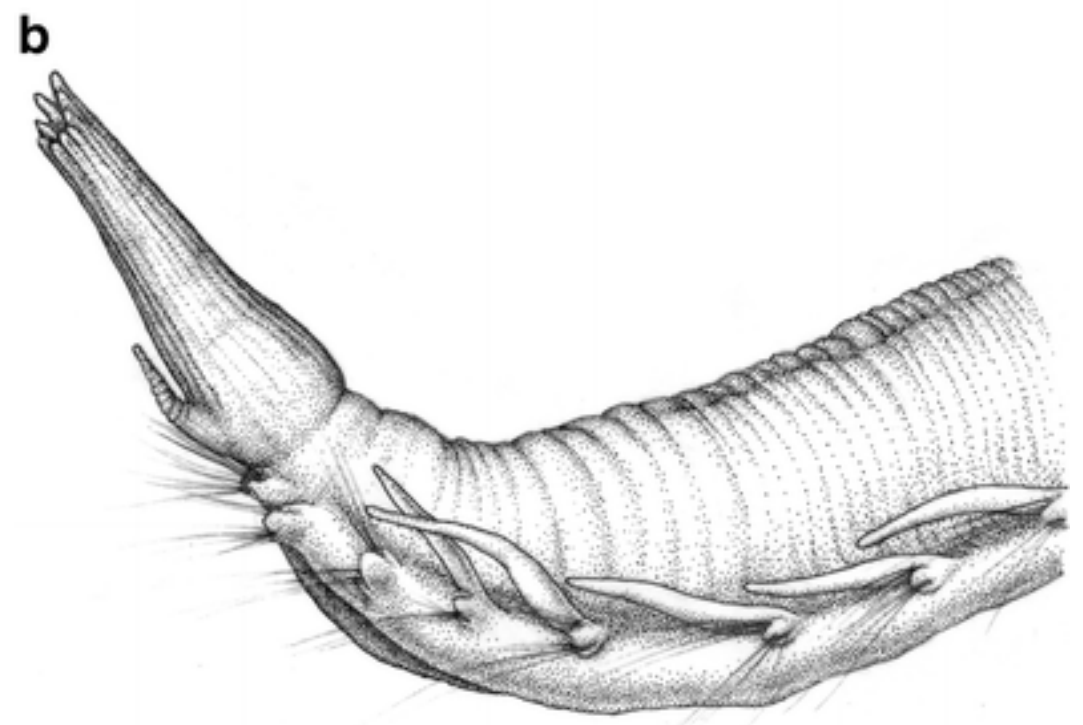


$66^{\circ} 00^{\prime} 91^{\prime \prime} \mathrm{N} 26^{\circ} 46^{\prime} 30^{\prime \prime} \mathrm{W}, 412$ to $405 \mathrm{~m}$ depth, 28 August 1996 , bottom temperature $6.34^{\circ} \mathrm{C}$. 5 paratypes (BIOICE sample 2934DK, IMNH 22315); 4 paratypes (IMNH 24316, BIOICE 2229); 57 paratypes (IMNH 24317-18, BIOICE 2303); 2 paratypes (IMNH 24319, BIOICE 3531-0.5); 5 paratypes (MNCN 16.01/13271, BIOICE 2904).
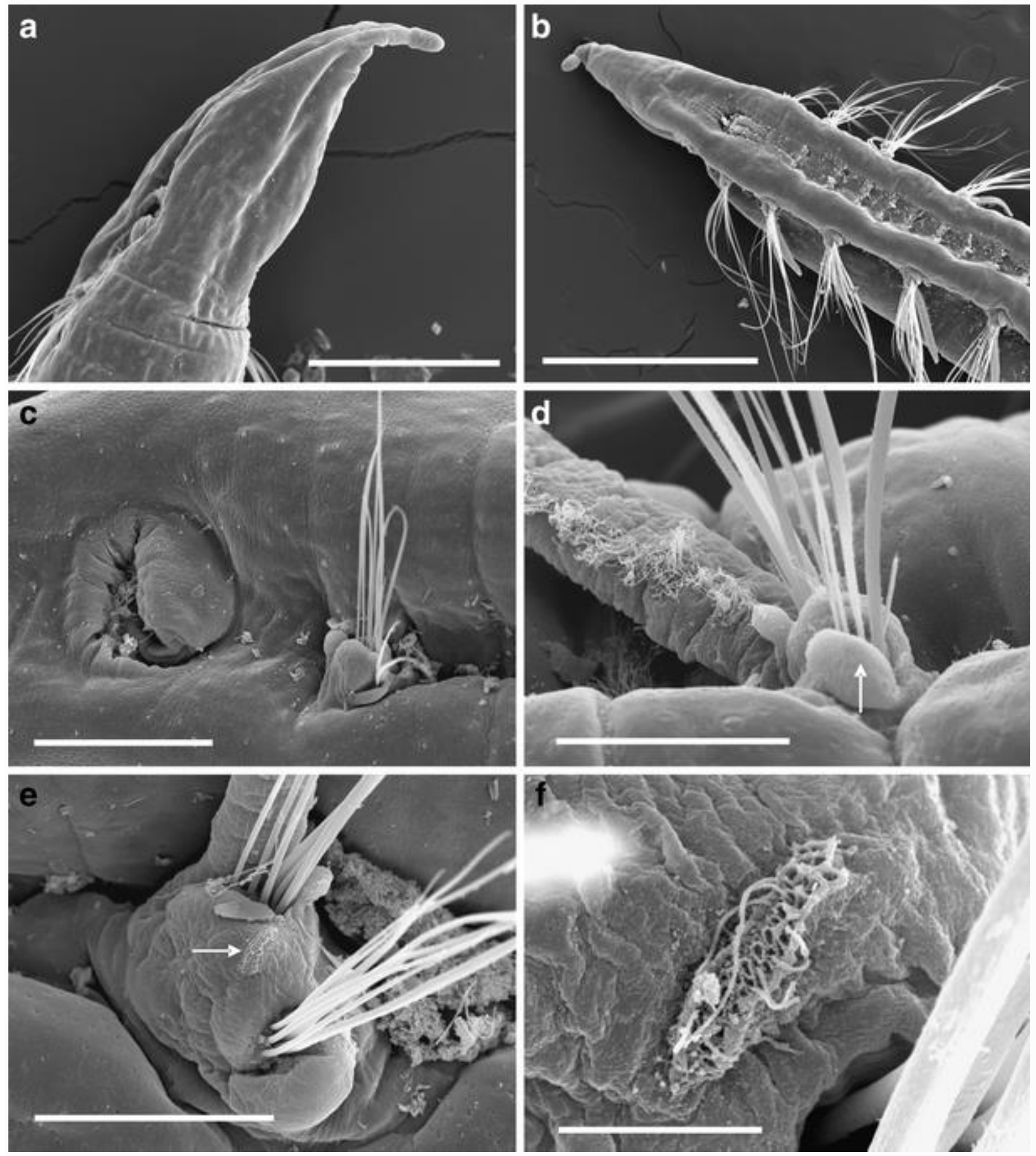

Fig. 6 Ophelina basicirra sp. nov. (paratypes, IMNH 24318, BIOICE sample 2303). a Anterior end, dorsal view. b Anterior end, ventral view. c Nuchal organ and first chaetiger. d Mid-body chaetiger, ventral view; arrow marks position of anterior lobe. $\mathbf{e}$ Mid-body chaetiger, arrow marks position of lateral organ. $\mathbf{f}$ Detail of lateral organ. Scale bars: (a) $200 \mu \mathrm{m}$; (b) $500 \mu \mathrm{m}$; (c) $100 \mu \mathrm{m}$; (d) $50 \mu \mathrm{m}$; (e) $60 \mu \mathrm{m}$; (f) $10 \mu \mathrm{m}$ 
Complementary material (Icelandic Museum of Natural History): 26 specimens (BIOICE sample 2203), 1 spec. (2213-0.5), 3 spec. (2223DK), 4 spec. (2223), 2 spec. (2332-0.5); 21 spec. (2346), 32 spec. (2512), 1 spec. (2514), 1 spec. (2520), 1 spec. (2697), 1 spec. (2823), 2 spec. (2830), 5 spec. (2859), 23 spec. (2860); 6 spec. (2864DK), 3 spec. (2873), 25 spec. (2877), 4 spec. (2901DK), 1 spec. (2903), 1 spec. (2903-0.5), 12 spec. (2904), 33 spec. (2937), 1 spec. (3067DK), 1 spec. (3072), 9 spec. (3073), 6 spec. (3099DK), 5 spec. (3509), 1 spec. (3582DK).

Comparative material: syntype Ophelina nybelini Eliason, 1951 (GNHM Polych. 10999).
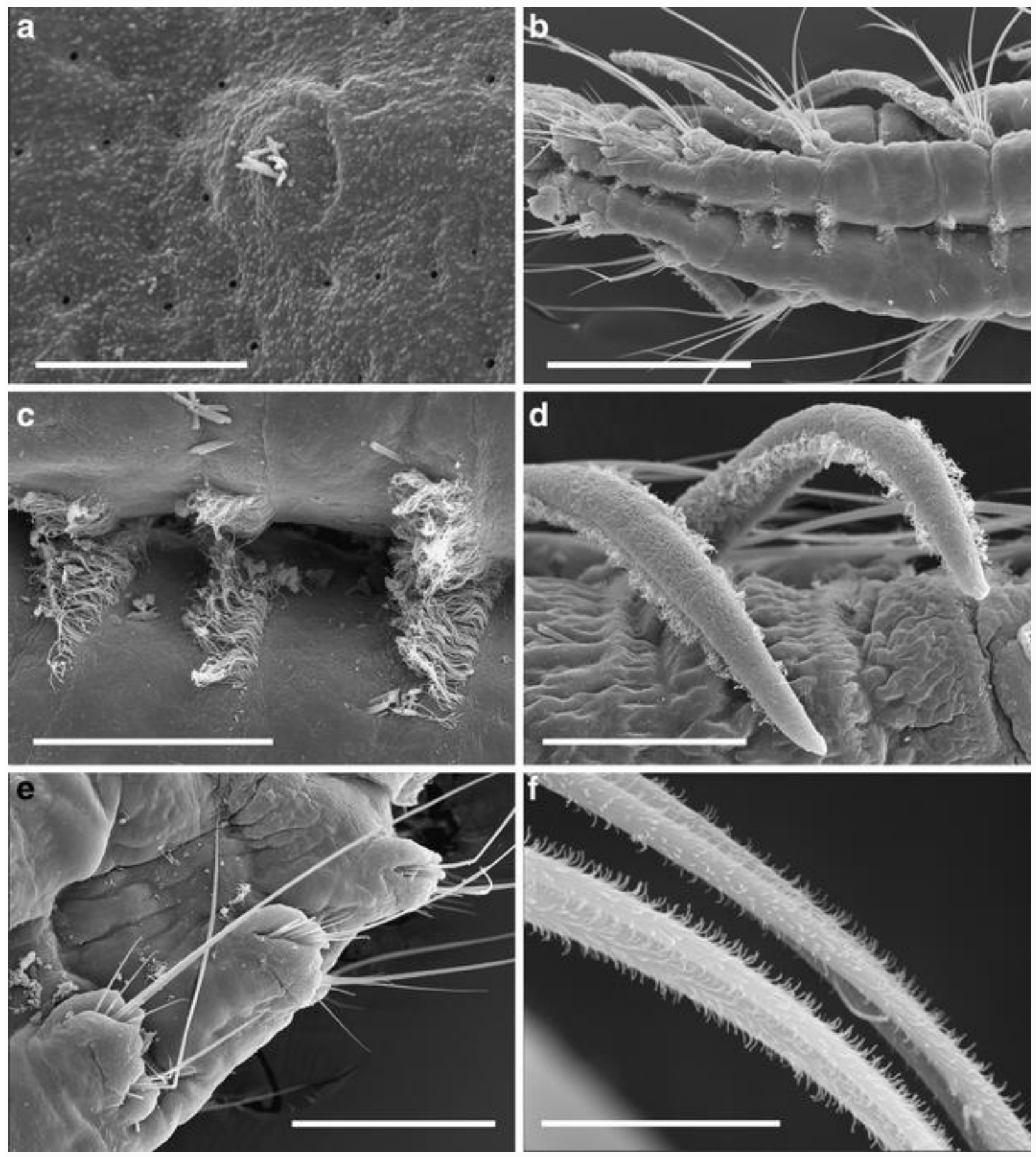

Fig. 7 Ophelina basicirra sp nov. (paratypes, IMNH 24318, BIOICE sample 2303). a Cilia and pores on body surface. b Posterior end, ventral view. c Detail of ciliated ventral transverse bands. d Posterior body chaetigers. e Branchiae. f Detail of hirsute chaetae. Scale bars: (a, f) $10 \mu \mathrm{m}$; (b) $200 \mu \mathrm{m}$; (c) $50 \mu \mathrm{m}$; (d) $90 \mu \mathrm{m}$; (e) $100 \mu \mathrm{m}$ 


\section{Diagnosis}

A small species mostly distinguishable by the presence of a long and narrow anal tube provided with 8-10 short terminal cirri and a short anal cirrus attached at base.

\section{Description (based on holotype)}

Body $8 \mathrm{~mm}$ long and $0.5 \mathrm{~mm}$ wide; fusiform, with 25 chaetigers, deeply grooved both laterally and ventrally. Prostomium long and slender, much longer than wide at base (Figs. 5a and 6a, b), with two
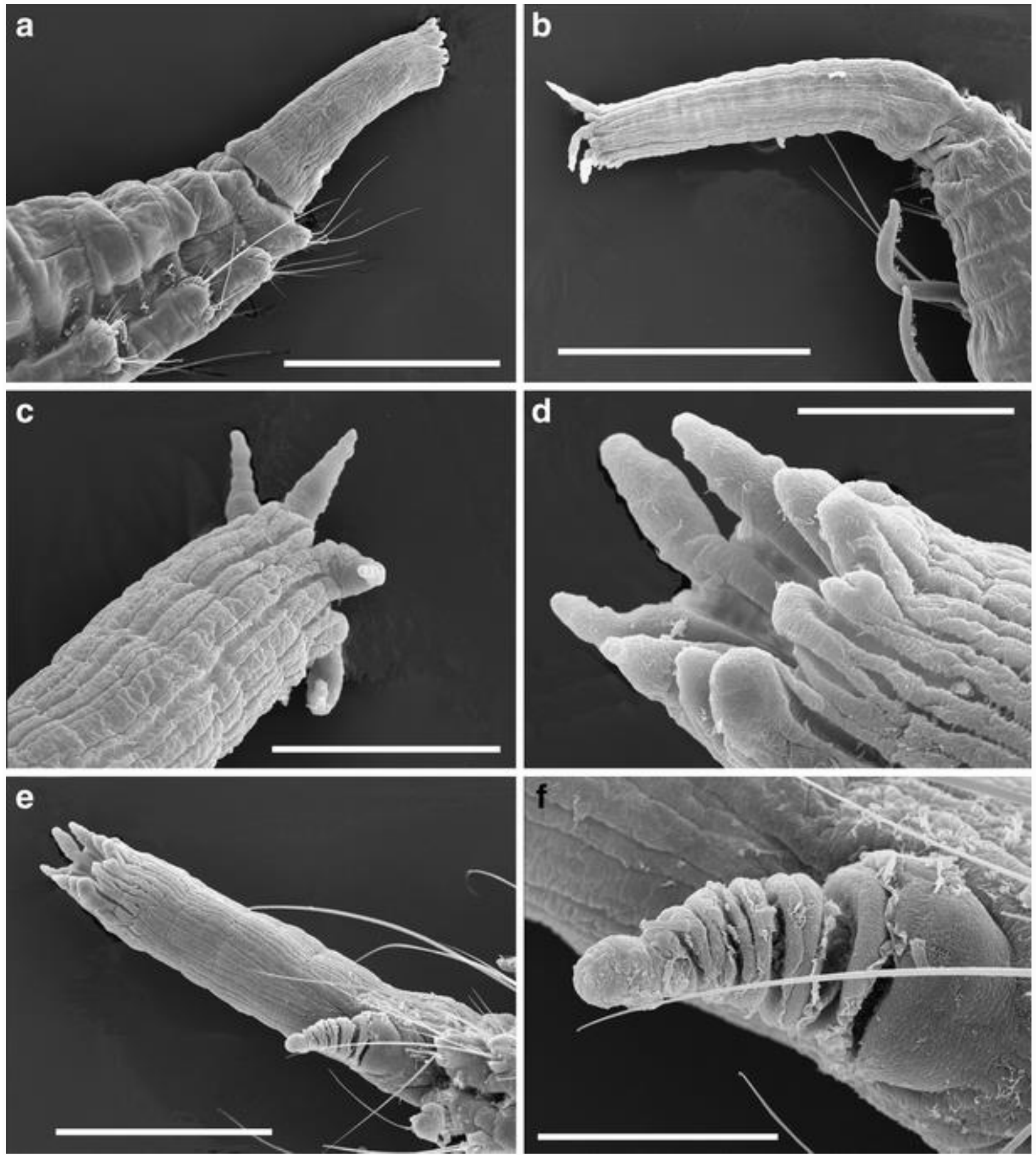

Fig. 8 Ophelina basicirra sp. nov. (Paratypes, IMNH 24318, BIOICE sample 2303). a, bPosterior end with anal tube, lateral views. c, $\mathbf{d}$ Cirri of anal tube. e Anal tube, ventral view. $\mathbf{f}$ Detail of anal cirrus of anal tube. Scale bars: (a, b) $300 \mu \mathrm{m}$; (c) $90 \mu \mathrm{m}$; (d) $50 \mu \mathrm{m}$; (e) $200 \mu \mathrm{m}$; (f) $60 \mu \mathrm{m}$ 
prominent nuchal organs (Figs. 5a and 6c). No eyes observed. Parapodia rounded, with short dorsal cirrus and subulate ventral lobe (Fig. 6d, e). Ciliated lateral organs between dorsal and ventral chaetae bundles (Fig. 6e, f). Body surface provided with ciliated bottoms and cuticle pores (Fig. 7a), ciliated bands segmentally located in ventral body groove (Fig. 7b, c). Branchiae long, cirriform, and provided with two lateral rows of cilia (Fig. 7d); absent in the first (Fig. 6b, c) and last three body chaetigers (Fig. 7e). All chaetae long and hirsute capillaries (Fig. 7f), larger in notopodia. Anal tube as long as last 4 chaetigers (Figs. $5 \mathrm{~b}$ and $8 \mathrm{a}$ ), slender, with $8-10$ short terminal cirri (Fig. 8b-d), and short anal cirrus attached at base (Fig. 8e, f).

\section{Occurrence}

The species has been found south of the GIF ridge (Fig. 1c) at a wide range of depths (23-2298 m) but limited to relatively warm water $\left(2.37-8.68^{\circ} \mathrm{C}\right)$.

\section{Remarks}

The characteristic anal tube and anal cirrus of Ophelina basicirra sp. nov. is not present in any other species of the genus reported from the Boreo-Arctic European seas (see the key below). There are, however, two species which also show an anal cirrus on the base of the anal tube, namely Ophelina nybelini (Eliason, 1951) and O. longicephala Hartmann-Schröder, 1977 (for species status, see below). Both were originally described from European waters but have not been recorded elsewhere since (Bellan 2001; Hansson 1998).

Ophelina nybelini was described by Eliason (1951) from deep waters (4540-4600 m) in the North Atlantic $\left(43^{\circ} 33^{\prime} \mathrm{N} 35^{\circ} 24^{\prime} \mathrm{W}\right.$ to $\left.40^{\circ} 34^{\prime} \mathrm{N} 35^{\circ} 52^{\prime} \mathrm{W}\right)$ and was originally included in the genus Ammotrypane. The anal cirrus in this species (Figs. 9g and 10c) is similar to that in $O$. basicirra sp. nov., but the respective anal tubes are very different. In $O$. basicirra n. sp. it is slender (narrower than the posterior body region) and provided with well defined terminal cirri, whereas in O. nybelini the tube is wider (almost as wide as the posterior body region) and without terminal cirri. Ophelina nybelini shares this kind of anal tube with $O$. bowitzi sp. nov., but the latter lacks the anal cirrus that is characteristic of the former (see also the Remarks under $O$. bowitzi below).

Ophelina longicephala (Fig. 9c) was described by Hartmann-Schröder (1977) from $72 \mathrm{~m}$ depth at the Gorringe Bank off the southern Portuguese coast. It was originally treated as a subspecies of Ophelina delapidans (Kinberg, 1866), from Chile. However, a comparison of the drawings given by Hartmann-Schröder (1977) for "O. delapidans longicephala" with those given by Ehlers (1901) for $O$. delapidans shows that the two taxa are clearly different. Although we have not revised the type material, we propose to consider the Atlantic species as distinct, i.e. under the name Ophelina longicephala Hartmann-Schröder, 1977. In this species the anal cirrus is located ventrally and close to the base of the anal tube, as in $O$. basicirra sp. nov., but differs in being thinner and longer, about as long as the posterior branchiae. In addition, the two species differ in the shape of the anal tube, which is wider, short and ending in numerous ovate cirri inO. longicephala.

The presence of multiple ciliated bands per segment and on the gills, and the hirsute appearance of the capillary chaetae, are very similar to those illustrated by Sardá et al. (2009) for O. margaleffi. This species was described from submarine canyons off the Catalonian coast (western Mediterranean) and was differentiated using characters such as the presence of eyes, the shape and length of chaetae and nuchal organs. However, Parapar and Moreira (2008) argued for synonymy of $O$. margaleffi with $O$. modesta, because the morphological support for differentiating the former is feeble, and the statement that "anal funnel structure is quite similar in both species" (Sardá et 
al. 2009) is incorrect. On the other hand, Fig. 4f in Sardá et al. (2009) shows the anal tube in $O$. margaleffi with large terminal papillae, i.e. different from the anal tube illustrated by Eliason (1962: fig. 20c) in the original description of Ammotrypane sarsi(currently considered as synonymous with $O$. modesta), and from those by Støp-Bowitz (1958: fig. 124) and Parapar and Moreira (2008: fig. $5 \mathrm{C}$ ) for $O$. modesta. Consequently, we now consider the synonymy of $O$. margaleffi with $O$. modesta as doubtful.

\section{Ophelina cylindricaudata (Hansen,1878)}

Ammotrypane cylindricaudatus Hansen-Hansen (1878: 8); McIntosh (1908: 385); Eliason (1951: 135); Pillai (1961: 27); Hartman and Fauchald (1971: 132).

a
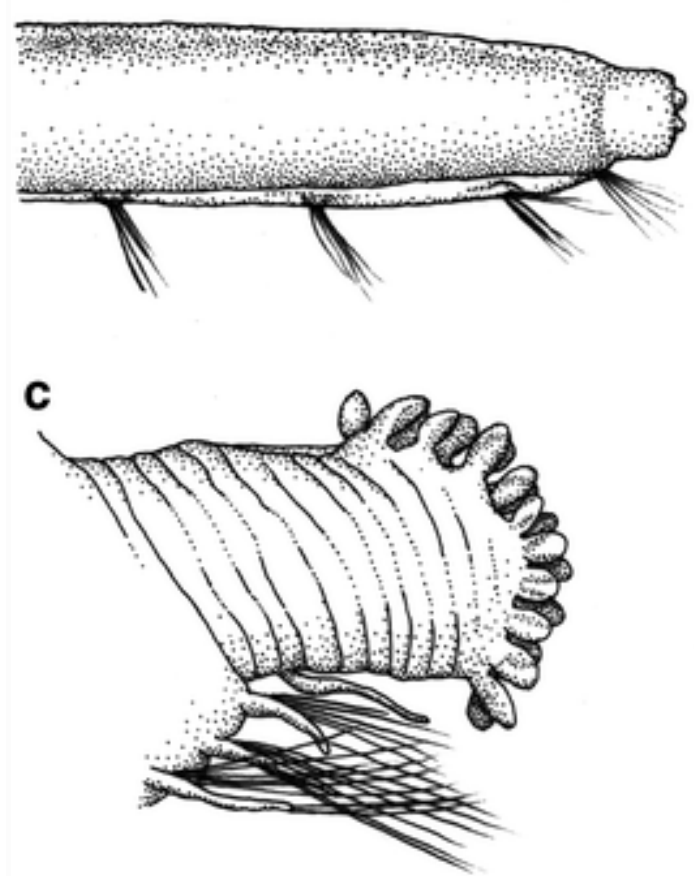

e

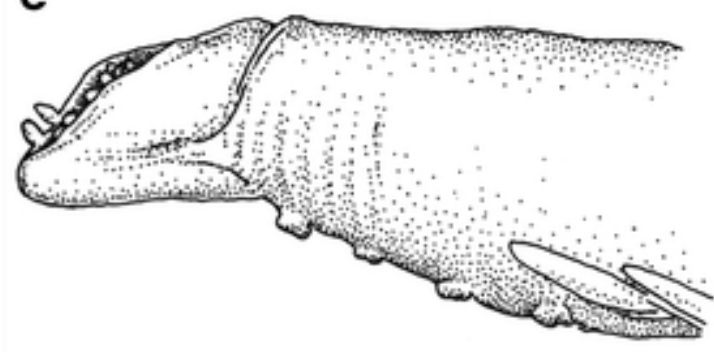

b

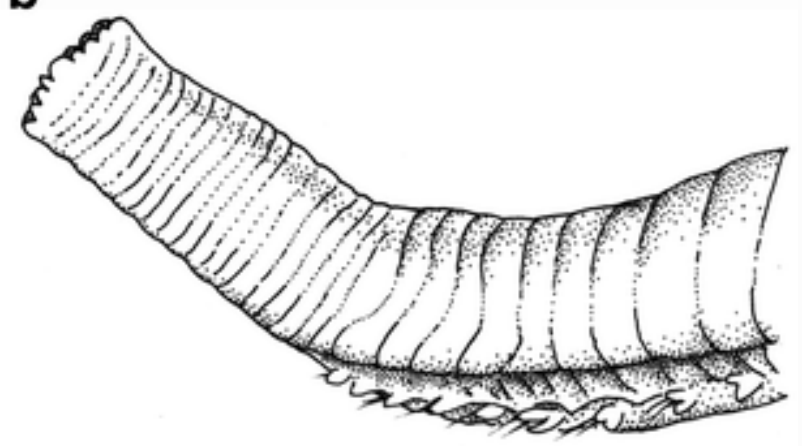

d

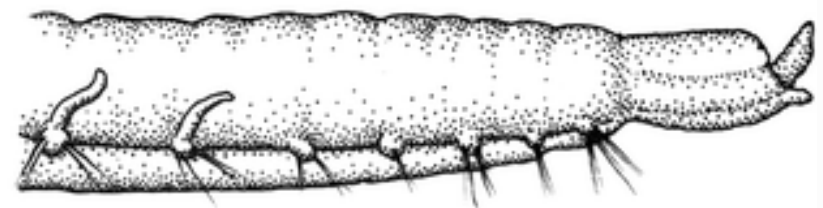

f

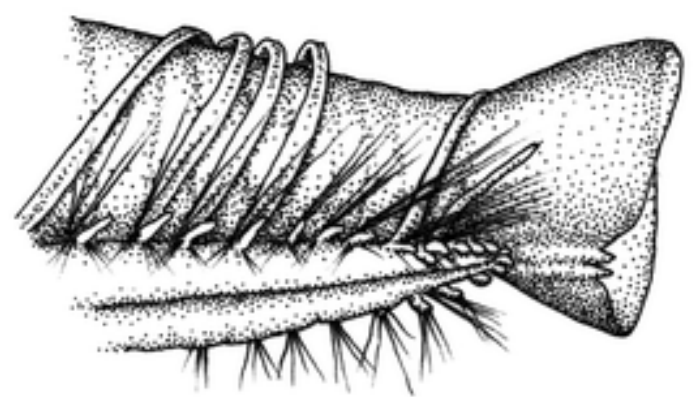

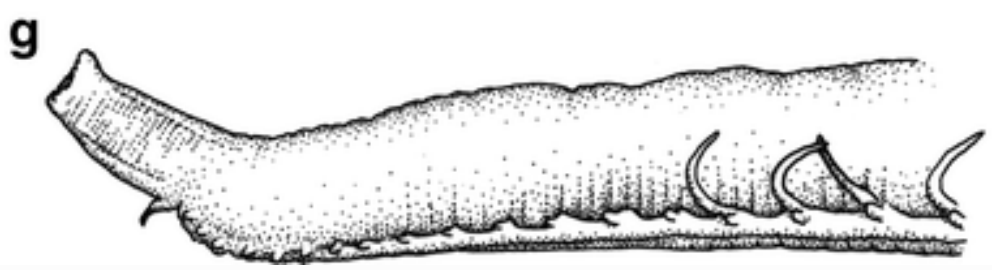

Fig. 9 Posterior body region in some Atlantic Ophelina species (redrawn from originals). a $O$. abranchiata (from Støp-Bowitz 1948). b $O$. bowitzi sp. nov. (from Fauvel 1914, as A. arctica). c O. delapidans longicephala (from Hartmann-Schröder 1977). d O. groenlandica (from Støp-Bowitz 1948). eO. helgolandica (from Augener 1912). f O. norvegica (from Støp-Bowitz 1945). g O. nybelini (from Eliason 1951) 
Ophelina cylindricaudata (Hansen) —Støp-Bowitz (1945: 49); Støp-Bowitz (1948: 18); Day (1973: 96); Salazar-Vallejo and Londoño-Mesa (2004: 40); Maciolek and Blake (2006: 105); Parapar and Moreira (2008: 126).

\section{Material examined}

BIOICE material: 4638 specimens (38.94\% of Opheliidae) in 289 samples (see Electronic Supplementary Material).

Comparative material: 39 specimens (MNCN 16.01/11351), DIVA-Artabria 2002, sample EBS-400

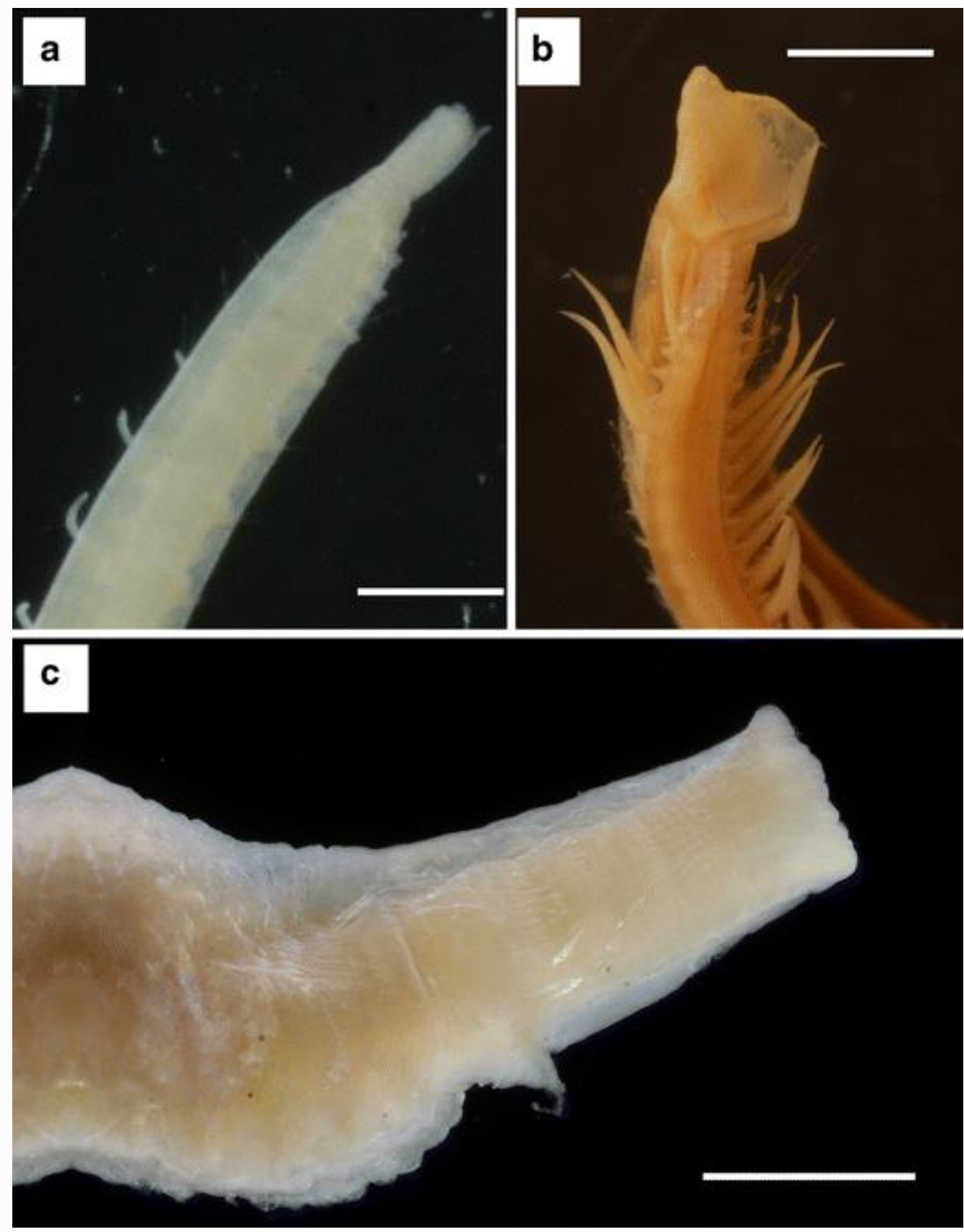

Fig. 10 Posterior body region in three North Atlantic-Arctic species of Ophelina not found in BIOICE samples. a $O . \quad$ groenlandica St $\varnothing \mathrm{p}-B o w i t z, 1948$ (holotype, SMNH T-7831). b O. norvegica St $\varnothing \mathrm{p}-$ Bowitz, 1945 (SMNH 11137). cO. nybelini Eliason, 1951 (syntype, GNHM Polych. 10999). Scale bars: (a) $0.5 \mathrm{~mm} ;(\mathbf{b}, \mathbf{c}) 1 \mathrm{~mm}$ 
This species was found at wide respective ranges of depth $(68-2400 \mathrm{~m})$ and temperature $(-0.86-$ $7.92^{\circ} \mathrm{C}$ ) along the coast of Iceland.

\section{Previously reported distribution}

Ophelina cylindricaudata was described from the coast of Norway and has been reported mostly from Northern-Hemisphere parts of the Atlantic and Pacific oceans and from the Arctic and Antarctic seas (e.g. Hartmann-Schröder 1996; Parapar and Moreira 2008; Salazar-Vallejo and LondoñoMesa 2004; Uebelacker 1984). Maciolek and Blake (2006), following Hartmann-Schröder and Rosenfeldt (1989), expressed doubts as to whether the Antarctic specimens correspond to this species. Ophelina cylindricaudata was previously recorded in Icelandic waters by Wesenberg-Lund (1951).

\section{Remarks}

Uebelacker (1984) reported the presence of branchiae in the middle third of the body in material from the Gulf of Mexico; recently, Parapar and Moreira (2008) found the same character in specimens from the Iberian Peninsula. This could indicate the existence of closely related species with overlapping distribution areas.

\section{Ophelina helgolandica Augener, 1912}

(Figs. 9e and 11)

Ophelina helgolandiae Augener-Augener (1912: 174); Støp-Bowitz (1945: 48); Støp-Bowitz (1948. 17).

Ophelina helgolandica Augener-Hansson (1998: 109); Rowe (2010: 2). See Remarks below.

\section{Material examined}

BIOICE material: 143 specimens (1.20\% of Opheliidae) in 18 samples (see Electronic Supplementary Material).

Comparative material: holotype Ophelina groenlandica Støp-Bowitz, 1948 (SMNH T-7831). 1 specimen Ophelina norvegica Støp-Bowitz, 1945 (SMNH 11137).

\section{Description}

Specimens 14-30 mm long, 1.0-1.8 mm wide, with 30-34 chaetigers. Prostomium conical, with well defined palpode which is apparently articulated (Fig. 11a; see also Augener 1912: fig. 9), and with a nuchal organ provided with a posterior lappet (Fig. 11b). No eyes observed. Parapodia well defined, with minute spherical dorsal cirrus and subulate ventral lobe (Fig. 11c). All chaetae capillaries. Branchiae characteristically abruptly tapered distally (Fig. 11d); size of branchiae increasing from second chaetiger to end of body, last pairs of branchiae substantially smaller (Fig. 11e). First and last three chaetigers lacking branchiae (Fig. 11a, f). A ciliated lateral organ between dorsal and ventral 
chaetae bundles (Fig. 11e). Anal tube short, cylindrical, slightly truncated and obliquely opened towards dorsal part of body (Fig. 11f).

\section{Occurrence}

This species was found along the coast of Iceland, mostly between the $500 \mathrm{~m}$ and $1000 \mathrm{~m}$ isobaths (depth range $562-2710 \mathrm{~m}$ ). Temperature range $-0.77-5.18^{\circ} \mathrm{C}$.

\section{Previously reported distribution}

Spitsbergen (Augener 1912; Hansson 1998).
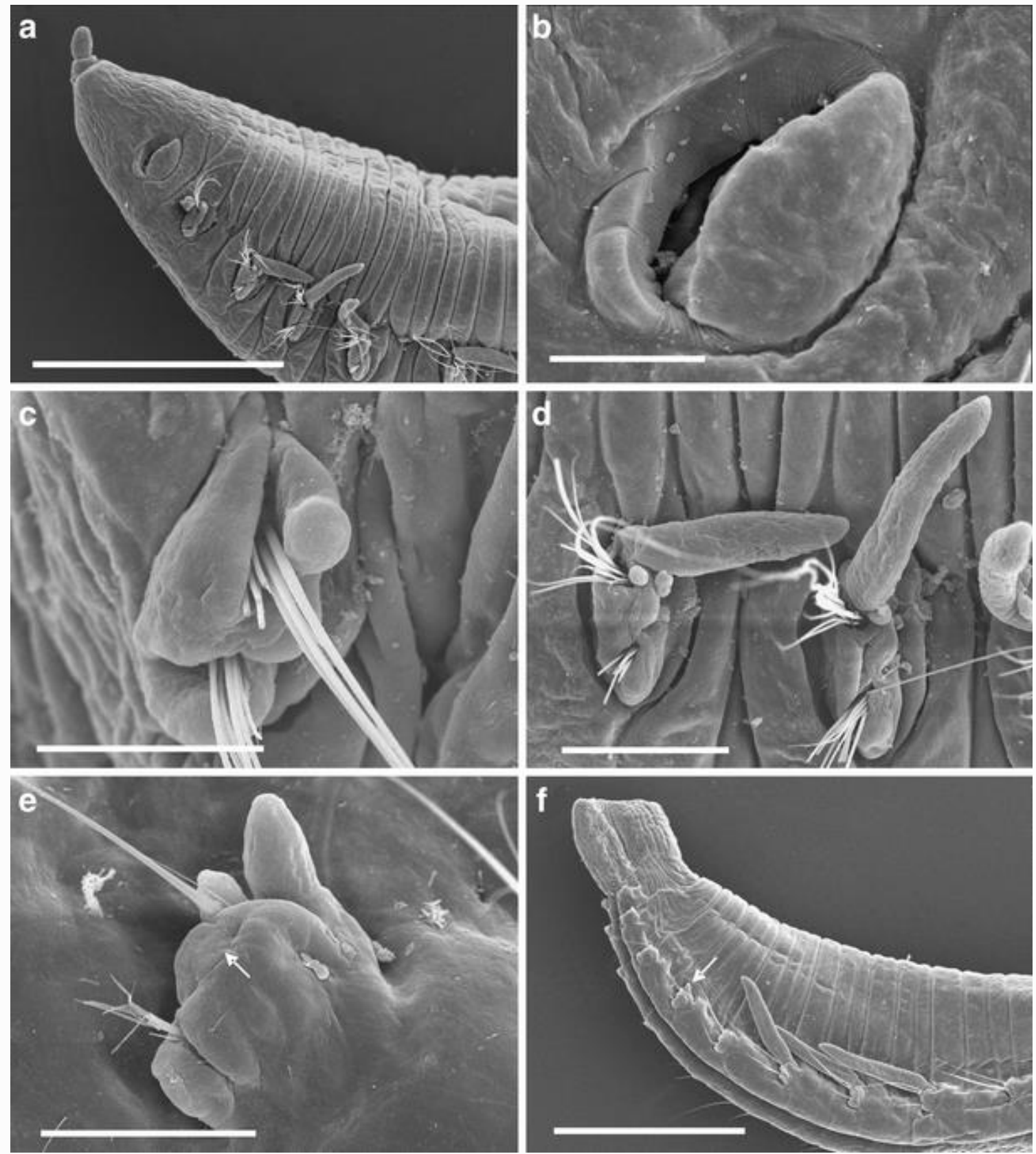

Fig. 11 Ophelina helgolandica Augener (IMNH 24329, BIOICE sample 2579). a Anterior end, lateral view. b Detail of nuchal organ. c First chaetiger. d Chaetigers 2-3. e Last branchiate chaetiger; arrow marks position of lateral organ. $\mathbf{f}$ Posterior body region, lateral view; arrow marks position of last branchiate chaetiger followed by three abranchiate chaetigers. Scale bars: (a,f) $1 \mathrm{~mm}$; (b, c, e), $100 \mu \mathrm{m} ;(\mathbf{d}) 200 \mu \mathrm{m}$ 


\section{Remarks}

The spelling of the epithet in the species name has been altered over time. The original spelling by Augener (1912), Ophelina helgolandiae, was followed in subsequent relevant works (e.g. StøpBowitz 1945, 1948), but recent authors have used the spelling $O$. helgolandica instead (e.g. Hansson 1998; Rowe 2010). For the present study, we have decided not to look into the reasons for this change, but to continue the spelling in recent usage to avoid confusion.

Augener (1912) provided a detailed description of $O$. helgolandica, including accurate drawings of both the anterior and posterior regions (Fig. 9e) and parapodia. According to Støp-Bowitz (1945), this species is mostly characterized by the shape of the palpode and the anal tube, as well as by the shape and distribution of branchiae. Støp-Bowitz (1945) considered synonymy of $O$. helgolandica with Ammotrypanella arctica and Ophelina opisthobranchiata Wirén, 1901. He pointed out significant morphological differences between $O$. helgolandica and $A$. arcticawhich were less apparent between $O$. helgolandica and $O$. opisthobranchiata due to the incomplete description of the latter. Støp-Bowitz (1945) proceeded to propose $O$. helgolandicaas a synonym of $O$. opisthobranchiata, as both species had been described from the same area, the deep sea off Spitsbergen. We have not been able to examine material under these two species names, but consider sympatric occurrence by itself as insufficient to justify synonymy. Støp-Bowitz (1948) extended the above synonymy to $O$. cylindricaudata (which was followed by Hartman 1959), but we do not share this point of view because of obvious differences in the shapes of the body, gills and anal tube (compare $O$. helgolandica in the present Fig. 9 with $O$. cylindricaudata in Parapar and Moreira 2008: figs. 4 and $6 e)$.

Augener (1912) called $O$. helgolandica close to $O$. delapidans (Kinberg). We follow the opinion of Støp-Bowitz (1945) in considering $O$. delapidans as a distinct species because of its distant type locality (Valparaiso, Chile) and the morphological differences in light of the accurate drawings by Ehlers (1901). Two other species, Ophelina norvegica Støp-Bowitz, 1945 (Figs. 9f and 10b) and $O$. groenlandica Støp-Bowitz, 1948 (Figs. 9d and 10a), might have been mistaken for $O$. helgolandica because of their similar body appearance. The descriptions and illustrations by StøpBowitz $(1945,1948)$, however, clearly point out that both are valid taxa; this conclusion is strengthened by our examination of museum specimens (holotype in the case of $O$. groenlandica). Eliason (1951) mentioned certain similarities between $O$. helgolandica and $O$. nybelini but unfortunately did not provide any details.

\section{Ophelina bowitzisp. nov.}

(Figs. 1d, 12, 13 and 14)

?Ammotrypanella arctica McIntosh—as misidentified by Fauvel (1914: 246); Kirkegaard (1996: 68).

\section{Etymology}

The species is named in honour of the Norwegian polychaetologist Dr. Carl Støp-Bowitz (19131997), Associate Professor at the University of Oslo, for his relevant contributions to the knowledge of the Norwegian and Arctic polychaetes, particularly of the Opheliidae. 
BIOICE material: 162 specimens $(1.36 \%$ of Opheliidae) in nine samples (see Electronic Supplementary Material), as follows. Holotype (Icelandic Museum of Natural History, IMNH 24320), BIOICE sample 3167: North Atlantic Ocean S of Iceland, bottom tow from $60^{\circ} 54^{\prime} 88^{\prime \prime} \mathrm{N}$ $22^{\circ} 47^{\prime} 26^{\prime \prime} \mathrm{W}$ to $60^{\circ} 55^{\prime} 28^{\prime \prime} \mathrm{N} 22^{\circ} 47^{\prime} 62^{\prime \prime} \mathrm{W}, 1897$ to $1899 \mathrm{~m}$ depth, 26 July 2000 , bottom temperature $2.98^{\circ} \mathrm{C} .10$ paratypes (BIOICE sample 3167, IMNH 24321); 14 paratypes (IMNH 24322, BIOICE 2860), 13 paratypes (IMNH 24323-24, 2863), 12 paratypes (IMNH 24325, BIOICE 2863DK); 1 paratype (MNCN 16.01/13272, BIOICE sample 3012DK), 1 paratype (MNCN 16.01/13273, BIOICE 3076). Complementary material (Icelandic Museum of Natural History): 8 specimens (BIOICE sample 2859), 72 spec. (2863), 2 spec. (3012), 3 spec. (3171DK), 8 spec. (3173), 17 spec. (3176-0.5).

\section{Diagnosis}

A large species mostly distinguishable by (1) the presence of branchiae that are very short in the anterior half of the body, larger in the posterior half, and short again in some chaetigers anterior to the last abranchiferous segments; (2) a large anal tube characteristically bent upwards and usually present in the specimens, wide in the basal part and becoming narrower in the distal part.

\section{Description (of holotype, unless otherwise mentioned)}

Body $39 \mathrm{~mm}$ long (15-43 $\mathrm{mm}$ in paratypes) and $2.5 \mathrm{~mm}$ wide (1.0-3.0 $\mathrm{mm}$ in paratypes); fusiform, with 45 chaetigers (44-46 in paratypes), deeply grooved both laterally and ventrally. Prostomium short and conical (Figs. 12a and 13a), with short palpode and two prominent nuchal organs (Fig. 13b). Eyes not observed. Parapodia rounded, provided with dorsal branchiae from second chaetiger, with a ventral tongue-shaped lobe (Fig. 13c-f) and a button-shaped ciliary organ (lateral

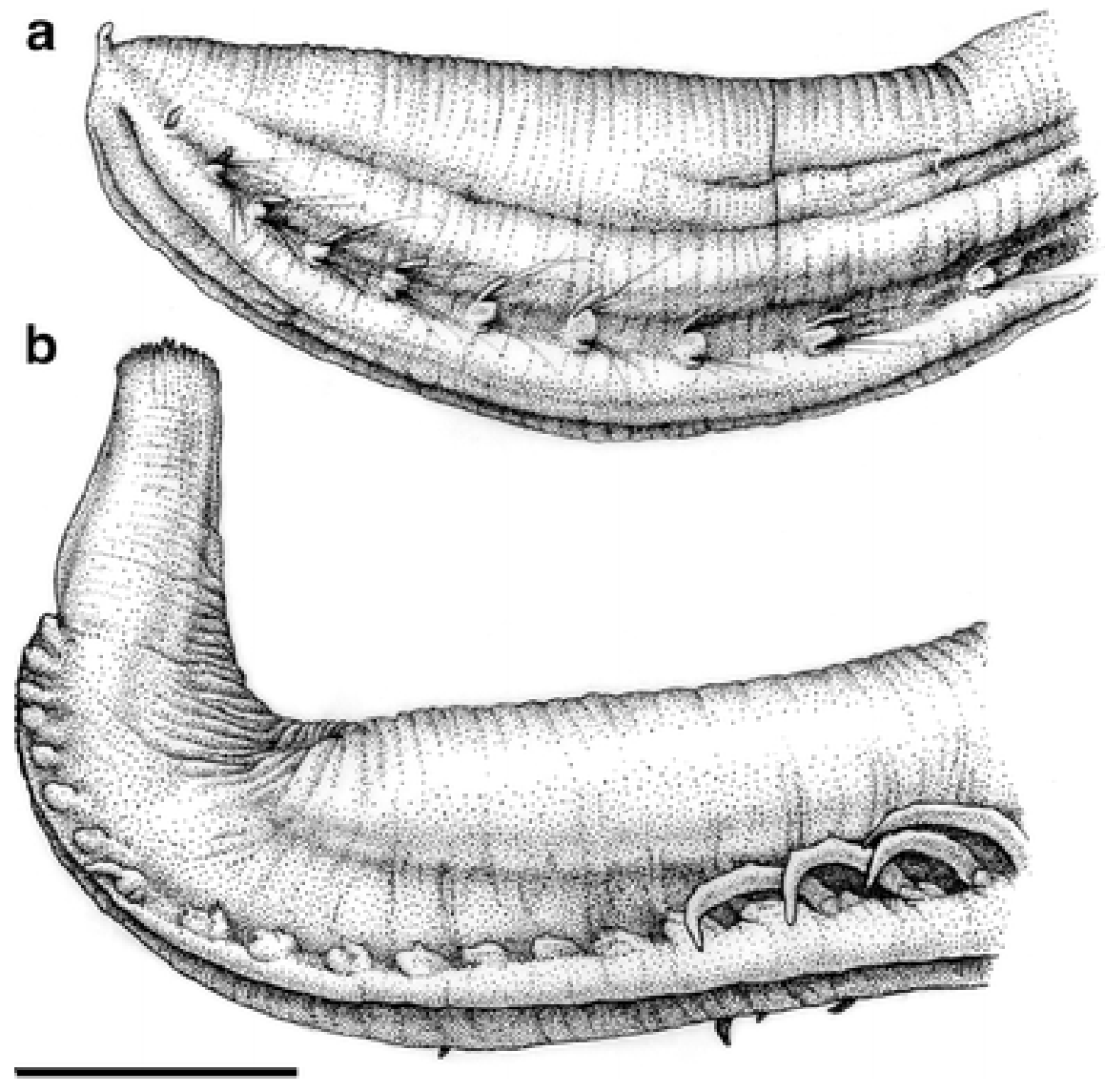

Fig. 12 Ophelina bowitzi sp. nov. (holotype, IMNH 24320).

a Anterior end, lateral view. bPosterior end, lateral view. Scale bar: $2 \mathrm{~mm}$ 
organ) between chaetal bundles (Fig. 13f). Branchiae short in first half of body (Figs. 12a and 13a, c, d), becoming much larger in middle body region (Fig. 14a, b), diminishing again in last quarter of body and disappearing in last chaetigers (Fig. 14c, d). Branchiae provided with two ciliary rows (Fig. 13e); surfaces of some long gills with small, blister-shaped bumps (Fig. 14b). Chaetae all smooth capillaries. Anal tube as long as last 10 chaetigers (Fig. 14e), becoming narrower from base to distal part, characteristically bent upwards and provided with about 10 short terminal cirri (Fig. 14f).
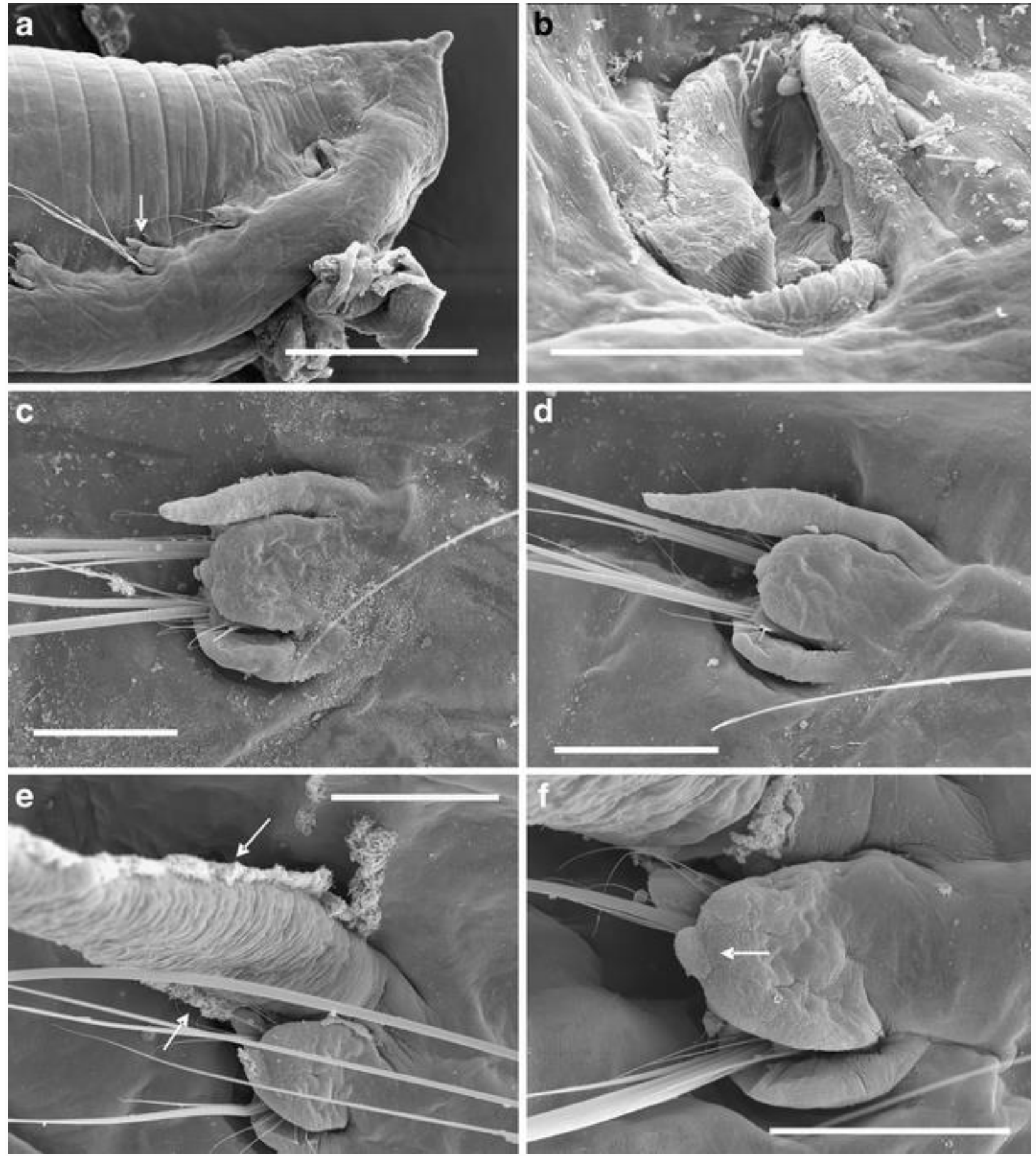

Fig. 13 Ophelina bowitzi sp. nov. (IMNH 24324, BIOICE sample 2863). a Anterior end, lateral view. b Detail of nuchal organ. $\mathbf{c}$ Chaetiger 11. d Chaetiger 18. e Chaetiger 25; arrows mark positions of two ciliary bands. (f) Chaetiger 28; arrow marks position of lateral organ. Scale bars: (a) $1 \mathrm{~mm}$; (b) $90 \mu \mathrm{m}$; (c, d, f) $100 \mu \mathrm{m}$; (e) $900 \mu \mathrm{m}$ 


\section{Occurrence}

Species restricted to deep $(1897-2709 \mathrm{~m})$ and temperate $\left(2.07-3.29^{\circ} \mathrm{C}\right)$ waters off the south coast of Iceland (Fig. 1d).

\section{Remarks}

Ophelina bowitzisp. nov. presents all the characters currently accepted as diagnostic for the genus Ophelina. However, its long body and the size of its branchiae make it very different from
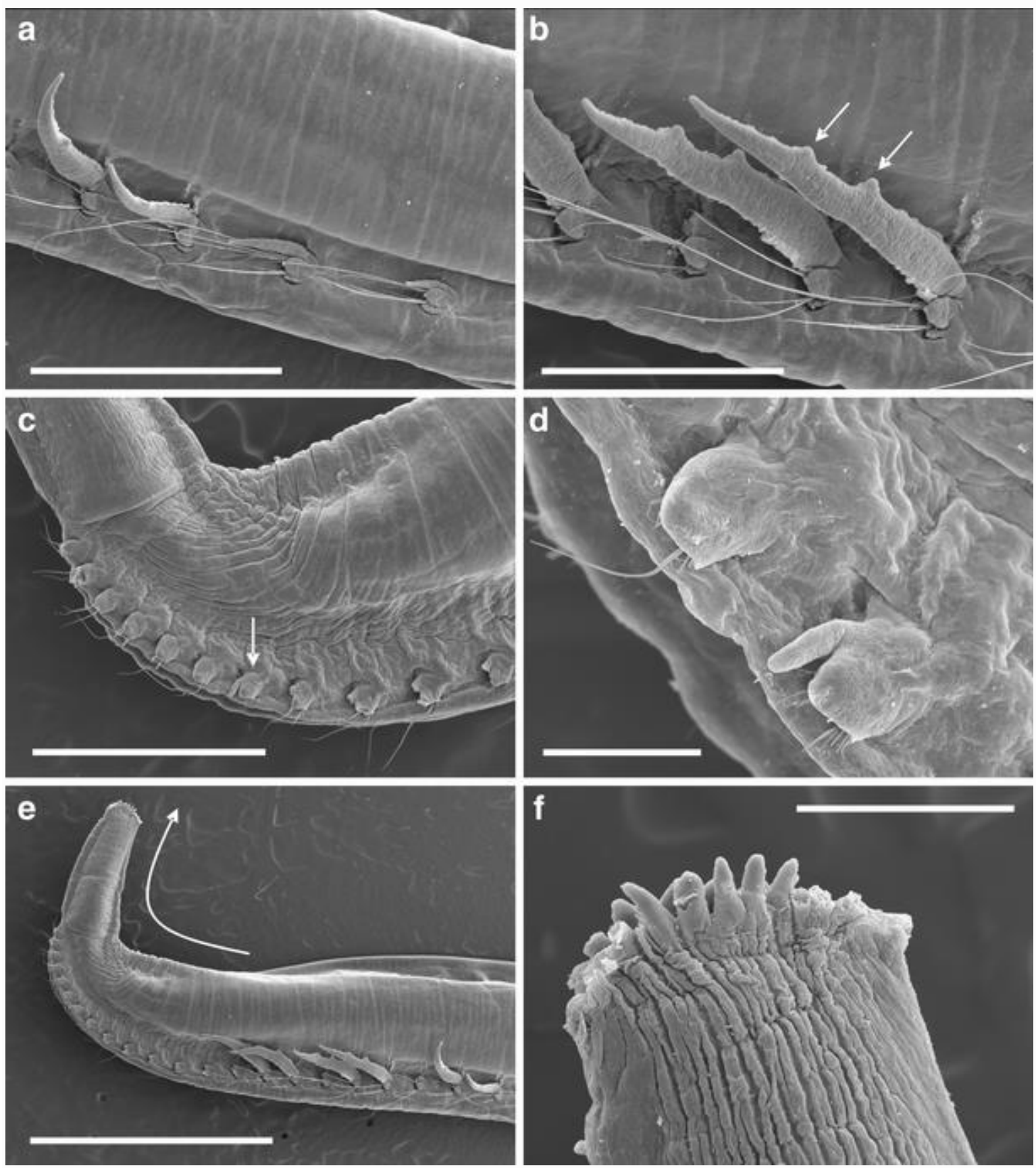

Fig. 14 Ophelina bowitzi sp. nov. (IMNH 24324, BIOICE sample 2863). a Mid-body chaetigers (branchiae lost on two chaetigers at right). b Chaetigers 27-30. $\mathbf{c}$ Last chaetigers, lateral view; arrow marks last branchiferous chaetiger. d Last branchiferous chaetigers. ePosterior end, lateral view; shape of arrow reflects typical bend to dorsal of posterior body region. f Detail of posterior end of anal tube. Scale bars: (a) $900 \mu \mathrm{m}$; (b) $500 \mu \mathrm{m}$; (c) $2 \mathrm{~mm}$; (d) $100 \mu \mathrm{m}$; (e) $700 \mu \mathrm{m}$; (f) $200 \mu \mathrm{m}$ 
congeneric species in the NEAW which are usually small and often have branchiae of the same size throughout the body (although they may be missing from the mid-body). Ophelina bowitzialso shows a considerable increase in branchiae length in the posterior region of the body. We agree with Schüller (2008) that the material from the Azores islands identified asAmmotrypanella arctica by Fauvel (1914) is unlikely to correspond to the latter species. That material was not examined by us, but according to the description and illustrations by Fauvel (1914), especially regarding the patterns of distribution and shape of the branchiae and anal tube (Fig. 9b), it is likely to belong to $O$. bowitzi sp. nov. The record by Kirkegaard (1996) of A. arctica from the Kermadec Trench (New Zealand) should also be reviewed because of the distance from the type locality of that species. Ophelina ammotrypanella Schüller, 2008, from Antarctic waters, corresponds fairly well to the description of $O$. bowitzi sp. nov. regarding the shapes and sizes of the body and anal tube and the absence of an anal cirrus. However, the two species differ in the shape of the nuchal organ (prominent in $O$. bowitzi sp. nov., indistinct in $O$. ammotrypanella), the upward bend of the anal tube in $O$. bowitzi, and especially in the presence in $O$. bowitzi of very small branchiae on some chaetigers preceding the abranchiate chaetigers near the end of the body.

SEM examination of Ophelina bowitzi sp. nov. has revealed, as in $O$. basicirra sp. nov., the presence of two ciliated bands associated to the branchiae and a well defined ciliated button between the dorsal and ventral chaetal bundles. In addition, small bumps have been observed on the surface of some gills. Similar structures were previously reported from Euzonus zeidleriHartmann-Schröder \& Parker, 1995 and described as small pinnae (Hartmann-Schröder and Parker 1995). However, based on our observations the latter structures might represent blister-shaped artefacts resulting from the fixation of specimens rather than a true branchial feature.

\section{Genus Tachytrypane McIntosh,1878}

\section{Tachytrypane jeffreysii McIntosh,1878}

Tachytrypane jeffreysii McIntosh-McIntosh (1878: 505); Fauvel (1927: 135); Støp-Bowitz (1948: 24); Eliason (1951: 135); Hartman and Fauchald (1971: 134); Castelli et al. (1995: 11); Martínez and Adarraga (2001: 42).

\section{Material examined}

BIOICE material: 21 specimens (0.18\% of Opheliidae) in ten samples (see Electronic Supplementary Material).

\section{Occurrence}

Species restricted to relatively warm waters $\left(2.07-4.78^{\circ} \mathrm{C}\right)$ of the southeast to southwest coast of Iceland, always below the $1000 \mathrm{~m}$ isobath $(1066-2709 \mathrm{~m})$.

\section{Previously reported distribution}

The few known records indicate that $T$. jeffreysii is mostly restricted to the North Atlantic Ocean. This species was originally described from the Davis Strait between Canada and Greenland, then recorded from European coasts by Fauvel (1927), Støp-Bowitz (1948) and Martínez and Adarraga (2001), from the Central North Atlantic by McIntosh (1878) and Eliason (1951), from the 
Mediterranean Sea (Adriatic) by Castelli et al. (1995), and from North America by Hartman and Fauchald (1971).

\section{Key to the species of the genus Ophelina in the NE Atlantic}

The main taxonomic characters used to discriminate species in the genus Ophelina include presence/absence and arrangement of branchiae, and the shapes of the anal tube and anal cirrus. The examination of a large number of specimens collected during the BIOICE expeditions suggests, however, that characters concerning the anal tube and anal cirrus should be used with caution when discriminating species. These structures are highly deciduous in many species (e.g. $O$. abranchiata, $O$. cylindricaudata and $O$. basicirra sp. nov.); therefore, their absence in a particular specimen does not mean that they are actually absent in the species.

The key provided here contains the European species of Ophelina traditionally considered as valid (Bellan 2001; Hansson 1998), including those which we have examined directly from BIOICE material or specimens deposited in museums, and those for which only the original descriptions have been checked. A complete revision of all European species based on direct examination of (ideally name-bearing type) specimens remains desirable and the prerequisite to learning the true diversity in the genus.

1. Branchiae absent. O. abranchiata

- Branchiae present .2

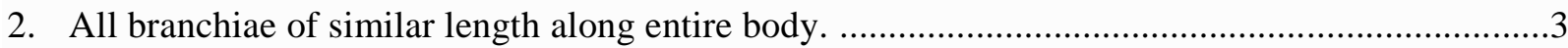

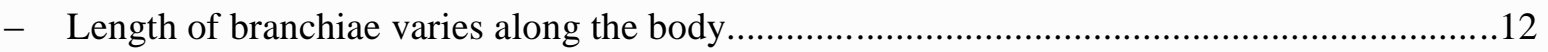

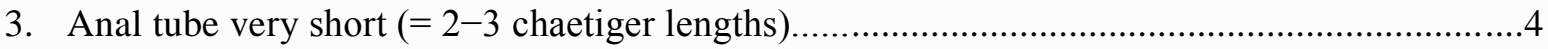

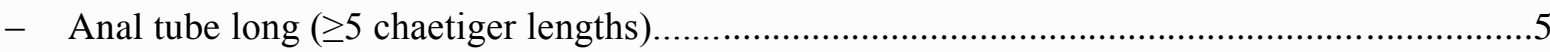

4. Anal tube terminating in 6-8 minute papillae.......................................................... modesta

- Anal tube terminating in 6 large, subequal papillae.................................................... margaleffi

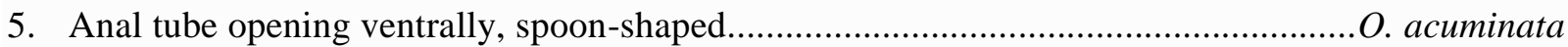

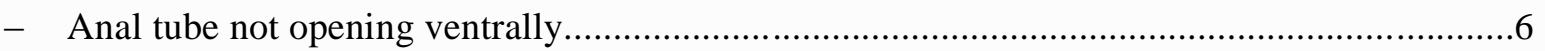

6. Posterior chaetigers provided with branchiae; anal tube with proximal anal

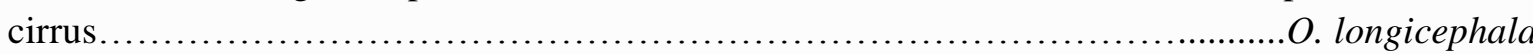

- Posterior chaetigers abranchiate; anal tube with or without proximal anal cirrus ................ 7

7. Anal tube longer than posterior abranchiate region; without distal cirri....................................

- Anal tube of similar length as, or shorter than, posterior abranchiate region................................10

8. Anal tube funnel-shaped with opening broader than base.......................................... norvegica

- Anal tube with opening of same diameter as base ...............................................................

9. Anal tube without cirri; last four chaetigers crowded and pushed toward mid-ventral body

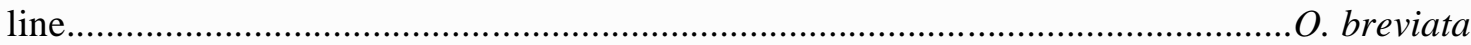

- Anal tube provided with short distal cirri and ventral proximal anal cirrus; last four chaetigers not as above.

O. basicirra sp. nov.

10. Anal tube distally undulated, with one short anal cirrus at base O. nybelini

- Anal tube with distal cirri, with or without anal cirrus at base................................................11

11. Anal tube almost as high as long, dorsally truncated, with short distal cirri easily detachable. O. helgolandica

- Anal tube longer than high, not dorsally truncated, with one anal cirrus O. groenlandica

12. Branchiae, if present, shorter in middle third of the body; anal tube provided with short distal anal cirrus; last abranchiate chaetigers crowded and pushed toward mid-ventral body line. O. cylindricaudata 
- Branchiae short in anterior half of body; anal tube without anal cirrus; last abranchiate chaetigers not as above.

O. bowitzi sp. nov.

Ophelina breviata (Ehlers, 1913) is the only species in the genus with a type locality outside of European waters. Its distribution is mostly Antarctic with records scattered all over Austral seas (Augener 1932; Hartman 1966; Monro 1930). There are also records from Alaska (Pettibone1954), Madagascar, New Zealand and South Australia (Glasby and Read 1998; Kirkegaard1996), and Argentina (Elías and Bremec 2003). In European waters, Aguirrezabalaga et al. (1992) and Parapar and Moreira $(2008,2009)$ reported $O$. breviata from the Iberian Peninsula. Pettibone (1954) suggested possible synonymisation with Ophelina groenlandica despite the apparent difference in body size. We do not follow her opinion, however, as there are observed differences in the shape of the anal tube (compare $O$. groenlandica in the present Fig. 9d to Antarctic O. breviata in Parapar and Moreira 2008: fig. 3G).

Six other species included in the key have not been recorded in Icelandic waters: $O$. norvegicaStøpBowitz, 1945 (type $\quad$ locality: $\quad$ Norway), O. modesta Støp-Bowitz, 1948 (Norway), O. groenlandica Støp-Bowitz, 1948 (East $\quad$ Greenland), $O . \quad$ nybelini Eliason, 1951 (Azores), $O$. longicephala Hartmann-Schröder, 1977 (off South Portugal), and O. margaleffi Sardá et al.,2009 (NE Spain). These species are considered as valid here after review of the original descriptions and drawings and the study of museum specimens. Among them, only $O$. modestahas been reported from outside its type locality; Parapar and Moreira (2008) recorded it off Galicia (NW coast of Iberian Peninsula).

Other species or subspecies originally described within the genus Ammotrypane from European or nearby areas but not included in the key are: Ophelina ingebrigtsenii (Kükenthal, 1887), $O$. opisthobranchiata Wirén, 1901, O. $\quad$ kukenthali (McIntosh, 1908), O. $\quad$ sarsi (Eliason, 1962), O. chaetifera (Hartman, 1965), O. aulogastrella (Hartman \& Fauchald, 1971), and O. cilindricaudata minima Hartmann-Schröder (1974). In addition there are two unidentified species reported by Hartmann-Schröder (1974). All of these have been mentioned scarcely in the literature.

Ophelina ingebrigtsenii (Kükenthal), from Spitsbergen, is now regarded as junior synonym of $O$. acuminata Örsted 1843 (Hartman 1959).

Ophelina opisthobranchiata Wirén, also from Spitsbergen (Wirén 1901), was considered by Hartman (1959) as a probable junior synonym of Ammotrypanella arctica or O. cylindricaudata. Hansson (1998) regarded it as a possible synonym of $O$. helgolandica; on the contrary, Bellan (2001) recognized $O$. opisthobranchiata as valid (with the name incorrectly spelled $O$. opisthobranchia).

The description by McIntosh (1908) of Ammotrypane (Ophelina) kukenthali from the North Atlantic mentions a slender, smooth, glistening body (“... like that of Polygordius ...”). This feature, along with the absence of bristles as well as of cirri and papillae on the caudal process, suggests that the species involved might actually be Tachytrypane jeffreisii, which had been described several years before by McIntosh (1878) as well.

Ophelina sarsi (Eliason), originally described from the Skagerrak, is now regarded as a junior synonym of $O$. modesta Støp-Bowitz (Hansson 1987). 
Ophelina chaetifera (Hartman) and $O$. aulogastrella (Hartman \& Fauchald) were reported from the Atlantic Ocean at latitudes close to each other. Ophelina chaetifera from off New England (northwest Atlantic) and off northeast South America is a small species (up to $12.2 \mathrm{~mm}$ in length) considered by Hartman (1965) and Hartman and Fauchald (1971) as allied to O. cylindricaudata. However, the two differ in body length, number of total body chaetigers, and number of anterior and posterior chaetigers provided with branchiae.

Ophelina aulogastrella (Hartman \& Fauchald), described from tropical latitudes in the Atlantic Ocean, resembles $O$. acuminata in the shape of the anal tube, but lacks branchiae in the posterior half of the body, and the last chaetiger is followed by six to nine annuli without parapodia (see Hartman and Fauchald 1971: plate 21).

Hartmann-Schröder (1974) mentioned three supposedly new Ophelina from Norway: $O$. cilindricaudata minima, Ophelina sp1, and Ophelina sp2. Ophelina cylindricaudata minimadiffers from $O$. cylindricaudata s. str. in its small size and fewer segments (Hartmann-Schröder1974). Later, Hartmann-Schröder (1996) elevated it to species rank, but without providing further explanations or presenting any illustration. Because of that, we consider all these three taxa proposed in HartmannSchröder (1974) as insufficiently characterized and exclude them from the key.

\section{Discussion}

Eight opheliid genus names are currently recognized as valid; another 15 have been synonymised along the taxonomic history of the family. Fauchald (1977) counted 11 genera, namely Ammotrypanella McIntosh, 1878, Antiobactrum Chamberlin, 1861, Dindymenides Chamberlin, $\quad$ 1919, Euzonus Grube, 1919, Armandia Filippi, 1919, OpheliaSavigny, 1822, Ophelina Örsted 1843, Polyophthalmus de Quatrefages, 1850, TachytrypaneMcIntosh, 1878, and Travisia Johnston, 1840. Since then, Lobochesis was added by Hutchings and Murray (1984) but subsequently synonymised with Euzonus by Santos et al. (2004).Dindymenides and Kesun have been synonymised with Travisia by Dauvin and Bellan (1994), and Travisia has been placed in the family Scalibregmatidae Malmgren, 1867 by Bleidorn et al. (2003); note, however, that Maciolek and Blake (2006) and Sene-Silva (2007) did not support this genus transfer. In the NE Atlantic, where cold waters of Nordic Seas and warm waters from the northeast Atlantic Ocean converge, seven genera of Opheliidae have been reported (Bellan2001; Hansson 1998); Antiobactrum has not been found.

The examinations of the opheliid material from the BIOICE expeditions has revealed the presence of four genera: Ammotrypanella, Ophelia, Ophelina, and Tachytrypane. No species ofArmandia, Euzonus or Polyophthalmus have been found. Euzonus is represented in European waters by E. flabelligerus (Ziegelmeier, 1955), Armandia by A. cirrhosa Filippi, 1861 and A. polyophthalma Kükenthal, 1887, and Polyophthalmus by P. pictus (Dujardin, 1839).

The genera Ophelia and Tachytrypane are represented in NEAW by eleven and one species, respectively. In the present study, Ophelia is recorded on account of a few specimens of $O$. limacina collected from shallow bottoms of the northwest coast; its scarce presence in the BIOICE material is possibly due to the lack of sampling in the intertidal zone and to only few samples taken in shallow waters $(<50 \mathrm{~m})$ where this genus is usually found (Bellan and Dauvin1991). The only recorded member of Tachytrypane, $T$. jeffreysii, was found on the south Icelandic deep slope, corresponding to the habitat from which this species is usually reported. 
Ammotrypanella has traditionally been treated as monotypic. Schüller (2008) redescribed the type species and proposed three new species from the study of Antarctic material based on the presence or absence of an anal tube and anal cirrus. We consider observed 'absence' in this character as too unreliable for diagnostic and nomenclatural purposes, as those body parts are easily detached during sampling or handling of the specimens.

The genus Ophelina is the most speciose in NEAW, with 16 species reported so far; Ophelinaspecies are also the dominant opheliids in studies conducted at shelf and slope depths (e.g. Maciolek and Blake 2006; $\quad$ Schüller 2008). $\quad$ Thus, $O$. abranchiata and $O$. cylindricaudata, along with A. cf. arctica (which shows many morphological and ecological similarities with the genusOphelina), were the numerically dominant taxa, comprising nearly $90 \%$ of the BIOICE opheliid material.

Some Opheliidae, such as Ophelia and Armandia, are well known taxonomically and ecologically because they are common in intertidal and shallow waters and, therefore, more accessible for sampling. In contrast, Ophelina species are mainly present on deeper bottoms of the continental shelf and slope where they can become one of the most relevant faunal components (Cúrdia et al. 2004; Maurer and Williams 2007; Schüller and Ebbe 2007). The knowledge of the actual diversity and ecology in this genus has improved in the last decades (Elías et al. 2003; Hartmann-Schröder and Parker 1995; Maciolek and Blake 2006; Schüller2008), mostly due to the study of material collected in several research projects devoted to the knowledge of the deep-sea fauna (e.g. USARP, ANDEEP and BENTART in Antarctica, BIOICE in Iceland, DIVA in the Atlantic, and DIVA-Artabria in the NW Iberian Peninsula).

Species of Ophelia and Armandia can be distinguished by means of well defined, non-subjective characters such as the number of abranchiate anterior and posterior chaetigers and the number of segments bearing branchiae. By contrast, in Ophelina the scope of reliable characters for taxonomic characterization has yet to be established. Traditionally, the presence/absence and shape of the anal tube has been used as the most important diagnostic feature by far. As stated above, however, any species identification based on nothing but the absence of an external morphological structure, e.g. of the anal tube or anal cirrus, can be risky if that structure is deciduous by nature. Such traits can be lost from specimens that are handled roughly during the collection and preservation processes (Blake 2000). Because of this, it would be appropriate to examine as many animals as feasible in such cases, in order to assess presence/absence as reliably as possible.

The formation of the GIF Ridge in the time interval 57-16 million years ago involved deep changes in the ocean circulation in the North Atlantic. In this area, water masses with different geographical origins and physicochemical characteristics converge, which results in a complex hydrography (Hansen and Østerhus 2000; Malmberg and Valdimarsson 2003). Therefore it is possible that this geological event has played a role in the evolution of the species and geographical distribution of the populations over the last million years.

The study of BIOICE material has revealed considerable differences in the geographical and bathymetric ranges of the opheliid species. Three distribution patterns were observed: (1) species from shallow waters near the coastline, (2) species of the continental shelf and slope limited to the south of the GIF Ridge, and (3) species of the continental shelf and slope along the entire coast of Iceland. The first pattern is represented by Ophelia limacina, the second by $T$. jeffreisii and the two new species described above. All remaining species display the third pattern. The latter, in turn, can be subdivided into three subpatterns depending on the depth: (3a) species mainly found on the 
continental shelf and upper slope (above the $600 \mathrm{~m}$ isobath; $O$. acuminata), (3b) species of the deep slope (below the $600 \mathrm{~m}$ isobath; A. cf. arctica and $O$. helgolandica), and (3c) species with wide depth ranges (O. abranchiata; O. cylindricaudata). The presence of new species south of the GIF Ridge has been reported already for other polychaetes found in the framework of the BIOICE expeditions (Kirkegaard 2001; Parapar2003; Sigvaldadóttir 2002). The two species added here are also restricted to southern warm waters, and in the case of $O$. bowitzi sp. nov. also to bathyal environments (below $1000 \mathrm{~m}$ ), as was the case with $T$. jeffreisii. Such pronounced limits in species distribution in relation to the GIF Ridge have been reported also for other groups of marine invertebrates such as hydrozoans (Schuchert 2000), molluscs (Dijkstra et al. 2009), amphipods (Weisshappel 2000, 2001), and isopods (Brix and Svavarsson 2010).

Although little is known about the life cycles of the species of Ophelina, we can infer a probable planktonic larval stage in their reproductive cycle from information available on other opheliid genera, mostly Ophelia and Armandia (Rouse 2001). This would make these species highly efficient in dispersal, with a great capacity to surmount the topographical barrier imposed by the GIF Ridge. Therefore, it is likely that the distribution of the opheliids is more determined by ecological conditions of the environment (e.g. temperature) than by the ridge itself, as has been demonstrated for isopods by Brix and Savavarsson (2010). The presence of $O$. basicirra sp. nov. south of the GIF Ridge, but at depths shallower than the GIF average sill $(620 \mathrm{~m}$ in the Denmark Strait, $420 \mathrm{~m}$ between Iceland and the Faeroe Islands), seems to support that hypothesis. The species is not found north of the ridge, probably due to unsuitable cold temperatures; the opposite pattern (3c) occurs in $O$. abranchiata and $O$. cylindricaudata, which are apparently able to deal with a wider range of temperatures. Something similar might be the case with $A$. cf. arctica and $O$. helgolandica (pattern $3 \mathrm{~b}$ ), the bathymetric ranges of which are, however, lower than sill depths of the Ridge. On the other hand, the probability of the presence of cryptic species in these cases cannot be excluded.

Several species found in Icelandic waters (e.g. $O$. acuminata and $O$. cylindricaudata) have traditionally been considered as cosmopolitan. Schüller (2008) regarded A. arctica as having a bipolar ("if not cosmopolitan") distribution, and Kirkegaard (1996) expressed a similar point of view for $O$. breviata. Broecker and Denton (1989) attempted to explain this distribution with a deep saline current which originates in the Arctic-Atlantic region and travels all the way to the Antarctic, beginning at deeper levels and then rising to shallower ones. Nevertheless these patterns should be reassessed in the future, taking into account detailed morphological examinations as well as molecular data from populations all across the species' known distribution ranges, in order to exclude the possibility of complexes of closely related species.

The use of SEM in the present work has revealed some characters that may be useful to future phylogenetic studies of the family. These are the shape of nuchal organs, the shape and location of lateral organs on the body, and the ciliature associated with segments and branchiae. Our study has revealed previously unreported differences between species in the shape of the opening of the nuchal organ. The horizontally oval shape in $O$. abranchiata and the button-hole shape in A. cf. arctica are very different from those in the other opheliid species studied (O. basicirra sp. nov., O. helgolandica, and $O$. bowitzi sp. nov.), in which the presence of a large posterior lappet is evident. The presence of lateral organs between the two parapodial chaetal bundles seems constant in the Opheliidae (Hartmann-Schröder 1958; Purschke 2005). The fact that this structure appears anterior to the first bundle of chaetae in $O$. abranchiata seems to indicate the presence of three achaetous segments posterior to the peristome. Finally, the locations and distribution of body cilia and chaetae ornamentation are two aspects poorly studied so far. Both were described by Sardá et al. (2009) for $O$. margaleffi, where they are very similar to those found in $O$. basicirra sp. nov. Future studies 
will reveal whether this reflects exclusive phylogenetic affinity or, rather, a feature also shared by other species of the genus.

\section{Acknowledgements}

This work was partially supported by the research projects Fauna Ibérica VIII: Annelida Polychaeta III (CGL2004-04680-C10-02) and Fauna Iberica IX: Annelida Polychaeta IV(CGL2007-66786-C0802), Gobierno de España (Spain). Several grants from the European Union's TMR (Training and Mobility of Researchers) program and the UDC financed several visit of senior author (JP) to the SMC. JP also gratefully acknowledges Synthesis support made available by the European Community-Research Infrastructure Action under the FP6Structuring the European Research Area (Projects DK-TAF-3118 and SE-TAF-4599) to visit the Zoologisk Museum, University of Copenhagen, and the Swedish Museum of Natural History (Stockholm). D. Eibye-Jacobsen and M.T. Tøttrup (ZMUC) and E. Sigvaldadottir and K. Sindemark (SMNH) are greatly acknowledged for their help during JP stay in both institutions. Special thanks to S. Bragadottir and the rest of the women of the SMC involved in sorting the specimens from the BIOICE samples. The authors wish to thank J. Gil (CSIC Blanes, Spain) by making available to us relevant bibliography, C.A. Högström (Göteborgs Naturhistoriska Museum, Sweden) for sending photographs of the type material of $O$. nybelini, A. Castro and C. Sueiro (SAIN, UDC) who assisted with the preparation of specimens and use of the SEM, D. Romero (UDC) for the line drawings, N. Sánchez (UDC) and G. Gudmundsson (IMNH) for the maps and J. García-Carracedo for reviewing the English version of the manuscript. Thanks are also due to M. Schüller, D. Eibye-Jacobsen and ODE editors for their helpful comments on an early version of the manuscript.

\section{References}

Aguirrezabalaga, F., Ibáñez, M., \& Ros, J. (1992). Taxocenosis anelidianas en el piso circalitoral de la costa vasca. Actas del V Simposio Ibérico de Estudios del Bentos Marino, 2, 149-159.

Augener, H. (1912). Beitrag zur Kenntnis verschiedener Anneliden und Bemerkungen über die nordischen Nephthys-Arten und deren epitoke Formen. Archiv für Naturgeschichte, 78, 162-212.

Augener, H. (1932). Antarktische und Antiboreale Polychaeten nebst einer Hirudinee. Scientific Results of the Norwegian Antarctic Expeditions, 1927-1928(9), 1-86.

Bellan, G. (1961). Contribution a l'etude de la Polychéte Ophelia bicornis Savigny 1820. Rapports et Procèsverbaux des Réunions de la Commission Internationale pour l'Exploration Scientifique de la Mer Méditerranée, 16, 533-550.

Bellan, G. (1964). Contribution a l'étude systématique, bionomique et écologique des Annélides Polychètes de la Méditerranée. Recueil des Travaux de la Station Marine d'Endoume, 49, 1-372.

Bellan, G. (1975). Ophelia rullieri n. sp., Opheliidae (Annélide Polychète sédentaire) des côtes gaspésiennes (Canada). Bulletin de la Société Zoologique de France, 100, 421-425.

Bellan, G. (2001). Polychaeta. Collection Patrimoines Naturels, 50, 214-231.

Bellan, G., Bellan-Santini, D., \& Dauvin, J. C. (1990). Phénétique et phylogénie des Opheliidae (Annélides Polychètes). Comptes Rendus de l'Academie des Sciences, Paris, 310, 175-181.

Bellan, G., \& Costa, H. (1987). Deux nouvelles espèces d'Ophelia abranches (Polychaeta, Opheliidae): $O$. laubieri et O. amoureuxi. Bulletin du Muséum National d'Histoire Naturelle Paris Sér, 4(9), 829-834.

Bellan, G., \& Dauvin, J. C. (1991). Phenetic and biogeographic relationships in Ophelia(Polychaeta, Opheliidae). Bulletin of Marine Science, 48, 544-558.

Bellan, G., \& Picard, J. (1965). Contributions a l'étude des Polychètes de la région Tuléar (République Malgache). I. Ophelia peresi n. sp. Bulletin de la Société Zoologique de France, 90, 295-298.

Bellan-Santini, D., Dauvin, J. C., \& Bellan, G. (1992). Approche phénétique et phylogénétique des Ophelia (Annelides Polychètes) de Méditerranée occidentale. Bulletin de l'Institut Océanographique, Monaco, 9, 67-81. 
Blake, J. (2000). Family Opheliidae Malmgren, 1867. In J. A. Blake, B. Hilbig, \& P. V. Scott (Eds.), Taxonomic atlas of the benthic fauna of the Santa Maria Basin and western Santa Barbara Channel, vol. 7 - The Annelida, Part 4. Polychaeta: Flabelligeridae to Sternaspidae(pp. 145-168). Santa Barbara: Santa Barbara Museum of Natural History.

Bleidorn, C., Vogt, L., \& Bartolomaeus, T. (2003). New insights into polychaete phylogeny (Annelida) inferred from 18S rDNA sequences. Molecular Phylogenetics and Evolution, 29, 279-288.

Borowski, C. (2001). Physically disturbed deep-sea macrofauna in the Peru Basin, southeast Pacific, revisited 7 years after the experimental impact. Deep-Sea Research II, 48, 3809-3839.

Borowski, C., \& Thiel, H. (1998). Deep-sea macrofaunal impacts of a large scale physical disturbance experiment in the south east Pacific. Deep-Sea Research II, 45, 55-81.

Brix, S., \& Svavarsson, J. (2010). Distribution and diversity of desmosomatid and nannoniscid isopods (Crustacea) on the Greenland-Iceland-Faeroe Ridge. Polar Biology, 33, 515-530.

Broecker, W. S., \& Denton, G. H. (1989). The role of ocean-atmosphere reorganizations in glacial cycles. Geochimica et Cosmochimica Acta, 53, 2465-2501.

Castelli, A., Abbiati, M., Badalamenti, F., Bianchi, C. N., Cantone, G., Gambi, M. C., et al. (1995). Annelida Polychaeta, Pogonophora, Echiura, Sipuncula. In A. Minelli, S. Ruffo, \& S. La Posta (Eds.), Checklist delle specie della fauna italiana (pp. 5-45). Bologna: Edizioni Calderini.

Chambers, S. J., \& Woodham, A. (2003). A new species of Chaetozone (Polychaeta: Cirratulidae) from deep water in the northeast Atlantic, with comments on the diversity of the genus in cold northern waters. Hydrobiologia, 496, 41-48.

Cúrdia, J., Carvalho, S., Ravara, A., Gage, J. D., Rodrigues, A. M., \& Quintino, V. (2004). Deep macrobenthic communities from Nazaré Submarine Canyon (NW Portugal). Scientia Marina, 68, 171-180.

Dauvin, J. C., \& Bellan, G. (1994). Systematics, ecology and biogeographical relationships in the sub-family Travisinae (Polychaeta, Opheliidae). Mémoires du Muséum d'Histoire Naturelle, 162, 169-184.

Day, J. H. (1961). The polychaete fauna of South Africa. Part 6. Sedentary species dredged off cape shores with a few new records from the shore. Journal of the Linnean Society of London, 44, 463-560.

Day, J. H. (1967). A monograph on the Polychaeta of southern Africa. Part 2. Sedentaria. London: Trustees of the British Museum (Natural History).

Day, J. H. (1973). New Polychaeta from Beaufort, with a key to all species recorded from North Carolina. NOAA Technical Report NMFS CIRC-375. Woods Hole, MA: National Marine Fisheries Service.

Dijkstra, H. H., Warén, A., \& Gudmundsson, G. (2009). Pectinoidea (Mollusca: Bivalvia) from Iceland. Marine Biology Research, 5, 207-243.

Ditlevsen, H. (1929). Polychaeta. Zoology of the Faeroes, 16, 1-83.

Ehlers, E. (1901). Die Polychaeten des magellanischen und chilenischen Strandes. In Festschrift zur Feier des hundertfünfzigjährigen Bestehens der königlichen Gesellschaft der Wissenschaften zu Göttingen. Abhandlungen der Mathematisch-physikalischen Klasse (pp. 1-232, pl. I-XXV). Berlin: Weidmannsche Buchhandlung.

Elías, R., \& Bremec, C. S. (2003). First record of the genus Armandia (Opheliidae, Polychaeta) in Argentine waters, with the description of Armandia loboi sp. n. Bulletin of Marine Science, 72, 181-186.

Elías, R., Bremec, C.-S., da Cunha Lana, P., \& Orensanz, J. M. (2003). Opheliidae (Polychaeta) from the southwestern Atlantic ocean, with the description of Travisia amadoi n. sp., Ophelina gaucha n. sp. and Ophelina alata n. sp. Hydrobiologia, 496, 75-85.

Eliason, A. (1951). Polychaeta. In H. Pettersson (Ed.), Reports of the Swedish deep-sea expedition 1947-1948. Vol. II. Zoology. Fascicle II (pp. 131-149). Göteborg: Kungliga Vetenskaps- och Vitterhets-Samhället i Göteborg.

Eliason, A. (1962). Die Polychaeten der Skagerrak-Expedition 1933. Zoologiska Bidrag från Uppsala, 33, 207293.

Fauchald, K. (1977). The polychaete worms. Definitions and keys to the orders, families and genera. Natural History Museum of Los Angeles County, Science Series, 28, 1-188.

Fauvel, P. (1914). Annélides Polychètes non pélagiques provenant des campagnes de l'Hirondelle et de la Princesse-Alice. In M. J. Richard (Ed.), Résultats des campagnes scientifiques accomplies sur son yacht par Albert ${ }^{\text {er }}$ Prince Souverain de Monaco (pp. 1-432). Monaco: Imprimerie de Monaco. 
Fauvel, P. (1925). Sur les Ophéliens des cotes de France. Bulletin de la Société Zoologique de France, 50, $77-$ 88.

Fauvel, P. (1927). Polychètes sédentaires. Addenda aux errantes, Archiannélides, Myzostomaires. Faune de. France, 16, 1-494.

Gardarsson, A. (1973). Some polychaetes new to the Icelandic fauna. Sérprentun úr Náttúrfraedingurinn, 43, 77-91 [In Icelandic with English summary].

Glasby, C. J., \& Read, G. B. (1998). A chronological review of polychaete taxonomy in New Zealand. Journal of Royal Society of New Zealand, 28, 347-374.

Hansen, B., \& Østerhus, S. (2000). North Atlantic-Nordic Seas exchanges. Progress in Oceanography, 45, 109-208.

Hansen, G. A. (1878). Annelider fra den norske Nordhavsexpedition I 1876. Nyt Magazin for Naturvidenskaberne, 24, 1-17.

Hansson, H. G. (1998). North East Atlantic Taxa / NEAT*Annelida. http://www.tmbl.gu.se/libdb/taxon/neat_pdf/NEAT*Annelida.pdf. Accessed 18 March 2011.

Hartman, O. (1938). Descriptions of new species and new generic records of polychaetous annelids from California of the families Glyceridae, Eunicidae, Stauronereidae and Opheliidae. University of California Publications in Zoology, 43, 93-111.

Hartman, O. (1959). Catalogue of the polychaetous annelids of the world. Occasional Papers of the Allan Hancock Foundation, 23, 1-628.

Hartman, O. (1965). Deep-water benthic polychaetous annelids off New England to Bermuda and other North Atlantic areas. Occasional Papers of the Allan Hancock Foundation, 28, 1-378.

Hartman, O. (1966). Polychaeta Myzostomidae and Sedentaria from Antarctica. Antarctic Research Series, 7, $1-158$.

Hartman, O. (1969). Atlas of the sedentariate polychaetous annelids from California. Los Angeles: Allan Hancock Foundation, University of Southern California.

Hartman, O., \& Fauchald, K. (1971). Deep-water benthic polychaetous annelids off New England to Bermuda and other North Atlantic areas, Part II. Allan Hancock Monographs in Marine Biology, 6, 1-327.

Hartmann-Schröder, G. (1958). Zur Morphologie der Opheliiden (Polychaeta, Sedentaria). Zeitschrift für Wissenschaftliche Zoologie, 161, 84-143.

Hartmann-Schröder, G. (1974). Polychaeten von Expeditionen der "Anton Dohrn" in Nordsee und Skagerrak. Veröffentlichungen des Instituts für Meeresforschung in Bremerhaven, 14, 169-274.

Hartmann-Schröder, G. (1977). Polychaeten aus dem Sublitoral und Bathyal vor der portugiesischen und marokkanischen Küste. Auswertung der Fahrt 8 (1967) von F.S. "Meteor". "Meteor" ForschungsErgebnisse D, 26, 65-99.

Hartmann-Schröder, G. (1979). Zur Kenntnis des Eulitorals der australischen Küsten unter besonderer Berücksichtigung der Polychaeten und Ostracoden. Teil I und Teil III. Mitteilungen aus dem Hamburgischen Zoologischen Museum und Institut, 76, 75-218.

Hartmann-Schröder, G. (1996). Annelida, Borstenwürmer, Polychaeta. Die Tierwelt Deutschlands, 58, 1-648.

Hartmann-Schröder, G., \& Parker, S. A. (1995). Four new species of the family Opheliidae (Polychaeta) from southern Australia. Records of the South Australian Museum, 28, 1-12.

Hartmann-Schröder, G., \& Rosenfeldt, P. (1989). Die Polychaeten der "Polarstern"-Reise ANT III/2 in die Antarktis 1984. Teil 2: Cirratulidae bis Serpulidae. Mitteilungen aus dem Hamburgischen Zoologischen Museum und Institut, 86, 65-106.

Helgason, G. V., Gardarsson, A., Svavarsson, J., Adalsteinsdottir, K., \& Gudmundsson, H. (1990). Polychaetes new to the Icelandic fauna, with remarks on some previously recorded species. Sarsia, 75, 203-212.

Hutchings, P. (2000). Family Opheliidae. In P. L. Beesley, G. J. B. Ross, \& C. J. Glasby (Eds.), Polychaetes \& allies: the southern synthesis. Fauna of Australia, vol. 4A Polychaeta, Myzostomida, Pogonophora, Echiura, Sipuncula (pp. 76-79). Melbourne: CSIRO Publishing.

Hutchings, P., \& Murray, A. (1984). Taxonomy of polychaetes from Hawkesbury River and the southern estuaries of New South Wales, Australia. Records of the Australian Museum, 36(suppl. 3), 1-119.

Kinberg, J. G. H. (1866). Annulata nova. Öfversigt af Kongliga Vetenskaps-Akademiens Förhandlingar, 22, 239-258.

Kirkegaard, J. B. (1996). Bathyal and abyssal polychaetes (sedentary species I). Galathea Reports, 17, 57-78. 
Kirkegaard, J. B. (2001). Polychaetes of the families Glyceridae, Goniadidae, and Nereididae from the North Atlantic around Iceland. Sarsia, 86, 13-20.

Kröncke, I. (1998). Macrofauna communities in the Amundsen Basin, at the Morris Jesup Rise and at the Yermak Plateau (Eurasian Arctic Ocean). Polar Biology, 19, 383-392.

Kükenthal, W. (1887). Die Opheliaceen der Expedition der Vettore Pisani. Jenaische Zeitschrift für Naturwissenschaft, 21, 361-373.

Levenstein, R. J. (1978). Annelida (Polychaeta) from the deep waters of the Pacific region of the Antarctic. Trudy Instituta Okeanologii Imeni P. P. Sirsova / Akademiya Nauk SSSR, 113, 73-88.

Levin, L., \& Gooday, A. J. (2003). The Atlantic. In P. A. Tyler (Ed.), Ecosystems of the world: the deep sea (pp. 111-178). Amsterdam: Elsevier.

Maciolek, N., \& Blake, J. (2006). Opheliidae (Polychaeta) collected by the R/V Hero and the USNS Eltanin cruises from the Southern Ocean and South America. Scientia Marina, 70, 101-113.

Malmberg, S.-A., \& Valdimarsson, H. (2003). Hydrographic conditions in Icelandic waters, 1990-1999. ICES Marine Science Symposia, 219, 50-60.

Martínez, J., \& Adarraga, I. (2001). Distribución batimétrica de comunidades macrobentónicas de sustrato blando en la plataforma continental de Guipúzcoa (golfo de Vizcaya). Boletín del Instituto Español de Oceanografía, 17, 33-48.

Maurer, D., \& Williams, S. (2007). Deep-Sea polychaetous Annelida from Central America to the Antarctic Peninsula and South Sandwich Islands. International Review of Hydrobiology, 73, 659-701.

McIntosh, W. C. (1878). On the Annelida obtained during the cruise of H.M.S. "Valorous" to Davis Strait in 1875. Transactions of the Linnean Society of London, 2nd Series / Zoology, 1, 499-511.

McIntosh, W. C. (1908). A monograph of the British annelids, vol. 2, pt. 1. Polychaeta. Nephthyidae to Syllidae. London: The Ray Society.

Monro, C. C. A. (1930). Polychaete worms, I. Reports of the "Discovery”. Expedition, 2, 1-122.

Örsted, A. S. (1843). Annulatorum danicorum conspectus. Fasc. 1. Maricolae. Copenhagen ("Hafniae”): Librariae Wahlianae.

Parapar, J. (2003). Oweniidae (Annelida, Polychaeta) from Icelandic waters, collected by the BIOICE project, with the description of Myrioglobula islandica n. sp. Sarsia, 69, 274-290.

Parapar, J. (2006). The genera Myriochele and Myrioglobula (Polychaeta, Oweniidae) in Icelandic waters with the revision of type material of Myriochele heeri Malmgren, 1867, and the description of a new species. Journal of Natural History, 40, 523-547.

Parapar, J., Besteiro, C., \& Urgorri, V. (1996). Inventario dos poliquetos (Annelida: Polychaeta) de Galicia. Cadernos da Área de Ciencias Biolóxicas (Inventarios). Seminario de Estudos Galegos, 16, 1-178.

Parapar, J., \& Moreira, J. (2008). Sobre la presencia del genero Ophelina Ørsted, 1843 (Polychaeta, Opheliidae) en el litoral de la península Ibérica. Nova Acta Científica Compostelana (Bioloxía), 17, 117134.

Parapar, J., \& Moreira, J. (2009). Polychaeta of the 'DIVA-Artabria I' project (cruise 2002) in the continental shelf and upper slope off Galicia (NW Spain). Cahiers de Biologie Marine, 50, 57-78.

Pettibone, M. (1954). Marine polychaete worms from Point Barrow, Alaska, with additional records from the North Atlantic and North Pacific. Proceedings of the United States National Museum, 103, 203-356.

Pillai, G. (1961). Annelida polychaeta of Tambalagam Lake, Ceylon. Ceylon Journal of Science (Biological Sciences), 4, 1-40.

Purschke, G. (2005). Sense organs in polychaetes. In T. Bartholomaeus \& G. Purschke (Eds.), Morphology, molecules, evolution and phylogeny in Polychaeta and related taxa. Dordrecht: Springer.

Rathke, H. (1843). Beiträge zur Fauna Norwegens. Nova Acta der Kaiserlich-Leopoldinisch-Carolinischen Deutschen Akademie der Naturforscher. Halle, 20, 1-264.

Riser, N. (1987). Observations on the genus Ophelia (Polychaeta: Opheliidae) with the description of a new species. Ophelia, 28, 11-29.

Rouse, G. (2001). Chapter 8, Opheliidae Malmgren, 1867. In G. W. Rouse \& F. Pleijel (Eds.), Polychaetes (pp. 53-56). Oxford: Oxford University Press.

Rowe, G., 2010. A provisional guide to the family Opheliidae (Polychaeta) from the shallow waters of the British Isles. Southampton: Emu 
Ltd. http://www.nmbaqcs.org/media/9790/provisional\%20guide\%20to\%20opheliidae,\%202010.pdf.

Accessed 18 March 2011.

Rowe, G. T., Polloni, P. T., \& Haedrich, R. L. (1982). The deep-sea macrobenthos on the continental margin of the northwest Atlantic Ocean. Deep-Sea Research Part A, 29, 257-278.

Salazar-Vallejo, S. I., \& Londoño-Mesa, M. H. (2004). Lista de especies y bibliografía de poliquetos (Polychaeta) del Pacífico Oriental tropical. Anales del Instituto de Biología, Universidad Nacional Autónoma de México. Serie Zoológica, 75, 9-97.

Sanfilippo, R. (2001). Bathyvermilia islandica (Polychaeta, Serpulidae): new species from the southern Icelandic Sea. Sarsia, 86, 177-182.

Santos, C. S. G., Nonato, E. F., \& Petersen, M. E. (2004). Two new species of Opheliidae (Annelida: Polychaeta): Euzonus papillatus sp. n. from a northeastern Brazilian sandy beach and Euzonus mammillatus sp. n. from the continental shelf of southeastern Brazil. Zootaxa, 478, 1-12.

Sardá, R., Gil, J., Taboada, S., \& Gili, J. M. (2009). Polychaete species captured in sediment traps moored in northwestern Mediterranean submarine canyons. Zoological Journal of the Linnean Society, 155, 1-21.

Savigny, J., -C. (1822). Systèmes des annélides, principalement des celles des cotes de l'Egypte et de la Syrie. In: Description de l'Égypte, Histoire Naturelle, vol 1 (3) (ed. M.J.L. Savigny), pp. 1-128, Paris.

Schuchert, P. (2000). Hydrozoa (Cnidaria) of Iceland collected by the BIOICE programme. Sarsia, 85, 411438.

Schüller, M. (2008). New polychaete species collected during the expeditions ANDEEP I, II, and III to the deep Atlantic sector of the Southern Ocean in the austral summers 2002 and 2005 - Ampharetidae, Opheliidae, and Scalibregmatidae. Zootaxa, 1705, 51-68.

Schüller, M., \& Ebbe, B. (2007). Global distributional patterns of selected deep-sea Polychaeta (Annelida) from the Southern Ocean. Deep-Sea Research II, 54, 1737-1751.

Sene-Silva, G. (2007). Filogenia de Opheliidae (Annelida: Polychaeta). PhD thesis. Curitiba: Universidade Federal do Paraná. [available at: http://dspace.c3sl.ufpr.br/dspace/handle/1884/12922]

Sigvaldadóttir, E. (2002). Polychaetes of the genera Prionospio and Aurospio (Spionidae, Polychaeta) from Icelandic waters. Sarsia, 87, 207-215.

Southern, R. (1914). Clare Island survey. Archiannelida and Polychaeta. Proceedings of the Royal Irish Academy, 31, 1-160.

Støp-Bowitz, C. (1945). Les Ophéliens Norvégiens. Meddelelser fra Zoologiske Museum, Oslo, 52, 21-61.

Støp-Bowitz, C. (1948). Sur les polychètes arctiques des familles des Glycériens, des Ophéliens, des Scalibregmiens et des Flabelligériens. Tromsø Museums Årshefter, 66, 3-58.

Støp-Bowitz, C. (1958). Polihetaj novavoj el Norvegujo. In Sciencaj Studoj (pp. 213-216). Copenhagen ("Kopenhago"): Internacia Scienca Asocio Esperantista.

Tebble, N. (1952). On three species of the genus Ophelia (Polychaeta) from British and adjacent waters. Annals \& Magazine of Natural History, Series, 12(5), 553-571.

Tebble, N. (1953). A review of the genus Ophelia (Polychaeta) with descriptions of new species from South African and Californian waters. Annals \& Magazine of Natural History, Series, 12(6), 361-368.

Uebelacker, J. M. (1984). Family Opheliidae. In J. M. Uebelacker \& P. G. Johnston (Eds.), Taxonomic guide to the polychaetes of the northern Gulf of Mexico, vol. 3 (pp. 17-1-17-15). Mobile: Barry A. Vittor and Ass., Inc.

Volckaert, F. (1987). Spatial pattern of soft-bottom Polychaeta off Nova Scotia, Canada. Marine Biology, 93, $627-639$.

Wehe, T., \& Fiege, D. (2003). Annotated checklist of the polychaete species of the seas surrounding the Arabian Peninsula: Red Sea, Gulf of Aden, Arabian Sea, Gulf of Oman, Arabian Gulf. Fauna of Arabia, 19, 7-238.

Weisshappel, J. B. (2000). Distribution and diversity of the hyperbenthic amphipod family Eusiridae in the different seas around the Greenland-Iceland-Faeroe-Ridge. Sarsia, 85, 227-236.

Weisshappel, J. B. (2001). Distribution and diversity of the hyperbenthic amphipod family Calliopiidae in the different seas around the Greenland-Iceland-Faeroe-Ridge. Sarsia, 86, 143-151.

Wesenberg-Lund, E. (1950). The Polychaeta of West Greenland with special reference to the fauna of Nordre Strømfjord, Kvane-, and Bredefjord. Meddelelser om Grønland, 151, 5-169.

Wesenberg-Lund, E. (1951). Polychaeta. The Zoology of Iceland, 2, 1-182. 
Wesenberg-Lund, E. (1953). The zoology of East Greenland. Polychaeta. Meddelelser om Grønland, 122, 1 169.

Weslawski, J. M., Wlodarska-Kowalczuk, M., \& Legezynska, J. (2003). Occurrence of soft bottom macrofauna along the depth gradient in High Arctic, $79^{\circ}$ N. Polish Polar Research, 24, 73-88.

Wirén, A. (1901). Ueber die waehrend der schwedischen arktischen Expedition von 1898 und 1900 eingesammelten Anneliden. Zoologischer Anzeiger, 24, 253.

\section{Supplementary material}

\begin{tabular}{|c|c|c|c|c|c|c|c|}
\hline TAXON & Sample & Specs & Date & Latitude $\mathbf{N}$ & Longitude W & Depth $(m)$ & Temp (ㄷ) \\
\hline Ammotrypanella cf. arctica & & & & & & & \\
\hline $\begin{array}{l}\text { Mclntosh, } 1878 \\
\text { Ammotrypanella cf. arctica }\end{array}$ & 2027 & 1 & 23.07.91 & 67ำ11'82" & $13 \div 20^{\prime} 58^{\prime \prime}$ & 1648 & -0.76 \\
\hline $\begin{array}{l}\text { Mclntosh, } 1878 \\
\text { Ammotrypanella cf. arctica }\end{array}$ & 2077 & 2 & 03.07.92 & 67ㅇ4'51" & $17010^{\prime} 38^{\prime \prime}$ & 1048 & -0.52 \\
\hline $\begin{array}{l}\text { McIntosh, } 1878 \\
\text { Ammotrypanella cf. arctica }\end{array}$ & 2257 & 28 & 05.09 .92 & 6314'61" & $26 \div 29 ' 14^{\prime \prime}$ & 1209 & 4.09 \\
\hline $\begin{array}{l}\text { McIntosh, } 1878 \\
\text { Ammotrypanella cf. arctica }\end{array}$ & 2310 & 116 & 11.09 .92 & 6334'09" & $22 \circ 42^{\prime} 73^{\prime \prime}$ & 172 & 7.30 \\
\hline $\begin{array}{l}\text { Mclntosh, } 1878 \\
\text { Ammotrypanella cf. arctica }\end{array}$ & 2403 & 12 & 01.07 .93 & 630' $90^{\prime \prime}$ & 21여'60" & 838 & 5.49 \\
\hline $\begin{array}{l}\text { Mclntosh, } 1878 \\
\text { Ammotrypanella cf. arctica }\end{array}$ & 2404 & 1 & 01.07 .93 & 630'ㅇ' & 21 응' $80^{\prime \prime}$ & 802 & 5.49 \\
\hline $\begin{array}{l}\text { Mclntosh, } 1878 \\
\text { Ammotrypanella cf. arctica }\end{array}$ & 2406 & 6 & 01.07 .93 & $62 \div 59 ' 20^{\prime \prime}$ & 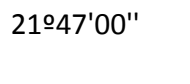 & 934 & 4.57 \\
\hline $\begin{array}{l}\text { McIntosh, } 1878 \\
\text { Ammotrypanella cf. arctica }\end{array}$ & 2410 & 2 & 02.07 .93 & $62 \div 51^{\prime} 60^{\prime \prime}$ & 21ㅇ4'10" & 1074 & 4.00 \\
\hline $\begin{array}{l}\text { McIntosh, } 1878 \\
\text { Ammotrypanella cf. arctica }\end{array}$ & 2415 & 7 & 02.07 .93 & $63 \div 00 ' 18^{\prime \prime}$ & $21900 ' 54^{\prime \prime}$ & 819 & 5.36 \\
\hline $\begin{array}{l}\text { Mclntosh, } 1878 \\
\text { Ammotrypanella cf. arctica }\end{array}$ & 2429 & 1 & 03.07 .93 & $63 \div 07^{\prime} 00^{\prime \prime}$ & $19 \div 56^{\prime} 60^{\prime \prime}$ & 1072 & 4.80 \\
\hline $\begin{array}{l}\text { Mclntosh, } 1878 \\
\text { Ammotrypanella cf. arctica }\end{array}$ & 2430 & 1 & 03.07.93 & 630' $90^{\prime \prime}$ & $19-57^{\prime} 20^{\prime \prime}$ & 1016 & 4.80 \\
\hline $\begin{array}{l}\text { Mclntosh, } 1878 \\
\text { Ammotrypanella cf. arctica }\end{array}$ & 2475 & 2 & 05.07 .93 & 630'ㅇ" & 21ำ34'90" & 842 & 5.54 \\
\hline $\begin{array}{l}\text { Mclntosh, } 1878 \\
\text { Ammotrypanella cf. arctica }\end{array}$ & 2514 & 1 & 13.07 .93 & $66 \div 34^{\prime} 08^{\prime \prime}$ & $25 \div 13^{\prime} 68^{\prime \prime}$ & 465 & -0.34 \\
\hline $\begin{array}{l}\text { McIntosh, } 1878 \\
\text { Ammotrypanella cf. arctica }\end{array}$ & 2697 & 9 & 02.09 .94 & 641'ㅇ' & $2743^{\prime} 10^{\prime \prime}$ & 1042 & 4.20 \\
\hline $\begin{array}{l}\text { Mclntosh, } 1878 \\
\text { Ammotrypanella cf. arctica }\end{array}$ & 2698 & 1 & 02.09 .94 & 641ㅇ'50" & $27 \circ 42^{\prime} 60^{\prime \prime}$ & 1038 & 4.20 \\
\hline $\begin{array}{l}\text { McIntosh, } 1878 \\
\text { Ammotrypanella cf. arctica }\end{array}$ & 2700 & 8 & 02.09 .94 & $64 \div 05 ' 60^{\prime \prime}$ & 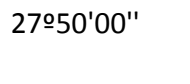 & 1105 & 3.84 \\
\hline $\begin{array}{l}\text { McIntosh, } 1878 \\
\text { Ammotrypanella cf. arctica }\end{array}$ & 2701 & 37 & 02.09 .94 & 640'ㄷ' & 27ㅇ4' $70^{\prime \prime}$ & 1121 & 3.84 \\
\hline $\begin{array}{l}\text { Mclntosh, } 1878 \\
\text { Ammotrypanella cf. arctica }\end{array}$ & 2704 & 16 & 02.09 .94 & $63 \div 50^{\prime} 50^{\prime \prime}$ & 27ㅇ4' $80^{\prime \prime}$ & 1295 & 3.80 \\
\hline $\begin{array}{l}\text { McIntosh, } 1878 \\
\text { Ammotrypanella cf. arctica }\end{array}$ & 2706 & 6 & 03.09 .94 & $63 \div 55^{\prime} 80^{\prime \prime}$ & 2816'30" & 1406 & 3.71 \\
\hline $\begin{array}{l}\text { Mclntosh, } 1878 \\
\text { Ammotrypanella cf. arctica }\end{array}$ & 2707 & 8 & 03.09.94 & 635'ㅇ' & 2816'80" & 1407 & 3.71 \\
\hline $\begin{array}{l}\text { Mclntosh, } 1878 \\
\text { Ammotrypanella cf. arctica }\end{array}$ & 2773 & 1 & 03.08 .95 & 6914'89" & 14ㅇ16'52" & 1629 & -0.86 \\
\hline $\begin{array}{l}\text { Mclntosh, } 1878 \\
\text { Ammotrypanella cf. arctica }\end{array}$ & 2777 & 1 & 03.08.95 & $68 \div 36^{\prime} 80^{\prime \prime}$ & $14 \div 40^{\prime} 70^{\prime \prime}$ & 1556 & -0.78 \\
\hline $\begin{array}{l}\text { Mclntosh, } 1878 \\
\text { Ammotrypanella cf. arctica }\end{array}$ & 2859 & 38 & 29.08 .95 & $61 \div 50 ' 22^{\prime \prime}$ & $16-52^{\prime} 86^{\prime \prime}$ & 2270 & 2.37 \\
\hline McIntosh, 1878 & 2860 & 63 & 30.08 .95 & 614'43" & $16-57^{\prime} 48^{\prime \prime}$ & 2295 & 2.60 \\
\hline
\end{tabular}




\begin{tabular}{|c|c|c|c|c|c|c|c|}
\hline Ammotrypanella cf. arctica & & & & & & & \\
\hline $\begin{array}{l}\text { Mclntosh, } 1878 \\
\text { Ammotrypanella cf. arctica }\end{array}$ & 2863 & 30 & 30.08 .95 & 611''ㅇ" & $18 \div 02^{\prime} 57^{\prime \prime}$ & 2400 & 2.07 \\
\hline $\begin{array}{l}\text { Mclntosh, } 1878 \\
\text { Ammotrypanella cf. arctica }\end{array}$ & 2903 & 4 & 24.08 .96 & $65 \div 22^{\prime} 80^{\prime \prime}$ & $28920^{\prime} 63^{\prime \prime}$ & 1066 & 4.78 \\
\hline $\begin{array}{l}\text { McIntosh, } 1878 \\
\text { Ammotrypanella cf. arctica }\end{array}$ & 2908 & 8 & 25.08 .96 & $65 \div 15^{\prime} 67^{\prime \prime}$ & $28 \div 50 ' 27 "$ & 1301 & 3.96 \\
\hline $\begin{array}{l}\text { Mclntosh, } 1878 \\
\text { Ammotrypanella cf. arctica }\end{array}$ & 2912 & 5 & 25.08 .96 & 6511'01" & 29o04'18" & 1456 & 3.90 \\
\hline $\begin{array}{l}\text { McIntosh, } 1878 \\
\text { Ammotrypanella cf. arctica }\end{array}$ & 3012 & 19 & 07.07.97 & $6122^{\prime} 20^{\prime \prime}$ & 15ㅇํ' & 2133 & 3.29 \\
\hline $\begin{array}{l}\text { McIntosh, } 1878 \\
\text { Ammotrypanella cf. arctica }\end{array}$ & 3072 & 1 & 12.07 .97 & $61053^{\prime} 65^{\prime \prime}$ & $15 \div 08^{\prime} 15^{\prime \prime}$ & 2082 & 2.83 \\
\hline $\begin{array}{l}\text { McIntosh, } 1878 \\
\text { Ammotrypanella cf. arctica }\end{array}$ & 3073 & 9 & 12.07 .97 & 61으' $78^{\prime \prime}$ & $15 \div 08^{\prime} 33^{\prime \prime}$ & 2083 & 2.83 \\
\hline $\begin{array}{l}\text { McIntosh, } 1878 \\
\text { Ammotrypanella cf. arctica }\end{array}$ & 3075 & 4 & 13.07 .97 & $62^{\circ} 00^{\prime} 19^{\prime \prime}$ & 1559'97" & 2192 & 3.07 \\
\hline $\begin{array}{l}\text { McIntosh, } 1878 \\
\text { Ammotrypanella cf. arctica }\end{array}$ & 3161 & 5 & 25.07 .00 & $62 \div 37^{\prime} 08^{\prime \prime}$ & 2321'79" & 1250 & 3.61 \\
\hline $\begin{array}{l}\text { McIntosh, } 1878 \\
\text { Ammotrypanella cf. arctica }\end{array}$ & 3167 & 12 & 26.07 .00 & $60 \div 54 ' 88 "$ & $22 \div 47^{\prime} 26^{\prime \prime}$ & 1897 & 2.98 \\
\hline $\begin{array}{l}\text { McIntosh, } 1878 \\
\text { Ammotrypanella cf. arctica }\end{array}$ & 3173 & 1 & 28.07 .00 & $60 \circ 05^{\prime} 38^{\prime \prime}$ & $20-51 ' 23^{\prime \prime}$ & 2709 & 2.68 \\
\hline $\begin{array}{l}\text { McIntosh, } 1878 \\
\text { Ammotrypanella cf. arctica }\end{array}$ & 3204 & 75 & 08.07.01 & 64이'1" & 7ㅇ5'56" & 2613 & -0.83 \\
\hline $\begin{array}{l}\text { McIntosh, } 1878 \\
\text { Ammotrypanella cf. arctica }\end{array}$ & 3208 & 75 & 09.07.01 & 6543'93" & 7으'95" & 2002 & -0.87 \\
\hline $\begin{array}{l}\text { Mclntosh, } 1878 \\
\text { Ammotrypanella cf. arctica }\end{array}$ & 3210 & 54 & 09.07.01 & 66o13'66" & 6-51'77" & 2544 & -0.87 \\
\hline $\begin{array}{l}\text { Mclntosh, } 1878 \\
\text { Ammotrypanella cf. arctica }\end{array}$ & 3214 & 695 & 10.07.01 & 67웅' & 6011'83" & 3003 & -0.90 \\
\hline $\begin{array}{l}\text { Mclntosh, } 1878 \\
\text { Ammotrypanella cf. arctica }\end{array}$ & 3216 & 56 & 11.07 .01 & 6705'86" & 7윽'12" & 2014 & -0.86 \\
\hline $\begin{array}{l}\text { McIntosh, } 1878 \\
\text { Ammotrypanella cf. arctica }\end{array}$ & 3219 & 35 & 11.07 .01 & 67ㅇ14'79" & 828'06" & 1642 & -0.82 \\
\hline $\begin{array}{l}\text { McIntosh, } 1878 \\
\text { Ammotrypanella cf. arctica }\end{array}$ & 3222 & 3 & 11.07 .01 & 67ㅇ5'77" & 805'94" & 1525 & -0.83 \\
\hline $\begin{array}{l}\text { Mclntosh, } 1878 \\
\text { Ammotrypanella cf. arctica }\end{array}$ & 3504 & 1 & 02.09 .02 & $62^{\circ} 01^{\prime} 46^{\prime \prime}$ & 1949'15" & 1733 & 3.09 \\
\hline $\begin{array}{l}\text { McIntosh, } 1878 \\
\text { Ammotrypanella cf. arctica }\end{array}$ & 3509 & 7 & 03.09.02 & $62 \circ 02^{\prime} 40^{\prime \prime}$ & 1938'71" & 1678 & 2.70 \\
\hline $\begin{array}{l}\text { McIntosh, } 1878 \\
\text { Ammotrypanella cf. arctica }\end{array}$ & 3514 & 1 & 04.09 .02 & $62 \div 25^{\prime} 59^{\prime \prime}$ & 1946'15" & 1780 & 2.93 \\
\hline $\begin{array}{l}\text { McIntosh, } 1878 \\
\text { Ammotrypanella cf. arctica }\end{array}$ & 3570 & 4 & 04.09 .03 & 6342'71" & 29o10'36" & 1819 & 3.24 \\
\hline $\begin{array}{l}\text { McIntosh, } 1878 \\
\text { Ammotrypanella cf. arctica }\end{array}$ & 3573 & 2 & 05.09 .03 & $63 \div 22^{\prime} 49^{\prime \prime}$ & 29o54'85" & 2359 & 3.06 \\
\hline $\begin{array}{l}\text { Mclntosh, } 1878 \\
\text { Ammotrypanella cf. arctica }\end{array}$ & 3621 & 4 & 14.07 .04 & 6629'39" & $9 \div 44 ' 80^{\prime \prime}$ & 1475 & -0.78 \\
\hline $\begin{array}{l}\text { McIntosh, } 1878 \\
\text { Ammotrypanella cf. arctica }\end{array}$ & 3624 & 19 & 14.07 .04 & $66059^{\prime} 48^{\prime \prime}$ & $8 \div 48^{\prime} 73^{\prime \prime}$ & 1628 & -0.82 \\
\hline $\begin{array}{l}\text { McIntosh, } 1878 \\
\text { Ammotrypanella cf. arctica }\end{array}$ & 3628 & 15 & 15.07 .04 & 67ㅇ19'53" & 932'76" & 1609 & -0.81 \\
\hline $\begin{array}{l}\text { McIntosh, } 1878 \\
\text { Ammotrypanella cf. arctica }\end{array}$ & 3632 & 100 & 16.07 .04 & 6800'92" & 914'78" & 1727 & -0.82 \\
\hline $\begin{array}{l}\text { Mclntosh, } 1878 \\
\text { Ammotrypanella cf. arctica }\end{array}$ & 3633 & 191 & 17.07.04 & $68 \div 25^{\prime} 12^{\prime \prime}$ & $8 \div 57^{\prime} 72^{\prime \prime}$ & 1952 & -0.84 \\
\hline $\begin{array}{l}\text { McIntosh, } 1878 \\
\text { Ammotrypanella cf. arctica }\end{array}$ & 3636 & 7 & 17.07 .04 & 6849'71" & 914'42" & 1844 & -0.81 \\
\hline $\begin{array}{l}\text { Mclntosh, } 1878 \\
\text { Ammotrypanella cf. arctica }\end{array}$ & 3637 & 175 & 17.07.04 & 6826'92" & $10 \circ 08^{\prime} 75^{\prime \prime}$ & 2069 & -0.80 \\
\hline $\begin{array}{l}\text { McIntosh, } 1878 \\
\text { Ammotrypanella cf. arctica }\end{array}$ & 3638 & 1 & 18.07.04 & $68 \div 26^{\prime} 63^{\prime \prime}$ & 1010'58" & 2065 & -0.80 \\
\hline Mclntosh, 1878 & 3640 & 120 & 18.07.04 & 67ㅇ5'63" & $10 \circ 02^{\prime} 61^{\prime \prime}$ & 1915 & -0.82 \\
\hline
\end{tabular}




\begin{tabular}{|c|c|c|c|c|c|c|c|}
\hline Ammotrypanella cf. arctica & & & & & & & \\
\hline $\begin{array}{l}\text { Mclntosh, } 1878 \\
\text { Ammotrypanella cf. arctica }\end{array}$ & 3645 & 12 & 21.07 .04 & $67 \div 24^{\prime} 22^{\prime \prime}$ & $10 \div 40^{\prime} 59^{\prime \prime}$ & 1703 & -0.81 \\
\hline $\begin{array}{l}\text { Mclntosh, } 1878 \\
\text { Ammotrypanella cf. arctica }\end{array}$ & 3648 & 41 & 22.07 .04 & $68957^{\prime} 10^{\prime \prime}$ & $10932^{\prime} 80^{\prime \prime}$ & 2215 & -0.79 \\
\hline $\begin{array}{l}\text { McIntosh, } 1878 \\
\text { Ammotrypanella cf. arctica }\end{array}$ & 3649 & 9 & 22.07 .04 & $68 \div 56^{\prime} 45^{\prime \prime}$ & $10035^{\prime} 65^{\prime \prime}$ & 2214 & -0.79 \\
\hline $\begin{array}{l}\text { Mclntosh, } 1878 \\
\text { Ammotrypanella cf. arctica }\end{array}$ & 3652 & 146 & 22.07 .04 & 690'00" & $13033^{\prime} 85^{\prime \prime}$ & 1678 & -0.81 \\
\hline $\begin{array}{l}\text { McIntosh, } 1878 \\
\text { Ammotrypanella cf. arctica }\end{array}$ & 2027 & 1 & 23.07 .91 & 67ำ1'82" & $13 \div 20 ' 58 "$ & 1648 & -0.76 \\
\hline $\begin{array}{l}\text { McIntosh, } 1878 \\
\text { Ammotrypanella cf. arctica }\end{array}$ & 2077 & 2 & 03.07 .92 & $67 \div 40^{\prime} 51^{\prime \prime}$ & 17웅'38" & 1048 & -0.52 \\
\hline $\begin{array}{l}\text { McIntosh, } 1878 \\
\text { Ammotrypanella cf. arctica }\end{array}$ & 2257 & 28 & 05.09 .92 & 6314'61" & 26029'14" & 1209 & 4.09 \\
\hline $\begin{array}{l}\text { McIntosh, } 1878 \\
\text { Ammotrypanella cf. arctica }\end{array}$ & 2310 & 116 & 11.09 .92 & 6334'09" & $22 \div 42^{\prime} 73^{\prime \prime}$ & 172 & 7.30 \\
\hline $\begin{array}{l}\text { McIntosh, } 1878 \\
\text { Ammotrypanella cf. arctica }\end{array}$ & 2403 & 12 & 01.07 .93 & 630' $90^{\prime \prime}$ & 21ㄴㅇ'60" & 838 & 5.49 \\
\hline $\begin{array}{l}\text { McIntosh, } 1878 \\
\text { Ammotrypanella cf. arctica }\end{array}$ & 2404 & 1 & 01.07 .93 & $63 \div 02^{\prime} 30^{\prime \prime}$ & $21950 ' 80^{\prime \prime}$ & 802 & 5.49 \\
\hline $\begin{array}{l}\text { McIntosh, } 1878 \\
\text { Ammotrypanella cf. arctica }\end{array}$ & 2406 & 6 & 01.07 .93 & $62 \div 59^{\prime} 20^{\prime \prime}$ & $2147^{\prime} 00^{\prime \prime}$ & 934 & 4.57 \\
\hline $\begin{array}{l}\text { McIntosh, } 1878 \\
\text { Ammotrypanella cf. arctica }\end{array}$ & 2410 & 2 & 02.07 .93 & $62 \div 51^{\prime} 60^{\prime \prime}$ & 21ㅇㄴ'10" & 1074 & 4.00 \\
\hline $\begin{array}{l}\text { Mclntosh, } 1878 \\
\text { Ammotrypanella cf. arctica }\end{array}$ & 2415 & 7 & 02.07.93 & $63 \div 00 ' 18^{\prime \prime}$ & 21ㅇo'54" & 819 & 5.36 \\
\hline $\begin{array}{l}\text { Mclntosh, } 1878 \\
\text { Ammotrypanella cf. arctica }\end{array}$ & 2429 & 1 & 03.07 .93 & $63 \div 07^{\prime} 00^{\prime \prime}$ & $19-566^{\prime} 60^{\prime \prime}$ & 1072 & 4.80 \\
\hline $\begin{array}{l}\text { Mclntosh, } 1878 \\
\text { Ammotrypanella cf. arctica }\end{array}$ & 2430 & 1 & 03.07 .93 & 630ㄱ'90" & $19-57 ' 20^{\prime \prime}$ & 1016 & 4.80 \\
\hline $\begin{array}{l}\text { McIntosh, } 1878 \\
\text { Ammotrypanella cf. arctica }\end{array}$ & 2475 & 2 & 05.07 .93 & $63 \div 04 ' 20^{\prime \prime}$ & 21ㅇ'ㅇ' & 842 & 5.54 \\
\hline $\begin{array}{l}\text { McIntosh, } 1878 \\
\text { Ammotrypanella cf. arctica }\end{array}$ & 2514 & 1 & 13.07 .93 & $66034 ' 08^{\prime \prime}$ & 2513'68" & 465 & -0.34 \\
\hline $\begin{array}{l}\text { McIntosh, } 1878 \\
\text { Ammotrypanella cf. arctica }\end{array}$ & 2697 & 9 & 02.09 .94 & 6410'20" & 27여'10" & 1042 & 4.20 \\
\hline $\begin{array}{l}\text { Mclntosh, } 1878 \\
\text { Ammotrypanella cf. arctica }\end{array}$ & 2698 & 1 & 02.09 .94 & $64 \div 10^{\prime} 50^{\prime \prime}$ & $27 \div 42^{\prime} 60^{\prime \prime}$ & 1038 & 4.20 \\
\hline $\begin{array}{l}\text { McIntosh, } 1878 \\
\text { Ammotrypanella cf. arctica }\end{array}$ & 2700 & 8 & 02.09 .94 & 6405'60" & 27ㅇ5ㅇ'00" & 1105 & 3.84 \\
\hline $\begin{array}{l}\text { McIntosh, } 1878 \\
\text { Ammotrypanella cf. arctica }\end{array}$ & 2701 & 37 & 02.09 .94 & $64 \div 05^{\prime} 50^{\prime \prime}$ & 27ㅇ4'70" & 1121 & 3.84 \\
\hline $\begin{array}{l}\text { McIntosh, } 1878 \\
\text { Ammotrypanella cf. arctica }\end{array}$ & 2704 & 16 & 02.09 .94 & $63 \div 50 ' 50 "$ & 27ㅇ42'80" & 1295 & 3.80 \\
\hline $\begin{array}{l}\text { McIntosh, } 1878 \\
\text { Ammotrypanella cf. arctica }\end{array}$ & 2706 & 6 & 03.09 .94 & $63 \div 55^{\prime} 80^{\prime \prime}$ & 2816'30" & 1406 & 3.71 \\
\hline $\begin{array}{l}\text { McIntosh, } 1878 \\
\text { Ammotrypanella cf. arctica }\end{array}$ & 2707 & 8 & 03.09 .94 & $63 \div 55 ' 30 "$ & 2816'80" & 1407 & 3.71 \\
\hline $\begin{array}{l}\text { McIntosh, } 1878 \\
\text { Ammotrypanella cf. arctica }\end{array}$ & 2773 & 1 & 03.08 .95 & 6914'89" & $14^{\circ} 16^{\prime} 52^{\prime \prime}$ & 1629 & -0.86 \\
\hline $\begin{array}{l}\text { McIntosh, } 1878 \\
\text { Ammotrypanella cf. arctica }\end{array}$ & 2777 & 1 & 03.08 .95 & $68 \div 36^{\prime} 80^{\prime \prime}$ & $14 \div 40^{\prime} 70^{\prime \prime}$ & 1556 & -0.78 \\
\hline $\begin{array}{l}\text { McIntosh, } 1878 \\
\text { Ammotrypanella cf. arctica }\end{array}$ & 2859 & 38 & 29.08 .95 & $61950 ' 22 "$ & $16052^{\prime} 86^{\prime \prime}$ & 2270 & 2.37 \\
\hline $\begin{array}{l}\text { McIntosh, } 1878 \\
\text { Ammotrypanella cf. arctica }\end{array}$ & 2860 & 63 & 30.08 .95 & $61043^{\prime} 43^{\prime \prime}$ & $16057^{\prime} 48^{\prime \prime}$ & 2295 & 2.60 \\
\hline $\begin{array}{l}\text { McIntosh, } 1878 \\
\text { Ammotrypanella cf. arctica }\end{array}$ & 2863 & 30 & 30.08 .95 & 61ำ10'18" & $18^{\circ} 02^{\prime} 57^{\prime \prime}$ & 2400 & 2.07 \\
\hline $\begin{array}{l}\text { Mclntosh, } 1878 \\
\text { Ammotrypanella cf. arctica }\end{array}$ & 2903 & 4 & 24.08 .96 & $65 \div 22^{\prime} 80^{\prime \prime}$ & $28020^{\prime} 63^{\prime \prime}$ & 1066 & 4.78 \\
\hline $\begin{array}{l}\text { McIntosh, } 1878 \\
\text { Ammotrypanella cf. arctica }\end{array}$ & 2908 & 8 & 25.08 .96 & 6515'67" & $28 \div 50 ' 27^{\prime \prime}$ & 1301 & 3.96 \\
\hline Mclntosh, 1878 & 2912 & 5 & 25.08 .96 & 6511'01" & 290'18" & 1456 & 3.90 \\
\hline
\end{tabular}




\begin{tabular}{|c|c|c|c|c|c|c|c|}
\hline Ammotrypanella cf. arctica & & & & & & & \\
\hline $\begin{array}{l}\text { Mclntosh, } 1878 \\
\text { Ammotrypanella cf. arctica }\end{array}$ & 3012 & 19 & 07.07.97 & $61^{\circ} 22^{\prime} 20^{\prime \prime}$ & $15 \div 18^{\prime} 98^{\prime \prime}$ & 2133 & 3.29 \\
\hline $\begin{array}{l}\text { Mclntosh, } 1878 \\
\text { Ammotrypanella cf. arctica }\end{array}$ & 3072 & 1 & 12.07 .97 & $61953^{\prime} 65^{\prime \prime}$ & $15 \div 08^{\prime} 15^{\prime \prime}$ & 2082 & 2.83 \\
\hline $\begin{array}{l}\text { McIntosh, } 1878 \\
\text { Ammotrypanella cf. arctica }\end{array}$ & 3073 & 9 & 12.07.97 & $61053^{\prime} 78^{\prime \prime}$ & $15 \div 08^{\prime} 33^{\prime \prime}$ & 2083 & 2.83 \\
\hline $\begin{array}{l}\text { Mclntosh, } 1878 \\
\text { Ammotrypanella cf. arctica }\end{array}$ & 3075 & 4 & 13.07.97 & $62^{\circ} 00^{\prime} 19^{\prime \prime}$ & 1559'97" & 2192 & 3.07 \\
\hline $\begin{array}{l}\text { McIntosh, } 1878 \\
\text { Ammotrypanella cf. arctica }\end{array}$ & 3161 & 5 & 25.07 .00 & $62 \div 37^{\prime} 08^{\prime \prime}$ & 2321'79" & 1250 & 3.61 \\
\hline $\begin{array}{l}\text { McIntosh, } 1878 \\
\text { Ammotrypanella cf. arctica }\end{array}$ & 3167 & 12 & 26.07 .00 & $60 \div 54 ' 88^{\prime \prime}$ & $22 \circ 47^{\prime} 26^{\prime \prime}$ & 1897 & 2.98 \\
\hline $\begin{array}{l}\text { McIntosh, } 1878 \\
\text { Ammotrypanella cf. arctica }\end{array}$ & 3173 & 1 & 28.07 .00 & $60 \div 05 ' 38 "$ & $20 \div 51^{\prime} 23^{\prime \prime}$ & 2709 & 2.68 \\
\hline $\begin{array}{l}\text { McIntosh, } 1878 \\
\text { Ammotrypanella cf. arctica }\end{array}$ & 3204 & 75 & 08.07 .01 & 6451'71" & 7ㅇ5'ㄷ' & 2613 & -0.83 \\
\hline $\begin{array}{l}\text { McIntosh, } 1878 \\
\text { Ammotrypanella cf. arctica }\end{array}$ & 3208 & 75 & 09.07.01 & $65 \div 43^{\prime} 93^{\prime \prime}$ & 7ㅇo'95" & 2002 & -0.87 \\
\hline $\begin{array}{l}\text { McIntosh, } 1878 \\
\text { Ammotrypanella cf. arctica }\end{array}$ & 3210 & 54 & 09.07.01 & 6613'66" & 6o51'77" & 2544 & -0.87 \\
\hline $\begin{array}{l}\text { Mclntosh, } 1878 \\
\text { Ammotrypanella cf. arctica }\end{array}$ & 3214 & 695 & 10.07.01 & 6701'78" & 6011'83" & 3003 & -0.90 \\
\hline $\begin{array}{l}\text { McIntosh, } 1878 \\
\text { Ammotrypanella cf. arctica }\end{array}$ & 3216 & 56 & 11.07 .01 & 67ㅇ5'86" & 7으'12" & 2014 & -0.86 \\
\hline $\begin{array}{l}\text { McIntosh, } 1878 \\
\text { Ammotrypanella cf. arctica }\end{array}$ & 3219 & 35 & 11.07 .01 & 67ㅇ14'79" & $8 \div 28 ' 06^{\prime \prime}$ & 1642 & -0.82 \\
\hline $\begin{array}{l}\text { Mclntosh, } 1878 \\
\text { Ammotrypanella cf. arctica }\end{array}$ & 3222 & 3 & 11.07 .01 & 67ㅇ5'77" & 80'94" & 1525 & -0.83 \\
\hline $\begin{array}{l}\text { Mclntosh, } 1878 \\
\text { Ammotrypanella cf. arctica }\end{array}$ & 3504 & 1 & 02.09 .02 & $62^{\circ} 01^{\prime} 46^{\prime \prime}$ & 1949'15" & 1733 & 3.09 \\
\hline $\begin{array}{l}\text { McIntosh, } 1878 \\
\text { Ammotrypanella cf. arctica }\end{array}$ & 3509 & 7 & 03.09.02 & $62 \div 02^{\prime} 40^{\prime \prime}$ & 193'71" & 1678 & 2.70 \\
\hline $\begin{array}{l}\text { McIntosh, } 1878 \\
\text { Ammotrypanella cf. arctica }\end{array}$ & 3514 & 1 & 04.09 .02 & $62 \div 25^{\prime} 59^{\prime \prime}$ & $19-46^{\prime} 15^{\prime \prime}$ & 1780 & 2.93 \\
\hline $\begin{array}{l}\text { McIntosh, } 1878 \\
\text { Ammotrypanella cf. arctica }\end{array}$ & 3570 & 4 & 04.09 .03 & 6342'71" & 2910'36" & 1819 & 3.24 \\
\hline $\begin{array}{l}\text { Mclntosh, } 1878 \\
\text { Ammotrypanella cf. arctica }\end{array}$ & 3573 & 2 & 05.09 .03 & $63 \div 22^{\prime} 49^{\prime \prime}$ & 29-54'85" & 2359 & 3.06 \\
\hline $\begin{array}{l}\text { McIntosh, } 1878 \\
\text { Ammotrypanella cf. arctica }\end{array}$ & 3621 & 4 & 14.07 .04 & 66-29'39" & $9044 ' 80^{\prime \prime}$ & 1475 & -0.78 \\
\hline $\begin{array}{l}\text { Mclntosh, } 1878 \\
\text { Ammotrypanella cf. arctica }\end{array}$ & 3624 & 19 & 14.07.04 & $66059^{\prime} 48^{\prime \prime}$ & $8048^{\prime} 73^{\prime \prime}$ & 1628 & -0.82 \\
\hline $\begin{array}{l}\text { McIntosh, } 1878 \\
\text { Ammotrypanella cf. arctica }\end{array}$ & 3628 & 15 & 15.07 .04 & 67ㅇ19'53" & 932'76" & 1609 & -0.81 \\
\hline $\begin{array}{l}\text { McIntosh, } 1878 \\
\text { Ammotrypanella cf. arctica }\end{array}$ & 3632 & 100 & 16.07.04 & 6800'92" & 9o14'78" & 1727 & -0.82 \\
\hline $\begin{array}{l}\text { McIntosh, } 1878 \\
\text { Ammotrypanella cf. arctica }\end{array}$ & 3633 & 191 & 17.07 .04 & $68 \div 25^{\prime} 12^{\prime \prime}$ & 8익ㄹ" & 1952 & -0.84 \\
\hline $\begin{array}{l}\text { McIntosh, } 1878 \\
\text { Ammotrypanella cf. arctica }\end{array}$ & 3636 & 7 & 17.07.04 & 6849'71" & 9-14'42" & 1844 & -0.81 \\
\hline $\begin{array}{l}\text { McIntosh, } 1878 \\
\text { Ammotrypanella cf. arctica }\end{array}$ & 3637 & 175 & 17.07.04 & 68으' & $10 \circ 08^{\prime} 75^{\prime \prime}$ & 2069 & -0.80 \\
\hline $\begin{array}{l}\text { McIntosh, } 1878 \\
\text { Ammotrypanella cf. arctica }\end{array}$ & 3638 & 1 & 18.07.04 & $68 \div 26^{\prime} 63^{\prime \prime}$ & 1010'58" & 2065 & -0.80 \\
\hline $\begin{array}{l}\text { McIntosh, } 1878 \\
\text { Ammotrypanella cf. arctica }\end{array}$ & 3640 & 120 & 18.07.04 & 67ㅇ5'63" & $10 \circ 02^{\prime} 61^{\prime \prime}$ & 1915 & -0.82 \\
\hline $\begin{array}{l}\text { McIntosh, } 1878 \\
\text { Ammotrypanella cf. arctica }\end{array}$ & 3645 & 12 & 21.07 .04 & 67으'22' & $10 \circ 40^{\prime} 59^{\prime \prime}$ & 1703 & -0.81 \\
\hline $\begin{array}{l}\text { Mclntosh, } 1878 \\
\text { Ammotrypanella cf. arctica }\end{array}$ & 3648 & 41 & 22.07 .04 & $68957^{\prime} 10^{\prime \prime}$ & $10-32^{\prime} 80^{\prime \prime}$ & 2215 & -0.79 \\
\hline $\begin{array}{l}\text { McIntosh, } 1878 \\
\text { Ammotrypanella cf. arctica }\end{array}$ & 3649 & 9 & 22.07 .04 & $68 \div 56^{\prime} 45^{\prime \prime}$ & $10035^{\prime} 65^{\prime \prime}$ & 2214 & -0.79 \\
\hline Mclntosh, 1878 & 3652 & 146 & 22.07 .04 & $69 \circ 04^{\prime} 00^{\prime \prime}$ & $13 \div 33^{\prime} 85^{\prime \prime}$ & 1678 & -0.81 \\
\hline
\end{tabular}




\begin{tabular}{|c|c|c|c|c|c|c|c|}
\hline Ammotrypanella cf. arctica & & & & & & & \\
\hline $\begin{array}{l}\text { Mclntosh, } 1878 \\
\text { Ammotrypanella cf. arctica }\end{array}$ & 2027 & 1 & 23.07.91 & 67ำ11'82" & $13 \div 20^{\prime} 58^{\prime \prime}$ & 1648 & -0.76 \\
\hline $\begin{array}{l}\text { Mclntosh, } 1878 \\
\text { Ammotrypanella cf. arctica }\end{array}$ & 2077 & 2 & 03.07 .92 & $6740 ' 51^{\prime \prime}$ & $17010^{\prime} 38^{\prime \prime}$ & 1048 & -0.52 \\
\hline $\begin{array}{l}\text { McIntosh, } 1878 \\
\text { Ammotrypanella cf. arctica }\end{array}$ & 2257 & 28 & 05.09 .92 & 6314'61" & 2629'14" & 1209 & 4.09 \\
\hline $\begin{array}{l}\text { Mclntosh, } 1878 \\
\text { Ammotrypanella cf. arctica }\end{array}$ & 2310 & 116 & 11.09 .92 & 6334'09" & $22 \circ 42^{\prime} 73^{\prime \prime}$ & 172 & 7.30 \\
\hline $\begin{array}{l}\text { McIntosh, } 1878 \\
\text { Ammotrypanella cf. arctica }\end{array}$ & 2403 & 12 & 01.07 .93 & 630' $90^{\prime \prime}$ & 21여'60" & 838 & 5.49 \\
\hline $\begin{array}{l}\text { McIntosh, } 1878 \\
\text { Ammotrypanella cf. arctica }\end{array}$ & 2404 & 1 & 01.07 .93 & 630'ㅇ' & $21050^{\prime} 80^{\prime \prime}$ & 802 & 5.49 \\
\hline $\begin{array}{l}\text { McIntosh, } 1878 \\
\text { Ammotrypanella cf. arctica }\end{array}$ & 2406 & 6 & 01.07 .93 & $62 \div 59^{\prime} 20^{\prime \prime}$ & 214'00" & 934 & 4.57 \\
\hline $\begin{array}{l}\text { McIntosh, } 1878 \\
\text { Ammotrypanella cf. arctica }\end{array}$ & 2410 & 2 & 02.07 .93 & $62 \div 51^{\prime} 60^{\prime \prime}$ & 21ㄴ4'10" & 1074 & 4.00 \\
\hline $\begin{array}{l}\text { McIntosh, } 1878 \\
\text { Ammotrypanella cf. arctica }\end{array}$ & 2415 & 7 & 02.07 .93 & $63 \div 00 ' 18 "$ & 21000'54" & 819 & 5.36 \\
\hline $\begin{array}{l}\text { McIntosh, } 1878 \\
\text { Ammotrypanella cf. arctica }\end{array}$ & 2429 & 1 & 03.07 .93 & $63 \div 07^{\prime} 00^{\prime \prime}$ & $19-566^{\prime} 60^{\prime \prime}$ & 1072 & 4.80 \\
\hline $\begin{array}{l}\text { Mclntosh, } 1878 \\
\text { Ammotrypanella cf. arctica }\end{array}$ & 2430 & 1 & 03.07 .93 & 630'90" & $19 \div 57 ' 20^{\prime \prime}$ & 1016 & 4.80 \\
\hline $\begin{array}{l}\text { McIntosh, } 1878 \\
\text { Ammotrypanella cf. arctica }\end{array}$ & 2475 & 2 & 05.07 .93 & 630'ㅇ" & 21ㅇ'ㅇ' & 842 & 5.54 \\
\hline $\begin{array}{l}\text { Mclntosh, } 1878 \\
\text { Ammotrypanella cf. arctica }\end{array}$ & 2514 & 1 & 13.07.93 & 66-34'08" & $25 \div 13^{\prime} 68^{\prime \prime}$ & 465 & -0.34 \\
\hline $\begin{array}{l}\text { Mclntosh, } 1878 \\
\text { Ammotrypanella cf. arctica }\end{array}$ & 2697 & 9 & 02.09 .94 & $64 \div 10^{\prime} 20^{\prime \prime}$ & 27여'10" & 1042 & 4.20 \\
\hline $\begin{array}{l}\text { Mclntosh, } 1878 \\
\text { Ammotrypanella cf. arctica }\end{array}$ & 2698 & 1 & 02.09 .94 & 641ㅇ'50" & $2742^{\prime} 60^{\prime \prime}$ & 1038 & 4.20 \\
\hline $\begin{array}{l}\text { McIntosh, } 1878 \\
\text { Ammotrypanella cf. arctica }\end{array}$ & 2700 & 8 & 02.09 .94 & $64^{\circ} 05^{\prime} 60^{\prime \prime}$ & $27-50^{\prime} 00^{\prime \prime}$ & 1105 & 3.84 \\
\hline $\begin{array}{l}\text { McIntosh, } 1878 \\
\text { Ammotrypanella cf. arctica }\end{array}$ & 2701 & 37 & 02.09 .94 & $64^{\circ} 05^{\prime} 50^{\prime \prime}$ & 27우'ㅇ" & 1121 & 3.84 \\
\hline $\begin{array}{l}\text { McIntosh, } 1878 \\
\text { Ammotrypanella cf. arctica }\end{array}$ & 2704 & 16 & 02.09 .94 & $63 \div 50^{\prime} 50^{\prime \prime}$ & $27 \div 42^{\prime} 80^{\prime \prime}$ & 1295 & 3.80 \\
\hline $\begin{array}{l}\text { Mclntosh, } 1878 \\
\text { Ammotrypanella cf. arctica }\end{array}$ & 2706 & 6 & 03.09 .94 & $63 \div 55^{\prime} 80^{\prime \prime}$ & 2816'30" & 1406 & 3.71 \\
\hline $\begin{array}{l}\text { McIntosh, } 1878 \\
\text { Ammotrypanella cf. arctica }\end{array}$ & 2707 & 8 & 03.09 .94 & 635'ㅇ' & 28어'80" & 1407 & 3.71 \\
\hline $\begin{array}{l}\text { McIntosh, } 1878 \\
\text { Ammotrypanella cf. arctica }\end{array}$ & 2773 & 1 & 03.08 .95 & 69o14'89" & 14ㅇ16'52" & 1629 & -0.86 \\
\hline $\begin{array}{l}\text { McIntosh, } 1878 \\
\text { Ammotrypanella cf. arctica }\end{array}$ & 2777 & 1 & 03.08 .95 & 68으'80" & $14 \div 40^{\prime} 70^{\prime \prime}$ & 1556 & -0.78 \\
\hline $\begin{array}{l}\text { McIntosh, } 1878 \\
\text { Ammotrypanella cf. arctica }\end{array}$ & 2859 & 38 & 29.08 .95 & $61050 ' 22 "$ & $16052^{\prime} 86^{\prime \prime}$ & 2270 & 2.37 \\
\hline $\begin{array}{l}\text { McIntosh, } 1878 \\
\text { Ammotrypanella cf. arctica }\end{array}$ & 2860 & 63 & 30.08 .95 & 614' $43^{\prime \prime}$ & $16=57^{\prime} 48^{\prime \prime}$ & 2295 & 2.60 \\
\hline $\begin{array}{l}\text { McIntosh, } 1878 \\
\text { Ammotrypanella cf. arctica }\end{array}$ & 2863 & 30 & 30.08 .95 & 61ㅇ1'18" & $18^{\circ} 02^{\prime} 57^{\prime \prime}$ & 2400 & 2.07 \\
\hline $\begin{array}{l}\text { McIntosh, } 1878 \\
\text { Ammotrypanella cf. arctica }\end{array}$ & 2903 & 4 & 24.08 .96 & $65 \div 22^{\prime} 80^{\prime \prime}$ & $28020^{\prime} 63^{\prime \prime}$ & 1066 & 4.78 \\
\hline $\begin{array}{l}\text { McIntosh, } 1878 \\
\text { Ammotrypanella cf. arctica }\end{array}$ & 2908 & 8 & 25.08 .96 & 6515'67" & $28 \div 50 ' 27 "$ & 1301 & 3.96 \\
\hline $\begin{array}{l}\text { McIntosh, } 1878 \\
\text { Ammotrypanella cf. arctica }\end{array}$ & 2912 & 5 & 25.08 .96 & 6511'01" & 290'18" & 1456 & 3.90 \\
\hline $\begin{array}{l}\text { McIntosh, } 1878 \\
\text { Ammotrypanella cf. arctica }\end{array}$ & 3012 & 19 & 07.07.97 & $6122^{\prime} 20^{\prime \prime}$ & 15이'98" & 2133 & 3.29 \\
\hline $\begin{array}{l}\text { Mclntosh, } 1878 \\
\text { Ammotrypanella cf. arctica }\end{array}$ & 3072 & 1 & 12.07 .97 & $61953^{\prime} 65^{\prime \prime}$ & 150'15" & 2082 & 2.83 \\
\hline $\begin{array}{l}\text { McIntosh, } 1878 \\
\text { Ammotrypanella cf. arctica }\end{array}$ & 3073 & 9 & 12.07 .97 & 61이'ㄱ" & 150'ㄱ' & 2083 & 2.83 \\
\hline Mclntosh, 1878 & 3075 & 4 & 13.07 .97 & $62 \div 00 ' 19^{\prime \prime}$ & 1559'97" & 2192 & 3.07 \\
\hline
\end{tabular}




\begin{tabular}{|c|c|c|c|c|c|c|c|}
\hline Ammotrypanella cf. arctica & & & & & & & \\
\hline $\begin{array}{l}\text { Mclntosh, } 1878 \\
\text { Ammotrypanella cf. arctica }\end{array}$ & 3161 & 5 & 25.07 .00 & $62 \div 37^{\prime} 08^{\prime \prime}$ & $23 \div 21^{\prime} 79^{\prime \prime}$ & 1250 & 3.61 \\
\hline $\begin{array}{l}\text { Mclntosh, } 1878 \\
\text { Ammotrypanella cf. arctica }\end{array}$ & 3167 & 12 & 26.07 .00 & $60954 ' 88^{\prime \prime}$ & $22 \circ 47^{\prime} 26^{\prime \prime}$ & 1897 & 2.98 \\
\hline $\begin{array}{l}\text { McIntosh, } 1878 \\
\text { Ammotrypanella cf. arctica }\end{array}$ & 3173 & 1 & 28.07 .00 & $60 \div 05 ' 38 "$ & $20 \div 51^{\prime} 23^{\prime \prime}$ & 2709 & 2.68 \\
\hline $\begin{array}{l}\text { Mclntosh, } 1878 \\
\text { Ammotrypanella cf. arctica }\end{array}$ & 3204 & 75 & 08.07.01 & 6451'71" & 7ㅇ5'ㄷ'" & 2613 & -0.83 \\
\hline $\begin{array}{l}\text { McIntosh, } 1878 \\
\text { Ammotrypanella cf. arctica }\end{array}$ & 3208 & 75 & 09.07.01 & 6543'93" & 7응' $95^{\prime \prime}$ & 2002 & -0.87 \\
\hline $\begin{array}{l}\text { McIntosh, } 1878 \\
\text { Ammotrypanella cf. arctica }\end{array}$ & 3210 & 54 & 09.07.01 & 6613'66" & 6-51'77" & 2544 & -0.87 \\
\hline $\begin{array}{l}\text { McIntosh, } 1878 \\
\text { Ammotrypanella cf. arctica }\end{array}$ & 3214 & 695 & 10.07.01 & 6701'78" & 6011'83" & 3003 & -0.90 \\
\hline $\begin{array}{l}\text { McIntosh, } 1878 \\
\text { Ammotrypanella cf. arctica }\end{array}$ & 3216 & 56 & 11.07 .01 & 670''ㄷ" & 7은'12" & 2014 & -0.86 \\
\hline $\begin{array}{l}\text { McIntosh, } 1878 \\
\text { Ammotrypanella cf. arctica }\end{array}$ & 3219 & 35 & 11.07 .01 & 67ㅇ14'79" & 828'06" & 1642 & -0.82 \\
\hline $\begin{array}{l}\text { McIntosh, } 1878 \\
\text { Ammotrypanella cf. arctica }\end{array}$ & 3222 & 3 & 11.07 .01 & 67ㅇ5'77" & 80'94" & 1525 & -0.83 \\
\hline $\begin{array}{l}\text { Mclntosh, } 1878 \\
\text { Ammotrypanella cf. arctica }\end{array}$ & 3504 & 1 & 02.09 .02 & $622^{\circ} 01^{\prime} 46^{\prime \prime}$ & 1949'15" & 1733 & 3.09 \\
\hline $\begin{array}{l}\text { McIntosh, } 1878 \\
\text { Ammotrypanella cf. arctica }\end{array}$ & 3509 & 7 & 03.09 .02 & $62^{\circ} 02^{\prime} 40^{\prime \prime}$ & 19o38'71" & 1678 & 2.70 \\
\hline $\begin{array}{l}\text { McIntosh, } 1878 \\
\text { Ammotrypanella cf. arctica }\end{array}$ & 3514 & 1 & 04.09 .02 & $62 \div 25^{\prime} 59^{\prime \prime}$ & $19-46^{\prime} 15^{\prime \prime}$ & 1780 & 2.93 \\
\hline $\begin{array}{l}\text { Mclntosh, } 1878 \\
\text { Ammotrypanella cf. arctica }\end{array}$ & 3570 & 4 & 04.09 .03 & $63 \div 42^{\prime} 71^{\prime \prime}$ & 29o10'36" & 1819 & 3.24 \\
\hline $\begin{array}{l}\text { Mclntosh, } 1878 \\
\text { Ammotrypanella cf. arctica }\end{array}$ & 3573 & 2 & 05.09 .03 & $63 \div 22^{\prime} 49^{\prime \prime}$ & 295' $85 "$ & 2359 & 3.06 \\
\hline $\begin{array}{l}\text { McIntosh, } 1878 \\
\text { Ammotrypanella cf. arctica }\end{array}$ & 3621 & 4 & 14.07 .04 & 6629'39" & $9 \circ 44$ '80" & 1475 & -0.78 \\
\hline $\begin{array}{l}\text { McIntosh, } 1878 \\
\text { Ammotrypanella cf. arctica }\end{array}$ & 3624 & 19 & 14.07 .04 & $66059^{\prime} 48^{\prime \prime}$ & $8048^{\prime} 73^{\prime \prime}$ & 1628 & -0.82 \\
\hline $\begin{array}{l}\text { Mclntosh, } 1878 \\
\text { Ammotrypanella cf. arctica }\end{array}$ & 3628 & 15 & 15.07 .04 & 67ㅇ19'53" & 932'76" & 1609 & -0.81 \\
\hline $\begin{array}{l}\text { Mclntosh, } 1878 \\
\text { Ammotrypanella cf. arctica }\end{array}$ & 3632 & 100 & 16.07 .04 & 6800'92" & 9-14'78" & 1727 & -0.82 \\
\hline $\begin{array}{l}\text { McIntosh, } 1878 \\
\text { Ammotrypanella cf. arctica }\end{array}$ & 3633 & 191 & 17.07.04 & $68=25^{\prime} 12^{\prime \prime}$ & 85'72" & 1952 & -0.84 \\
\hline $\begin{array}{l}\text { McIntosh, } 1878 \\
\text { Ammotrypanella cf. arctica }\end{array}$ & 3636 & 7 & 17.07.04 & 6849'71" & 9o14'42" & 1844 & -0.81 \\
\hline $\begin{array}{l}\text { McIntosh, } 1878 \\
\text { Ammotrypanella cf. arctica }\end{array}$ & 3637 & 175 & 17.07.04 & 6826'92" & $10 \circ 08^{\prime} 75^{\prime \prime}$ & 2069 & -0.80 \\
\hline $\begin{array}{l}\text { McIntosh, } 1878 \\
\text { Ammotrypanella cf. arctica }\end{array}$ & 3638 & 1 & 18.07.04 & $68026^{\prime} 63^{\prime \prime}$ & 1010'58" & 2065 & -0.80 \\
\hline $\begin{array}{l}\text { McIntosh, } 1878 \\
\text { Ammotrypanella cf. arctica }\end{array}$ & 3640 & 120 & 18.07 .04 & 67ㅇ5'63" & $10 \circ 02^{\prime} 61^{\prime \prime}$ & 1915 & -0.82 \\
\hline $\begin{array}{l}\text { McIntosh, } 1878 \\
\text { Ammotrypanella cf. arctica }\end{array}$ & 3645 & 12 & 21.07 .04 & $67 \div 24^{\prime} 22^{\prime \prime}$ & $10 \cong 40^{\prime} 59^{\prime \prime}$ & 1703 & -0.81 \\
\hline $\begin{array}{l}\text { McIntosh, } 1878 \\
\text { Ammotrypanella cf. arctica }\end{array}$ & 3648 & 41 & 22.07 .04 & 685ㄱ'10" & $10032^{\prime} 80^{\prime \prime}$ & 2215 & -0.79 \\
\hline $\begin{array}{l}\text { McIntosh, } 1878 \\
\text { Ammotrypanella cf. arctica }\end{array}$ & 3649 & 9 & 22.07 .04 & $68 \div 56^{\prime} 45^{\prime \prime}$ & $10035^{\prime} 65^{\prime \prime}$ & 2214 & -0.79 \\
\hline $\begin{array}{l}\text { Mclntosh, } 1878 \\
\text { Ammotrypanella cf. arctica }\end{array}$ & 3652 & 146 & 22.07 .04 & $69904 ' 00^{\prime \prime}$ & $13 \div 33^{\prime} 85^{\prime \prime}$ & 1678 & -0.81 \\
\hline $\begin{array}{l}\text { McIntosh, } 1878 \\
\text { Ammotrypanella cf. arctica }\end{array}$ & 2027 & 1 & 23.07 .91 & 67ำ1'82" & $13 \div 20^{\prime} 58^{\prime \prime}$ & 1648 & -0.76 \\
\hline $\begin{array}{l}\text { Mclntosh, } 1878 \\
\text { Ammotrypanella cf. arctica }\end{array}$ & 2077 & 2 & 03.07 .92 & 67눙'51" & 17웅'38" & 1048 & -0.52 \\
\hline $\begin{array}{l}\text { McIntosh, } 1878 \\
\text { Ammotrypanella cf. arctica }\end{array}$ & 2257 & 28 & 05.09 .92 & 6314'61" & 2629'14" & 1209 & 4.09 \\
\hline Mclntosh, 1878 & 2310 & 116 & 11.09 .92 & 6334'09" & $22 \div 42^{\prime} 73^{\prime \prime}$ & 172 & 7.30 \\
\hline
\end{tabular}




\begin{tabular}{|c|c|c|c|c|c|c|c|}
\hline Ammotrypanella cf. arctica & & & & & & & \\
\hline $\begin{array}{l}\text { Mclntosh, } 1878 \\
\text { Ammotrypanella cf. arctica }\end{array}$ & 2403 & 12 & 01.07 .93 & $63 \div 02^{\prime} 90^{\prime \prime}$ & 21ㄴㅇ'60" & 838 & 5.49 \\
\hline $\begin{array}{l}\text { Mclntosh, } 1878 \\
\text { Ammotrypanella cf. arctica }\end{array}$ & 2404 & 1 & 01.07 .93 & $63 \div 02^{\prime} 30^{\prime \prime}$ & $21950 ' 80^{\prime \prime}$ & 802 & 5.49 \\
\hline $\begin{array}{l}\text { McIntosh, } 1878 \\
\text { Ammotrypanella cf. arctica }\end{array}$ & 2406 & 6 & 01.07 .93 & $62 \div 59 ' 20^{\prime \prime}$ & $21 \div 47^{\prime} 00^{\prime \prime}$ & 934 & 4.57 \\
\hline $\begin{array}{l}\text { Mclntosh, } 1878 \\
\text { Ammotrypanella cf. arctica }\end{array}$ & 2410 & 2 & 02.07 .93 & $62 \div 51^{\prime} 60^{\prime \prime}$ & 21여'10" & 1074 & 4.00 \\
\hline $\begin{array}{l}\text { McIntosh, } 1878 \\
\text { Ammotrypanella cf. arctica }\end{array}$ & 2415 & 7 & 02.07 .93 & 63000'18" & 21ㅇ0' $54 "$ & 819 & 5.36 \\
\hline $\begin{array}{l}\text { McIntosh, } 1878 \\
\text { Ammotrypanella cf. arctica }\end{array}$ & 2429 & 1 & 03.07 .93 & $63 \div 07^{\prime} 00^{\prime \prime}$ & $19-56^{\prime} 60^{\prime \prime}$ & 1072 & 4.80 \\
\hline $\begin{array}{l}\text { McIntosh, } 1878 \\
\text { Ammotrypanella cf. arctica }\end{array}$ & 2430 & 1 & 03.07 .93 & $63 \div 07^{\prime} 90^{\prime \prime}$ & $19-57^{\prime} 20^{\prime \prime}$ & 1016 & 4.80 \\
\hline $\begin{array}{l}\text { McIntosh, } 1878 \\
\text { Ammotrypanella cf. arctica }\end{array}$ & 2475 & 2 & 05.07 .93 & $63 \div 04 ' 20^{\prime \prime}$ & 21여'90" & 842 & 5.54 \\
\hline $\begin{array}{l}\text { McIntosh, } 1878 \\
\text { Ammotrypanella cf. arctica }\end{array}$ & 2514 & 1 & 13.07 .93 & $66034 ' 08 "$ & $25 \div 13^{\prime} 68^{\prime \prime}$ & 465 & -0.34 \\
\hline $\begin{array}{l}\text { McIntosh, } 1878 \\
\text { Ammotrypanella cf. arctica }\end{array}$ & 2697 & 9 & 02.09 .94 & 6410'20" & $2743^{\prime} 10^{\prime \prime}$ & 1042 & 4.20 \\
\hline $\begin{array}{l}\text { McIntosh, } 1878 \\
\text { Ammotrypanella cf. arctica }\end{array}$ & 2698 & 1 & 02.09 .94 & $64 \div 10^{\prime} 50^{\prime \prime}$ & $27 \div 42^{\prime} 60^{\prime \prime}$ & 1038 & 4.20 \\
\hline $\begin{array}{l}\text { McIntosh, } 1878 \\
\text { Ammotrypanella cf. arctica }\end{array}$ & 2700 & 8 & 02.09 .94 & $64^{\circ} 05^{\prime} 60^{\prime \prime}$ & 27응'00" & 1105 & 3.84 \\
\hline $\begin{array}{l}\text { Mclntosh, } 1878 \\
\text { Ammotrypanella cf. arctica }\end{array}$ & 2701 & 37 & 02.09.94 & $64 \div 05 ' 50 "$ & 27ㅇำ'70" & 1121 & 3.84 \\
\hline $\begin{array}{l}\text { Mclntosh, } 1878 \\
\text { Ammotrypanella cf. arctica }\end{array}$ & 2704 & 16 & 02.09 .94 & $63 \div 50 ' 50 "$ & 27은' $80^{\prime \prime}$ & 1295 & 3.80 \\
\hline $\begin{array}{l}\text { Mclntosh, } 1878 \\
\text { Ammotrypanella cf. arctica }\end{array}$ & 2706 & 6 & 03.09.94 & $63 \div 55^{\prime} 80^{\prime \prime}$ & 2816'30" & 1406 & 3.71 \\
\hline $\begin{array}{l}\text { McIntosh, } 1878 \\
\text { Ammotrypanella cf. arctica }\end{array}$ & 2707 & 8 & 03.09.94 & $63 \div 55^{\prime} 30^{\prime \prime}$ & 2816'80" & 1407 & 3.71 \\
\hline $\begin{array}{l}\text { McIntosh, } 1878 \\
\text { Ammotrypanella cf. arctica }\end{array}$ & 2773 & 1 & 03.08 .95 & 69o14'89" & $14016^{\prime} 52^{\prime \prime}$ & 1629 & -0.86 \\
\hline $\begin{array}{l}\text { McIntosh, } 1878 \\
\text { Ammotrypanella cf. arctica }\end{array}$ & 2777 & 1 & 03.08 .95 & $68 \div 36^{\prime} 80^{\prime \prime}$ & $14 \div 40^{\prime} 70^{\prime \prime}$ & 1556 & -0.78 \\
\hline $\begin{array}{l}\text { Mclntosh, } 1878 \\
\text { Ammotrypanella cf. arctica }\end{array}$ & 2859 & 38 & 29.08 .95 & $61950 ' 22 "$ & $16052^{\prime} 86^{\prime \prime}$ & 2270 & 2.37 \\
\hline $\begin{array}{l}\text { McIntosh, } 1878 \\
\text { Ammotrypanella cf. arctica }\end{array}$ & 2860 & 63 & 30.08 .95 & 61녀'43" & $16057^{\prime} 48^{\prime \prime}$ & 2295 & 2.60 \\
\hline $\begin{array}{l}\text { McIntosh, } 1878 \\
\text { Ammotrypanella cf. arctica }\end{array}$ & 2863 & 30 & 30.08 .95 & 61이'18" & $18902^{\prime} 57^{\prime \prime}$ & 2400 & 2.07 \\
\hline $\begin{array}{l}\text { McIntosh, } 1878 \\
\text { Ammotrypanella cf. arctica }\end{array}$ & 2903 & 4 & 24.08 .96 & $65 \div 22^{\prime} 80^{\prime \prime}$ & $28 \div 20^{\prime} 63^{\prime \prime}$ & 1066 & 4.78 \\
\hline $\begin{array}{l}\text { McIntosh, } 1878 \\
\text { Ammotrypanella cf. arctica }\end{array}$ & 2908 & 8 & 25.08 .96 & 6515'67" & $28 \div 50 ' 27 "$ & 1301 & 3.96 \\
\hline $\begin{array}{l}\text { Mclntosh, } 1878 \\
\text { Ammotrypanella cf. arctica }\end{array}$ & 2912 & 5 & 25.08 .96 & 6511'01" & 2904'18" & 1456 & 3.90 \\
\hline $\begin{array}{l}\text { McIntosh, } 1878 \\
\text { Ammotrypanella cf. arctica }\end{array}$ & 3012 & 19 & 07.07.97 & $6122^{\prime} 20^{\prime \prime}$ & 15이' $98^{\prime \prime}$ & 2133 & 3.29 \\
\hline $\begin{array}{l}\text { McIntosh, } 1878 \\
\text { Ammotrypanella cf. arctica }\end{array}$ & 3072 & 1 & 12.07 .97 & $61053^{\prime} 65^{\prime \prime}$ & $15 \div 08^{\prime} 15^{\prime \prime}$ & 2082 & 2.83 \\
\hline $\begin{array}{l}\text { McIntosh, } 1878 \\
\text { Ammotrypanella cf. arctica }\end{array}$ & 3073 & 9 & 12.07 .97 & 61ㅇ5'78" & 150'ㄱ' & 2083 & 2.83 \\
\hline $\begin{array}{l}\text { Mclntosh, } 1878 \\
\text { Ammotrypanella cf. arctica }\end{array}$ & 3075 & 4 & 13.07.97 & $622^{\circ} 00^{\prime} 19^{\prime \prime}$ & $15 \div 59^{\prime} 97^{\prime \prime}$ & 2192 & 3.07 \\
\hline $\begin{array}{l}\text { McIntosh, } 1878 \\
\text { Ammotrypanella cf. arctica }\end{array}$ & 3161 & 5 & 25.07 .00 & $62 \div 37^{\prime} 08^{\prime \prime}$ & 2321'79" & 1250 & 3.61 \\
\hline $\begin{array}{l}\text { Mclntosh, } 1878 \\
\text { Ammotrypanella cf. arctica }\end{array}$ & 3167 & 12 & 26.07 .00 & $60 \div 54 ' 88^{\prime \prime}$ & $22 \div 47^{\prime} 26^{\prime \prime}$ & 1897 & 2.98 \\
\hline $\begin{array}{l}\text { McIntosh, } 1878 \\
\text { Ammotrypanella cf. arctica }\end{array}$ & 3173 & 1 & 28.07 .00 & $60 \circ 05^{\prime} 38^{\prime \prime}$ & $20-51^{\prime} 23^{\prime \prime}$ & 2709 & 2.68 \\
\hline Mclntosh, 1878 & 3204 & 75 & 08.07.01 & 6451'71" & 7ㅇ5'ㄷ' & 2613 & -0.83 \\
\hline
\end{tabular}




\begin{tabular}{|c|c|c|c|c|c|c|c|}
\hline Ammotrypanella cf. arctica & & & & & & & \\
\hline $\begin{array}{l}\text { Mclntosh, } 1878 \\
\text { Ammotrypanella cf. arctica }\end{array}$ & 3208 & 75 & 09.07.01 & $65 \div 43^{\prime} 93^{\prime \prime}$ & 7o0'ㄷ' & 2002 & -0.87 \\
\hline $\begin{array}{l}\text { Mclntosh, } 1878 \\
\text { Ammotrypanella cf. arctica }\end{array}$ & 3210 & 54 & 09.07.01 & $66013^{\prime} 66^{\prime \prime}$ & 651'77" & 2544 & -0.87 \\
\hline $\begin{array}{l}\text { McIntosh, } 1878 \\
\text { Ammotrypanella cf. arctica }\end{array}$ & 3214 & 695 & 10.07.01 & 67ㅇ0'ㄱ' & 6011'83" & 3003 & -0.90 \\
\hline $\begin{array}{l}\text { Mclntosh, } 1878 \\
\text { Ammotrypanella cf. arctica }\end{array}$ & 3216 & 56 & 11.07 .01 & $67^{\circ} 05^{\prime} 86^{\prime \prime}$ & 7은'12" & 2014 & -0.86 \\
\hline $\begin{array}{l}\text { McIntosh, } 1878 \\
\text { Ammotrypanella cf. arctica }\end{array}$ & 3219 & 35 & 11.07 .01 & 67ำ14'79" & 828'06" & 1642 & -0.82 \\
\hline $\begin{array}{l}\text { McIntosh, } 1878 \\
\text { Ammotrypanella cf. arctica }\end{array}$ & 3222 & 3 & 11.07 .01 & $67053^{\prime} 77^{\prime \prime}$ & 80'94" & 1525 & -0.83 \\
\hline $\begin{array}{l}\text { McIntosh, } 1878 \\
\text { Ammotrypanella cf. arctica }\end{array}$ & 3504 & 1 & 02.09 .02 & $62 \circ 01^{\prime} 46^{\prime \prime}$ & $19-49^{\prime} 15^{\prime \prime}$ & 1733 & 3.09 \\
\hline $\begin{array}{l}\text { Mclntosh, } 1878 \\
\text { Ammotrypanella cf. arctica }\end{array}$ & 3509 & 7 & 03.09 .02 & $62^{\circ} 02^{\prime} 40^{\prime \prime}$ & 193' $71^{\prime \prime}$ & 1678 & 2.70 \\
\hline $\begin{array}{l}\text { Mclntosh, } 1878 \\
\text { Ammotrypanella cf. arctica }\end{array}$ & 3514 & 1 & 04.09 .02 & $62 \div 25^{\prime} 59^{\prime \prime}$ & $19 \circ 46^{\prime} 15^{\prime \prime}$ & 1780 & 2.93 \\
\hline $\begin{array}{l}\text { McIntosh, } 1878 \\
\text { Ammotrypanella cf. arctica }\end{array}$ & 3570 & 4 & 04.09 .03 & $63 \div 42^{\prime} 71^{\prime \prime}$ & 2910'36" & 1819 & 3.24 \\
\hline $\begin{array}{l}\text { Mclntosh, } 1878 \\
\text { Ammotrypanella cf. arctica }\end{array}$ & 3573 & 2 & 05.09 .03 & $6322^{\prime} 49^{\prime \prime}$ & $29 \circ 54$ '85" & 2359 & 3.06 \\
\hline $\begin{array}{l}\text { Mclntosh, } 1878 \\
\text { Ammotrypanella cf. arctica }\end{array}$ & 3621 & 4 & 14.07 .04 & 6629'39" & $9 \circ 44^{\prime} 80^{\prime \prime}$ & 1475 & -0.78 \\
\hline $\begin{array}{l}\text { Mclntosh, } 1878 \\
\text { Ammotrypanella cf. arctica }\end{array}$ & 3624 & 19 & 14.07.04 & $66059^{\prime} 48^{\prime \prime}$ & $8 \div 48^{\prime} 73^{\prime \prime}$ & 1628 & -0.82 \\
\hline $\begin{array}{l}\text { McIntosh, } 1878 \\
\text { Ammotrypanella cf. arctica }\end{array}$ & 3628 & 15 & 15.07.04 & 67ำ19'53" & 932'76" & 1609 & -0.81 \\
\hline $\begin{array}{l}\text { Mclntosh, } 1878 \\
\text { Ammotrypanella cf. arctica }\end{array}$ & 3632 & 100 & 16.07.04 & 6800'92" & 914'78" & 1727 & -0.82 \\
\hline $\begin{array}{l}\text { McIntosh, } 1878 \\
\text { Ammotrypanella cf. arctica }\end{array}$ & 3633 & 191 & 17.07.04 & $68 \div 25^{\prime} 12^{\prime \prime}$ & 85'72" & 1952 & -0.84 \\
\hline $\begin{array}{l}\text { McIntosh, } 1878 \\
\text { Ammotrypanella cf. arctica }\end{array}$ & 3636 & 7 & 17.07.04 & 6849'71" & 914'42" & 1844 & -0.81 \\
\hline $\begin{array}{l}\text { McIntosh, } 1878 \\
\text { Ammotrypanella cf. arctica }\end{array}$ & 3637 & 175 & 17.07 .04 & 68으' & $10 \div 08 ' 75^{\prime \prime}$ & 2069 & -0.80 \\
\hline $\begin{array}{l}\text { Mclntosh, } 1878 \\
\text { Ammotrypanella cf. arctica }\end{array}$ & 3638 & 1 & 18.07.04 & $68 \div 26^{\prime} 63^{\prime \prime}$ & $10-10^{\prime} 58^{\prime \prime}$ & 2065 & -0.80 \\
\hline $\begin{array}{l}\text { McIntosh, } 1878 \\
\text { Ammotrypanella cf. arctica }\end{array}$ & 3640 & 120 & 18.07.04 & 67ㅇ5'63" & $10 \div 02 ' 61^{\prime \prime}$ & 1915 & -0.82 \\
\hline $\begin{array}{l}\text { McIntosh, } 1878 \\
\text { Ammotrypanella cf. arctica }\end{array}$ & 3645 & 12 & 21.07 .04 & $67 \div 24^{\prime} 22^{\prime \prime}$ & $10 \div 40 ' 59 "$ & 1703 & -0.81 \\
\hline $\begin{array}{l}\text { McIntosh, } 1878 \\
\text { Ammotrypanella cf. arctica }\end{array}$ & 3648 & 41 & 22.07 .04 & $68 \div 57^{\prime} 10^{\prime \prime}$ & $10 \div 32 ' 80^{\prime \prime}$ & 2215 & -0.79 \\
\hline $\begin{array}{l}\text { McIntosh, } 1878 \\
\text { Ammotrypanella cf. arctica }\end{array}$ & 3649 & 9 & 22.07 .04 & $68956^{\prime} 45^{\prime \prime}$ & $10 \div 35^{\prime} 65^{\prime \prime}$ & 2214 & -0.79 \\
\hline $\begin{array}{l}\text { McIntosh, } 1878 \\
\text { Ammotrypanella cf. arctica }\end{array}$ & 3652 & 146 & 22.07 .04 & $699^{\circ} 04^{\prime} 00^{\prime \prime}$ & $13 \div 33^{\prime} 85^{\prime \prime}$ & 1678 & -0.81 \\
\hline $\begin{array}{l}\text { Mclntosh, } 1878 \\
\text { Ammotrypanella cf. arctica }\end{array}$ & 2027 & 1 & 23.07.91 & 67ำ11'82" & $13 \div 20^{\prime} 58^{\prime \prime}$ & 1648 & -0.76 \\
\hline $\begin{array}{l}\text { Mclntosh, } 1878 \\
\text { Ammotrypanella cf. arctica }\end{array}$ & 2077 & 2 & 03.07.92 & $6740^{\prime} 51^{\prime \prime}$ & $17 \div 10^{\prime} 38^{\prime \prime}$ & 1048 & -0.52 \\
\hline $\begin{array}{l}\text { McIntosh, } 1878 \\
\text { Ammotrypanella cf. arctica }\end{array}$ & 2257 & 28 & 05.09.92 & 6314'61" & 2629'14" & 1209 & 4.09 \\
\hline $\begin{array}{l}\text { McIntosh, } 1878 \\
\text { Ammotrypanella cf. arctica }\end{array}$ & 2310 & 116 & 11.09 .92 & 6334'09" & $22 \circ 42^{\prime} 73^{\prime \prime}$ & 172 & 7.30 \\
\hline $\begin{array}{l}\text { McIntosh, } 1878 \\
\text { Ammotrypanella cf. arctica }\end{array}$ & 2403 & 12 & 01.07 .93 & $63 \div 02^{\prime} 90^{\prime \prime}$ & $21 \div 49^{\prime} 60^{\prime \prime}$ & 838 & 5.49 \\
\hline $\begin{array}{l}\text { Mclntosh, } 1878 \\
\text { Ammotrypanella cf. arctica }\end{array}$ & 2404 & 1 & 01.07 .93 & 630'ㅇ' & 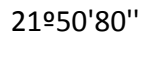 & 802 & 5.49 \\
\hline $\begin{array}{l}\text { McIntosh, } 1878 \\
\text { Ammotrypanella cf. arctica }\end{array}$ & 2406 & 6 & 01.07 .93 & $62 \div 59 ' 20^{\prime \prime}$ & $21477^{\prime} 00^{\prime \prime}$ & 934 & 4.57 \\
\hline Mclntosh, 1878 & 2410 & 2 & 02.07 .93 & $62 \div 51^{\prime} 60^{\prime \prime}$ & 21여'10" & 1074 & 4.00 \\
\hline
\end{tabular}




\begin{tabular}{|c|c|c|c|c|c|c|c|}
\hline Ammotrypanella cf. arctica & & & & & & & \\
\hline $\begin{array}{l}\text { Mclntosh, } 1878 \\
\text { Ammotrypanella cf. arctica }\end{array}$ & 2415 & 7 & 02.07 .93 & $63 \div 00 ' 18^{\prime \prime}$ & 21ㅇo' $54^{\prime \prime}$ & 819 & 5.36 \\
\hline $\begin{array}{l}\text { Mclntosh, } 1878 \\
\text { Ammotrypanella cf. arctica }\end{array}$ & 2429 & 1 & 03.07 .93 & $63 \div 07^{\prime} 00^{\prime \prime}$ & $199566^{\prime} 60^{\prime \prime}$ & 1072 & 4.80 \\
\hline $\begin{array}{l}\text { McIntosh, } 1878 \\
\text { Ammotrypanella cf. arctica }\end{array}$ & 2430 & 1 & 03.07.93 & 630' $90^{\prime \prime}$ & $19 \div 57^{\prime} 20^{\prime \prime}$ & 1016 & 4.80 \\
\hline $\begin{array}{l}\text { Mclntosh, } 1878 \\
\text { Ammotrypanella cf. arctica }\end{array}$ & 2475 & 2 & 05.07 .93 & 630' $20^{\prime \prime}$ & 21ㅇ' $90^{\prime \prime}$ & 842 & 5.54 \\
\hline $\begin{array}{l}\text { McIntosh, } 1878 \\
\text { Ammotrypanella cf. arctica }\end{array}$ & 2514 & 1 & 13.07 .93 & $66034 ' 08^{\prime \prime}$ & 2513'68" & 465 & -0.34 \\
\hline $\begin{array}{l}\text { McIntosh, } 1878 \\
\text { Ammotrypanella cf. arctica }\end{array}$ & 2697 & 9 & 02.09 .94 & 6410'20" & $27 \div 43^{\prime} 10^{\prime \prime}$ & 1042 & 4.20 \\
\hline $\begin{array}{l}\text { McIntosh, } 1878 \\
\text { Ammotrypanella cf. arctica }\end{array}$ & 2698 & 1 & 02.09 .94 & $64 \div 10^{\prime} 50^{\prime \prime}$ & $27 \div 42^{\prime} 60^{\prime \prime}$ & 1038 & 4.20 \\
\hline $\begin{array}{l}\text { McIntosh, } 1878 \\
\text { Ammotrypanella cf. arctica }\end{array}$ & 2700 & 8 & 02.09 .94 & $64^{\circ} 05^{\prime} 60^{\prime \prime}$ & $27 \div 50^{\prime} 00^{\prime \prime}$ & 1105 & 3.84 \\
\hline $\begin{array}{l}\text { McIntosh, } 1878 \\
\text { Ammotrypanella cf. arctica }\end{array}$ & 2701 & 37 & 02.09 .94 & $64 \div 05^{\prime} 50^{\prime \prime}$ & 27누'ㅇ' & 1121 & 3.84 \\
\hline $\begin{array}{l}\text { McIntosh, } 1878 \\
\text { Ammotrypanella cf. arctica }\end{array}$ & 2704 & 16 & 02.09 .94 & $63 \div 50^{\prime} 50^{\prime \prime}$ & $27 ㅇ 2^{\prime} 80^{\prime \prime}$ & 1295 & 3.80 \\
\hline $\begin{array}{l}\text { McIntosh, } 1878 \\
\text { Ammotrypanella cf. arctica }\end{array}$ & 2706 & 6 & 03.09 .94 & $63 \div 55^{\prime} 80^{\prime \prime}$ & 28어'30" & 1406 & 3.71 \\
\hline $\begin{array}{l}\text { McIntosh, } 1878 \\
\text { Ammotrypanella cf. arctica }\end{array}$ & 2707 & 8 & 03.09 .94 & 635'ㅇ' & 28이'ㅇ" & 1407 & 3.71 \\
\hline $\begin{array}{l}\text { McIntosh, } 1878 \\
\text { Ammotrypanella cf. arctica }\end{array}$ & 2773 & 1 & 03.08 .95 & 6914'89" & $14^{\circ} 16^{\prime} 52^{\prime \prime}$ & 1629 & -0.86 \\
\hline $\begin{array}{l}\text { Mclntosh, } 1878 \\
\text { Ammotrypanella cf. arctica }\end{array}$ & 2777 & 1 & 03.08 .95 & $68 \div 36 ' 80^{\prime \prime}$ & $14 \div 40^{\prime} 70^{\prime \prime}$ & 1556 & -0.78 \\
\hline $\begin{array}{l}\text { Mclntosh, } 1878 \\
\text { Ammotrypanella cf. arctica }\end{array}$ & 2859 & 38 & 29.08 .95 & 61응'22" & $16952^{\prime} 86^{\prime \prime}$ & 2270 & 2.37 \\
\hline $\begin{array}{l}\text { McIntosh, } 1878 \\
\text { Ammotrypanella cf. arctica }\end{array}$ & 2860 & 63 & 30.08 .95 & $61043^{\prime} 43^{\prime \prime}$ & $16957^{\prime} 48^{\prime \prime}$ & 2295 & 2.60 \\
\hline $\begin{array}{l}\text { McIntosh, } 1878 \\
\text { Ammotrypanella cf. arctica }\end{array}$ & 2863 & 30 & 30.08 .95 & 61ำ10'18" & $18^{\circ} 02^{\prime} 57^{\prime \prime}$ & 2400 & 2.07 \\
\hline $\begin{array}{l}\text { McIntosh, } 1878 \\
\text { Ammotrypanella cf. arctica }\end{array}$ & 2903 & 4 & 24.08 .96 & $65 \div 22^{\prime} 80^{\prime \prime}$ & $28020^{\prime} 63^{\prime \prime}$ & 1066 & 4.78 \\
\hline $\begin{array}{l}\text { Mclntosh, } 1878 \\
\text { Ammotrypanella cf. arctica }\end{array}$ & 2908 & 8 & 25.08 .96 & 6515'67" & $28 \div 50 ' 27^{\prime \prime}$ & 1301 & 3.96 \\
\hline $\begin{array}{l}\text { McIntosh, } 1878 \\
\text { Ammotrypanella cf. arctica }\end{array}$ & 2912 & 5 & 25.08 .96 & 6511'01" & 29o04'18" & 1456 & 3.90 \\
\hline $\begin{array}{l}\text { McIntosh, } 1878 \\
\text { Ammotrypanella cf. arctica }\end{array}$ & 3012 & 19 & 07.07.97 & $6122^{\prime} 20^{\prime \prime}$ & 15이' $98^{\prime \prime}$ & 2133 & 3.29 \\
\hline $\begin{array}{l}\text { McIntosh, } 1878 \\
\text { Ammotrypanella cf. arctica }\end{array}$ & 3072 & 1 & 12.07 .97 & 61이'65" & 150'15" & 2082 & 2.83 \\
\hline $\begin{array}{l}\text { McIntosh, } 1878 \\
\text { Ammotrypanella cf. arctica }\end{array}$ & 3073 & 9 & 12.07 .97 & 61이'ㅇ" & 150'ㄱ' & 2083 & 2.83 \\
\hline $\begin{array}{l}\text { Mclntosh, } 1878 \\
\text { Ammotrypanella cf. arctica }\end{array}$ & 3075 & 4 & 13.07 .97 & $62^{\circ} 00^{\prime} 19^{\prime \prime}$ & 1559'97" & 2192 & 3.07 \\
\hline $\begin{array}{l}\text { McIntosh, } 1878 \\
\text { Ammotrypanella cf. arctica }\end{array}$ & 3161 & 5 & 25.07 .00 & $62 \div 37^{\prime} 08^{\prime \prime}$ & 2321'79" & 1250 & 3.61 \\
\hline $\begin{array}{l}\text { McIntosh, } 1878 \\
\text { Ammotrypanella cf. arctica }\end{array}$ & 3167 & 12 & 26.07 .00 & $60 \div 54 ' 88^{\prime \prime}$ & $22 \circ 47^{\prime} 26^{\prime \prime}$ & 1897 & 2.98 \\
\hline $\begin{array}{l}\text { McIntosh, } 1878 \\
\text { Ammotrypanella cf. arctica }\end{array}$ & 3173 & 1 & 28.07 .00 & 6005'38" & 2051'23" & 2709 & 2.68 \\
\hline $\begin{array}{l}\text { Mclntosh, } 1878 \\
\text { Ammotrypanella cf. arctica }\end{array}$ & 3204 & 75 & 08.07.01 & 645'ㄱ' & 7ㅇ5'56" & 2613 & -0.83 \\
\hline $\begin{array}{l}\text { McIntosh, } 1878 \\
\text { Ammotrypanella cf. arctica }\end{array}$ & 3208 & 75 & 09.07.01 & 6543'93" & 7으'ㄷ' & 2002 & -0.87 \\
\hline $\begin{array}{l}\text { Mclntosh, } 1878 \\
\text { Ammotrypanella cf. arctica }\end{array}$ & 3210 & 54 & 09.07.01 & $66013^{\prime} 66^{\prime \prime}$ & 6-51'77" & 2544 & -0.87 \\
\hline $\begin{array}{l}\text { McIntosh, } 1878 \\
\text { Ammotrypanella cf. arctica }\end{array}$ & 3214 & 695 & 10.07.01 & 67ㅇ0'ㄱ" & 6o11'83" & 3003 & -0.90 \\
\hline Mclntosh, 1878 & 3216 & 56 & 11.07 .01 & 67ㅇ5'86" & 7윽'12" & 2014 & -0.86 \\
\hline
\end{tabular}




\begin{tabular}{|c|c|c|c|c|c|c|c|}
\hline Ammotrypanella cf. arctica & & & & & & & \\
\hline $\begin{array}{l}\text { Mclntosh, } 1878 \\
\text { Ammotrypanella cf. arctica }\end{array}$ & 3219 & 35 & 11.07.01 & 67ำ14'79" & $8 \div 28 ' 06^{\prime \prime}$ & 1642 & -0.82 \\
\hline $\begin{array}{l}\text { Mclntosh, } 1878 \\
\text { Ammotrypanella cf. arctica }\end{array}$ & 3222 & 3 & 11.07 .01 & 67ㅇ5'ㄱ' & $8 \div 05 ' 94 "$ & 1525 & -0.83 \\
\hline $\begin{array}{l}\text { McIntosh, } 1878 \\
\text { Ammotrypanella cf. arctica }\end{array}$ & 3504 & 1 & 02.09 .02 & $622^{\circ} 01^{\prime} 46^{\prime \prime}$ & 1949'15" & 1733 & 3.09 \\
\hline $\begin{array}{l}\text { Mclntosh, } 1878 \\
\text { Ammotrypanella cf. arctica }\end{array}$ & 3509 & 7 & 03.09 .02 & $62^{\circ} 02^{\prime} 40^{\prime \prime}$ & 19o38'71" & 1678 & 2.70 \\
\hline $\begin{array}{l}\text { McIntosh, } 1878 \\
\text { Ammotrypanella cf. arctica }\end{array}$ & 3514 & 1 & 04.09 .02 & $62 \div 25^{\prime} 59^{\prime \prime}$ & $19046^{\prime} 15^{\prime \prime}$ & 1780 & 2.93 \\
\hline $\begin{array}{l}\text { McIntosh, } 1878 \\
\text { Ammotrypanella cf. arctica }\end{array}$ & 3570 & 4 & 04.09 .03 & $63 \div 42^{\prime} 71^{\prime \prime}$ & 29o10'36" & 1819 & 3.24 \\
\hline $\begin{array}{l}\text { McIntosh, } 1878 \\
\text { Ammotrypanella cf. arctica }\end{array}$ & 3573 & 2 & 05.09 .03 & $63 \div 22^{\prime} 49^{\prime \prime}$ & $29 \div 54 ' 85^{\prime \prime}$ & 2359 & 3.06 \\
\hline $\begin{array}{l}\text { McIntosh, } 1878 \\
\text { Ammotrypanella cf. arctica }\end{array}$ & 3621 & 4 & 14.07 .04 & 66029'39" & $9 \div 44 ' 80 "$ & 1475 & -0.78 \\
\hline $\begin{array}{l}\text { McIntosh, } 1878 \\
\text { Ammotrypanella cf. arctica }\end{array}$ & 3624 & 19 & 14.07 .04 & $66 \div 59^{\prime} 48^{\prime \prime}$ & 848'73" & 1628 & -0.82 \\
\hline $\begin{array}{l}\text { McIntosh, } 1878 \\
\text { Ammotrypanella cf. arctica }\end{array}$ & 3628 & 15 & 15.07 .04 & 67ำ19'53" & 932'76" & 1609 & -0.81 \\
\hline $\begin{array}{l}\text { Mclntosh, } 1878 \\
\text { Ammotrypanella cf. arctica }\end{array}$ & 3632 & 100 & 16.07.04 & 6800'92" & 914'78" & 1727 & -0.82 \\
\hline $\begin{array}{l}\text { McIntosh, } 1878 \\
\text { Ammotrypanella cf. arctica }\end{array}$ & 3633 & 191 & 17.07.04 & $68025^{\prime} 12^{\prime \prime}$ & 85'72" & 1952 & -0.84 \\
\hline $\begin{array}{l}\text { McIntosh, } 1878 \\
\text { Ammotrypanella cf. arctica }\end{array}$ & 3636 & 7 & 17.07.04 & 6849'71" & 9-14'42" & 1844 & -0.81 \\
\hline $\begin{array}{l}\text { McIntosh, } 1878 \\
\text { Ammotrypanella cf. arctica }\end{array}$ & 3637 & 175 & 17.07.04 & $68 \div 26^{\prime} 92^{\prime \prime}$ & $10908^{\prime} 75^{\prime \prime}$ & 2069 & -0.80 \\
\hline $\begin{array}{l}\text { Mclntosh, } 1878 \\
\text { Ammotrypanella cf. arctica }\end{array}$ & 3638 & 1 & 18.07.04 & $68 \div 26^{\prime} 63^{\prime \prime}$ & 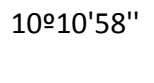 & 2065 & -0.80 \\
\hline $\begin{array}{l}\text { McIntosh, } 1878 \\
\text { Ammotrypanella cf. arctica }\end{array}$ & 3640 & 120 & 18.07.04 & 67ㅇ5'63" & $10 \circ 02^{\prime} 61^{\prime \prime}$ & 1915 & -0.82 \\
\hline $\begin{array}{l}\text { McIntosh, } 1878 \\
\text { Ammotrypanella cf. arctica }\end{array}$ & 3645 & 12 & 21.07 .04 & $67024^{\prime} 22^{\prime \prime}$ & $10 \circ 40^{\prime} 59^{\prime \prime}$ & 1703 & -0.81 \\
\hline $\begin{array}{l}\text { McIntosh, } 1878 \\
\text { Ammotrypanella cf. arctica }\end{array}$ & 3648 & 41 & 22.07 .04 & 68이'10" & $10032^{\prime} 80^{\prime \prime}$ & 2215 & -0.79 \\
\hline $\begin{array}{l}\text { Mclntosh, } 1878 \\
\text { Ammotrypanella cf. arctica }\end{array}$ & 3649 & 9 & 22.07 .04 & $68 \div 56^{\prime} 45^{\prime \prime}$ & $10 \circ 35^{\prime} 65^{\prime \prime}$ & 2214 & -0.79 \\
\hline $\begin{array}{l}\text { McIntosh, } 1878 \\
\text { Ammotrypanella cf. arctica }\end{array}$ & 3652 & 146 & 22.07 .04 & 690'00" & 13ㅇ'ㅇ' & 1678 & -0.81 \\
\hline $\begin{array}{l}\text { Mclntosh, } 1878 \\
\text { Ammotrypanella cf. arctica }\end{array}$ & 2027 & 1 & 23.07.91 & 67ำ11'82" & $13 \div 20^{\prime} 58^{\prime \prime}$ & 1648 & -0.76 \\
\hline $\begin{array}{l}\text { McIntosh, } 1878 \\
\text { Ammotrypanella cf. arctica }\end{array}$ & 2077 & 2 & 03.07 .92 & 67누'51" & 17웅'38" & 1048 & -0.52 \\
\hline $\begin{array}{l}\text { McIntosh, } 1878 \\
\text { Ammotrypanella cf. arctica }\end{array}$ & 2257 & 28 & 05.09.92 & 6314'61" & 26ㅇ'ㄹ' & 1209 & 4.09 \\
\hline $\begin{array}{l}\text { McIntosh, } 1878 \\
\text { Ammotrypanella cf. arctica }\end{array}$ & 2310 & 116 & 11.09 .92 & 6334'09" & $22 \div 42^{\prime} 73^{\prime \prime}$ & 172 & 7.30 \\
\hline $\begin{array}{l}\text { McIntosh, } 1878 \\
\text { Ammotrypanella cf. arctica }\end{array}$ & 2403 & 12 & 01.07 .93 & $63 \div 02^{\prime} 90^{\prime \prime}$ & 21ㄴㅇ'60" & 838 & 5.49 \\
\hline $\begin{array}{l}\text { McIntosh, } 1878 \\
\text { Ammotrypanella cf. arctica }\end{array}$ & 2404 & 1 & 01.07 .93 & 630'ㅇ' & 21응' $80^{\prime \prime}$ & 802 & 5.49 \\
\hline $\begin{array}{l}\text { McIntosh, } 1878 \\
\text { Ammotrypanella cf. arctica }\end{array}$ & 2406 & 6 & 01.07.93 & $62 \div 59 ' 20^{\prime \prime}$ & $2147^{\prime} 00^{\prime \prime}$ & 934 & 4.57 \\
\hline $\begin{array}{l}\text { McIntosh, } 1878 \\
\text { Ammotrypanella cf. arctica }\end{array}$ & 2410 & 2 & 02.07 .93 & $62 \div 51^{\prime} 60^{\prime \prime}$ & 21ㄴㄴ'10" & 1074 & 4.00 \\
\hline $\begin{array}{l}\text { McIntosh, } 1878 \\
\text { Ammotrypanella cf. arctica }\end{array}$ & 2415 & 7 & 02.07 .93 & 63000'18" & 21ㅇo'54" & 819 & 5.36 \\
\hline $\begin{array}{l}\text { Mclntosh, } 1878 \\
\text { Ammotrypanella cf. arctica }\end{array}$ & 2429 & 1 & 03.07 .93 & $63 \div 07^{\prime} 00^{\prime \prime}$ & $199566^{\prime} 60^{\prime \prime}$ & 1072 & 4.80 \\
\hline $\begin{array}{l}\text { McIntosh, } 1878 \\
\text { Ammotrypanella cf. arctica }\end{array}$ & 2430 & 1 & 03.07 .93 & 630' & $19-57^{\prime} 20^{\prime \prime}$ & 1016 & 4.80 \\
\hline Mclntosh, 1878 & 2475 & 2 & 05.07 .93 & $63 \div 04^{\prime} 20^{\prime \prime}$ & 213' $90^{\prime \prime}$ & 842 & 5.54 \\
\hline
\end{tabular}




\begin{tabular}{|c|c|c|c|c|c|c|c|}
\hline Ammotrypanella cf. arctica & & & & & & & \\
\hline $\begin{array}{l}\text { Mclntosh, } 1878 \\
\text { Ammotrypanella cf. arctica }\end{array}$ & 2514 & 1 & 13.07.93 & $66 \div 34^{\prime} 08^{\prime \prime}$ & $25 \div 13^{\prime} 68^{\prime \prime}$ & 465 & -0.34 \\
\hline $\begin{array}{l}\text { Mclntosh, } 1878 \\
\text { Ammotrypanella cf. arctica }\end{array}$ & 2697 & 9 & 02.09 .94 & 6410'20" & $2743^{\prime} 10^{\prime \prime}$ & 1042 & 4.20 \\
\hline $\begin{array}{l}\text { McIntosh, } 1878 \\
\text { Ammotrypanella cf. arctica }\end{array}$ & 2698 & 1 & 02.09 .94 & $64 \div 10^{\prime} 50^{\prime \prime}$ & $27 \div 42^{\prime} 60^{\prime \prime}$ & 1038 & 4.20 \\
\hline $\begin{array}{l}\text { Mclntosh, } 1878 \\
\text { Ammotrypanella cf. arctica }\end{array}$ & 2700 & 8 & 02.09 .94 & $64^{\circ} 05^{\prime} 60^{\prime \prime}$ & $27050^{\prime} 00^{\prime \prime}$ & 1105 & 3.84 \\
\hline $\begin{array}{l}\text { McIntosh, } 1878 \\
\text { Ammotrypanella cf. arctica }\end{array}$ & 2701 & 37 & 02.09 .94 & $64 \div 05^{\prime} 50^{\prime \prime}$ & 27우'ㅇ" & 1121 & 3.84 \\
\hline $\begin{array}{l}\text { McIntosh, } 1878 \\
\text { Ammotrypanella cf. arctica }\end{array}$ & 2704 & 16 & 02.09 .94 & $63 \div 50^{\prime} 50^{\prime \prime}$ & $27 \div 42^{\prime} 80^{\prime \prime}$ & 1295 & 3.80 \\
\hline $\begin{array}{l}\text { McIntosh, } 1878 \\
\text { Ammotrypanella cf. arctica }\end{array}$ & 2706 & 6 & 03.09 .94 & $63 \div 55^{\prime} 80^{\prime \prime}$ & $28 \div 16 ' 30^{\prime \prime}$ & 1406 & 3.71 \\
\hline $\begin{array}{l}\text { McIntosh, } 1878 \\
\text { Ammotrypanella cf. arctica }\end{array}$ & 2707 & 8 & 03.09 .94 & $63 \div 55^{\prime} 30^{\prime \prime}$ & $28 \div 16^{\prime} 80^{\prime \prime}$ & 1407 & 3.71 \\
\hline $\begin{array}{l}\text { McIntosh, } 1878 \\
\text { Ammotrypanella cf. arctica }\end{array}$ & 2773 & 1 & 03.08 .95 & 6914'89" & $14016^{\prime} 52^{\prime \prime}$ & 1629 & -0.86 \\
\hline $\begin{array}{l}\text { McIntosh, } 1878 \\
\text { Ammotrypanella cf. arctica }\end{array}$ & 2777 & 1 & 03.08 .95 & $68 \div 36^{\prime} 80^{\prime \prime}$ & $14 \div 40^{\prime} 70^{\prime \prime}$ & 1556 & -0.78 \\
\hline $\begin{array}{l}\text { Mclntosh, } 1878 \\
\text { Ammotrypanella cf. arctica }\end{array}$ & 2859 & 38 & 29.08 .95 & 61이'22" & 16-52'86" & 2270 & 2.37 \\
\hline $\begin{array}{l}\text { McIntosh, } 1878 \\
\text { Ammotrypanella cf. arctica }\end{array}$ & 2860 & 63 & 30.08 .95 & 61녀'43" & $16057^{\prime} 48^{\prime \prime}$ & 2295 & 2.60 \\
\hline $\begin{array}{l}\text { McIntosh, } 1878 \\
\text { Ammotrypanella cf. arctica }\end{array}$ & 2863 & 30 & 30.08 .95 & 61ㅇ1'18" & $18^{\circ} 02^{\prime} 57^{\prime \prime}$ & 2400 & 2.07 \\
\hline $\begin{array}{l}\text { Mclntosh, } 1878 \\
\text { Ammotrypanella cf. arctica }\end{array}$ & 2903 & 4 & 24.08 .96 & $65 \div 22^{\prime} 80^{\prime \prime}$ & 28이'63" & 1066 & 4.78 \\
\hline $\begin{array}{l}\text { Mclntosh, } 1878 \\
\text { Ammotrypanella cf. arctica }\end{array}$ & 2908 & 8 & 25.08 .96 & 6515'67" & $28=50^{\prime} 27^{\prime \prime}$ & 1301 & 3.96 \\
\hline $\begin{array}{l}\text { McIntosh, } 1878 \\
\text { Ammotrypanella cf. arctica }\end{array}$ & 2912 & 5 & 25.08 .96 & 6511'01" & 290'18" & 1456 & 3.90 \\
\hline $\begin{array}{l}\text { McIntosh, } 1878 \\
\text { Ammotrypanella cf. arctica }\end{array}$ & 3012 & 19 & 07.07.97 & $6122^{\prime} 20^{\prime \prime}$ & 15이' $98 "$ & 2133 & 3.29 \\
\hline $\begin{array}{l}\text { McIntosh, } 1878 \\
\text { Ammotrypanella cf. arctica }\end{array}$ & 3072 & 1 & 12.07 .97 & 61이'65" & 150'15" & 2082 & 2.83 \\
\hline $\begin{array}{l}\text { Mclntosh, } 1878 \\
\text { Ammotrypanella cf. arctica }\end{array}$ & 3073 & 9 & 12.07 .97 & 61ㅇ5'78" & 150'ㄱ' & 2083 & 2.83 \\
\hline $\begin{array}{l}\text { McIntosh, } 1878 \\
\text { Ammotrypanella cf. arctica }\end{array}$ & 3075 & 4 & 13.07 .97 & $62 \circ 00 ' 19^{\prime \prime}$ & 1559'97" & 2192 & 3.07 \\
\hline $\begin{array}{l}\text { McIntosh, } 1878 \\
\text { Ammotrypanella cf. arctica }\end{array}$ & 3161 & 5 & 25.07 .00 & $62 \div 37^{\prime} 08^{\prime \prime}$ & 2321'79" & 1250 & 3.61 \\
\hline $\begin{array}{l}\text { McIntosh, } 1878 \\
\text { Ammotrypanella cf. arctica }\end{array}$ & 3167 & 12 & 26.07 .00 & $60 \div 54 ' 88^{\prime \prime}$ & $22 \div 47 ' 26 "$ & 1897 & 2.98 \\
\hline $\begin{array}{l}\text { McIntosh, } 1878 \\
\text { Ammotrypanella cf. arctica }\end{array}$ & 3173 & 1 & 28.07 .00 & $60 \div 05 ' 38 "$ & 2051'23" & 2709 & 2.68 \\
\hline $\begin{array}{l}\text { McIntosh, } 1878 \\
\text { Ammotrypanella cf. arctica }\end{array}$ & 3204 & 75 & 08.07.01 & 64ㅇ51'71" & 7ㅇ54'56" & 2613 & -0.83 \\
\hline $\begin{array}{l}\text { McIntosh, } 1878 \\
\text { Ammotrypanella cf. arctica }\end{array}$ & 3208 & 75 & 09.07.01 & 6543'93" & 7으'95" & 2002 & -0.87 \\
\hline $\begin{array}{l}\text { McIntosh, } 1878 \\
\text { Ammotrypanella cf. arctica }\end{array}$ & 3210 & 54 & 09.07.01 & 6613'66" & 651'77" & 2544 & -0.87 \\
\hline $\begin{array}{l}\text { McIntosh, } 1878 \\
\text { Ammotrypanella cf. arctica }\end{array}$ & 3214 & 695 & 10.07.01 & 6701'78" & 6011'83" & 3003 & -0.90 \\
\hline $\begin{array}{l}\text { Mclntosh, } 1878 \\
\text { Ammotrypanella cf. arctica }\end{array}$ & 3216 & 56 & 11.07 .01 & $67 \div 05^{\prime} 86^{\prime \prime}$ & 7은'12" & 2014 & -0.86 \\
\hline $\begin{array}{l}\text { McIntosh, } 1878 \\
\text { Ammotrypanella cf. arctica }\end{array}$ & 3219 & 35 & 11.07 .01 & 67ㅇ14'79" & 828'06" & 1642 & -0.82 \\
\hline $\begin{array}{l}\text { Mclntosh, } 1878 \\
\text { Ammotrypanella cf. arctica }\end{array}$ & 3222 & 3 & 11.07 .01 & 67ㅇ5'ㄱ" & 805'94" & 1525 & -0.83 \\
\hline $\begin{array}{l}\text { McIntosh, } 1878 \\
\text { Ammotrypanella cf. arctica }\end{array}$ & 3504 & 1 & 02.09 .02 & $62^{\circ} 01^{\prime} 46^{\prime \prime}$ & 1949'15" & 1733 & 3.09 \\
\hline Mclntosh, 1878 & 3509 & 7 & 03.09 .02 & $62 \div 02^{\prime} 40^{\prime \prime}$ & 193'71" & 1678 & 2.70 \\
\hline
\end{tabular}




\begin{tabular}{|c|c|c|c|c|c|c|c|}
\hline Ammotrypanella cf. arctica & & & & & & & \\
\hline $\begin{array}{l}\text { Mclntosh, } 1878 \\
\text { Ammotrypanella cf. arctica }\end{array}$ & 3514 & 1 & 04.09.02 & $62 \div 25^{\prime} 59^{\prime \prime}$ & $19 \div 46^{\prime} 15^{\prime \prime}$ & 1780 & 2.93 \\
\hline $\begin{array}{l}\text { Mclntosh, } 1878 \\
\text { Ammotrypanella cf. arctica }\end{array}$ & 3570 & 4 & 04.09 .03 & $6342^{\prime} 71^{\prime \prime}$ & $29910^{\prime} 36^{\prime \prime}$ & 1819 & 3.24 \\
\hline $\begin{array}{l}\text { McIntosh, } 1878 \\
\text { Ammotrypanella cf. arctica }\end{array}$ & 3573 & 2 & 05.09 .03 & $63 \div 22^{\prime} 49^{\prime \prime}$ & $29 \div 54 ' 85^{\prime \prime}$ & 2359 & 3.06 \\
\hline $\begin{array}{l}\text { Mclntosh, } 1878 \\
\text { Ammotrypanella cf. arctica }\end{array}$ & 3621 & 4 & 14.07 .04 & 6629'39" & 9044 '80" & 1475 & -0.78 \\
\hline $\begin{array}{l}\text { McIntosh, } 1878 \\
\text { Ammotrypanella cf. arctica }\end{array}$ & 3624 & 19 & 14.07 .04 & $66059^{\prime} 48^{\prime \prime}$ & $8048^{\prime} 73^{\prime \prime}$ & 1628 & -0.82 \\
\hline $\begin{array}{l}\text { McIntosh, } 1878 \\
\text { Ammotrypanella cf. arctica }\end{array}$ & 3628 & 15 & 15.07 .04 & 67ำ19'53" & 9o32'76" & 1609 & -0.81 \\
\hline $\begin{array}{l}\text { McIntosh, } 1878 \\
\text { Ammotrypanella cf. arctica }\end{array}$ & 3632 & 100 & 16.07 .04 & 6800'92" & 9-14'78" & 1727 & -0.82 \\
\hline $\begin{array}{l}\text { McIntosh, } 1878 \\
\text { Ammotrypanella cf. arctica }\end{array}$ & 3633 & 191 & 17.07.04 & $68 \div 25^{\prime} 12^{\prime \prime}$ & $8 \div 57^{\prime} 72^{\prime \prime}$ & 1952 & -0.84 \\
\hline $\begin{array}{l}\text { McIntosh, } 1878 \\
\text { Ammotrypanella cf. arctica }\end{array}$ & 3636 & 7 & 17.07.04 & 6849'71" & 9-14'42" & 1844 & -0.81 \\
\hline $\begin{array}{l}\text { McIntosh, } 1878 \\
\text { Ammotrypanella cf. arctica }\end{array}$ & 3637 & 175 & 17.07.04 & $68 \div 26^{\prime} 92^{\prime \prime}$ & $10908^{\prime} 75^{\prime \prime}$ & 2069 & -0.80 \\
\hline $\begin{array}{l}\text { Mclntosh, } 1878 \\
\text { Ammotrypanella cf. arctica }\end{array}$ & 3638 & 1 & 18.07.04 & $68 \div 26^{\prime} 63^{\prime \prime}$ & $10010^{\prime} 58^{\prime \prime}$ & 2065 & -0.80 \\
\hline $\begin{array}{l}\text { McIntosh, } 1878 \\
\text { Ammotrypanella cf. arctica }\end{array}$ & 3640 & 120 & 18.07.04 & 67ㅇ5'63" & $10 \circ 02^{\prime} 61^{\prime \prime}$ & 1915 & -0.82 \\
\hline $\begin{array}{l}\text { McIntosh, } 1878 \\
\text { Ammotrypanella cf. arctica }\end{array}$ & 3645 & 12 & 21.07 .04 & $67 \div 24^{\prime} 22^{\prime \prime}$ & $10 \cong 40 ' 59^{\prime \prime}$ & 1703 & -0.81 \\
\hline $\begin{array}{l}\text { Mclntosh, } 1878 \\
\text { Ammotrypanella cf. arctica }\end{array}$ & 3648 & 41 & 22.07 .04 & $68 \div 57^{\prime} 10^{\prime \prime}$ & $10 \cong 32^{\prime} 80^{\prime \prime}$ & 2215 & -0.79 \\
\hline $\begin{array}{l}\text { McIntosh, } 1878 \\
\text { Ammotrypanella cf. arctica }\end{array}$ & 3649 & 9 & 22.07 .04 & $68 \div 56^{\prime} 45^{\prime \prime}$ & $10 \div 35^{\prime} 65^{\prime \prime}$ & 2214 & -0.79 \\
\hline $\begin{array}{l}\text { McIntosh, } 1878 \\
\text { Ammotrypanella cf. arctica }\end{array}$ & 3652 & 146 & 22.07 .04 & $69904 ' 00^{\prime \prime}$ & $13 \div 33^{\prime} 85^{\prime \prime}$ & 1678 & -0.81 \\
\hline $\begin{array}{l}\text { McIntosh, } 1878 \\
\text { Ammotrypanella cf. arctica }\end{array}$ & 2027 & 1 & 23.07.91 & 67ำ1'82" & $13 \div 20^{\prime} 58^{\prime \prime}$ & 1648 & -0.76 \\
\hline $\begin{array}{l}\text { McIntosh, } 1878 \\
\text { Ammotrypanella cf. arctica }\end{array}$ & 2077 & 2 & 03.07.92 & 67ㅇ4'51" & 17웅'38" & 1048 & -0.52 \\
\hline $\begin{array}{l}\text { Mclntosh, } 1878 \\
\text { Ammotrypanella cf. arctica }\end{array}$ & 2257 & 28 & 05.09 .92 & 6314'61" & 26029'14" & 1209 & 4.09 \\
\hline $\begin{array}{l}\text { McIntosh, } 1878 \\
\text { Ammotrypanella cf. arctica }\end{array}$ & 2310 & 116 & 11.09 .92 & 6334'09" & $22 \div 42^{\prime} 73^{\prime \prime}$ & 172 & 7.30 \\
\hline $\begin{array}{l}\text { McIntosh, } 1878 \\
\text { Ammotrypanella cf. arctica }\end{array}$ & 2403 & 12 & 01.07 .93 & 6302'90" & 21ㄴㅇ'60" & 838 & 5.49 \\
\hline $\begin{array}{l}\text { McIntosh, } 1878 \\
\text { Ammotrypanella cf. arctica }\end{array}$ & 2404 & 1 & 01.07 .93 & 6302'30" & 21ㅇ5ㅇ' $80^{\prime \prime}$ & 802 & 5.49 \\
\hline $\begin{array}{l}\text { McIntosh, } 1878 \\
\text { Ammotrypanella cf. arctica }\end{array}$ & 2406 & 6 & 01.07 .93 & $62 \div 59^{\prime} 20^{\prime \prime}$ & 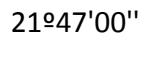 & 934 & 4.57 \\
\hline $\begin{array}{l}\text { Mclntosh, } 1878 \\
\text { Ammotrypanella cf. arctica }\end{array}$ & 2410 & 2 & 02.07 .93 & $62 \div 51^{\prime} 60^{\prime \prime}$ & 21ㄴ4'10" & 1074 & 4.00 \\
\hline $\begin{array}{l}\text { McIntosh, } 1878 \\
\text { Ammotrypanella cf. arctica }\end{array}$ & 2415 & 7 & 02.07 .93 & 6300'18" & 21ㅇo'54" & 819 & 5.36 \\
\hline $\begin{array}{l}\text { McIntosh, } 1878 \\
\text { Ammotrypanella cf. arctica }\end{array}$ & 2429 & 1 & 03.07 .93 & $63 \div 07^{\prime} 00^{\prime \prime}$ & $19-56^{\prime} 60^{\prime \prime}$ & 1072 & 4.80 \\
\hline $\begin{array}{l}\text { McIntosh, } 1878 \\
\text { Ammotrypanella cf. arctica }\end{array}$ & 2430 & 1 & 03.07.93 & 630' & $19-57^{\prime} 20^{\prime \prime}$ & 1016 & 4.80 \\
\hline $\begin{array}{l}\text { McIntosh, } 1878 \\
\text { Ammotrypanella cf. arctica }\end{array}$ & 2475 & 2 & 05.07.93 & $63 \div 04 ' 20^{\prime \prime}$ & 21ㅇ'ㅇ' & 842 & 5.54 \\
\hline $\begin{array}{l}\text { McIntosh, } 1878 \\
\text { Ammotrypanella cf. arctica }\end{array}$ & 2514 & 1 & 13.07 .93 & 66ㅇ'이" & 2513'68" & 465 & -0.34 \\
\hline $\begin{array}{l}\text { Mclntosh, } 1878 \\
\text { Ammotrypanella cf. arctica }\end{array}$ & 2697 & 9 & 02.09 .94 & $64 \div 10^{\prime} 20^{\prime \prime}$ & 27우'ㅇ' & 1042 & 4.20 \\
\hline $\begin{array}{l}\text { McIntosh, } 1878 \\
\text { Ammotrypanella cf. arctica }\end{array}$ & 2698 & 1 & 02.09 .94 & $64 \div 10^{\prime} 50^{\prime \prime}$ & $27 \div 42^{\prime} 60^{\prime \prime}$ & 1038 & 4.20 \\
\hline Mclntosh, 1878 & 2700 & 8 & 02.09 .94 & 640'ㅇ' & 27응'00" & 1105 & 3.84 \\
\hline
\end{tabular}




\begin{tabular}{|c|c|c|c|c|c|c|c|}
\hline Ammotrypanella cf. arctica & & & & & & & \\
\hline $\begin{array}{l}\text { Mclntosh, } 1878 \\
\text { Ammotrypanella cf. arctica }\end{array}$ & 2701 & 37 & 02.09.94 & $64 \div 05^{\prime} 50^{\prime \prime}$ & 27ㅇ4'70" & 1121 & 3.84 \\
\hline $\begin{array}{l}\text { Mclntosh, } 1878 \\
\text { Ammotrypanella cf. arctica }\end{array}$ & 2704 & 16 & 02.09 .94 & $63 \div 50^{\prime} 50^{\prime \prime}$ & $2742^{\prime} 80^{\prime \prime}$ & 1295 & 3.80 \\
\hline $\begin{array}{l}\text { McIntosh, } 1878 \\
\text { Ammotrypanella cf. arctica }\end{array}$ & 2706 & 6 & 03.09.94 & $63 \div 55^{\prime} 80^{\prime \prime}$ & 2816'30" & 1406 & 3.71 \\
\hline $\begin{array}{l}\text { Mclntosh, } 1878 \\
\text { Ammotrypanella cf. arctica }\end{array}$ & 2707 & 8 & 03.09 .94 & 635'ㅇ' & 28ำ16'80" & 1407 & 3.71 \\
\hline $\begin{array}{l}\text { McIntosh, } 1878 \\
\text { Ammotrypanella cf. arctica }\end{array}$ & 2773 & 1 & 03.08 .95 & 69o14'89" & $14016 ' 52^{\prime \prime}$ & 1629 & -0.86 \\
\hline $\begin{array}{l}\text { McIntosh, } 1878 \\
\text { Ammotrypanella cf. arctica }\end{array}$ & 2777 & 1 & 03.08 .95 & $68 \div 36^{\prime} 80^{\prime \prime}$ & $14 \div 40^{\prime} 70^{\prime \prime}$ & 1556 & -0.78 \\
\hline $\begin{array}{l}\text { McIntosh, } 1878 \\
\text { Ammotrypanella cf. arctica }\end{array}$ & 2859 & 38 & 29.08 .95 & $61950 ' 22 "$ & $16052^{\prime} 86^{\prime \prime}$ & 2270 & 2.37 \\
\hline $\begin{array}{l}\text { Mclntosh, } 1878 \\
\text { Ammotrypanella cf. arctica }\end{array}$ & 2860 & 63 & 30.08 .95 & $61943^{\prime} 43^{\prime \prime}$ & $16957^{\prime} 48^{\prime \prime}$ & 2295 & 2.60 \\
\hline $\begin{array}{l}\text { McIntosh, } 1878 \\
\text { Ammotrypanella cf. arctica }\end{array}$ & 2863 & 30 & 30.08 .95 & 611ㅇ'18" & $18 \div 02^{\prime} 57^{\prime \prime}$ & 2400 & 2.07 \\
\hline $\begin{array}{l}\text { McIntosh, } 1878 \\
\text { Ammotrypanella cf. arctica }\end{array}$ & 2903 & 4 & 24.08 .96 & $65 \div 22^{\prime} 80^{\prime \prime}$ & $28 \div 20 ' 63^{\prime \prime}$ & 1066 & 4.78 \\
\hline $\begin{array}{l}\text { Mclntosh, } 1878 \\
\text { Ammotrypanella cf. arctica }\end{array}$ & 2908 & 8 & 25.08 .96 & 6515'67" & $28 \div 50 ' 27 "$ & 1301 & 3.96 \\
\hline $\begin{array}{l}\text { McIntosh, } 1878 \\
\text { Ammotrypanella cf. arctica }\end{array}$ & 2912 & 5 & 25.08 .96 & 6511'01" & 29o04'18" & 1456 & 3.90 \\
\hline $\begin{array}{l}\text { Mclntosh, } 1878 \\
\text { Ammotrypanella cf. arctica }\end{array}$ & 3012 & 19 & 07.07.97 & $6122^{\prime} 20^{\prime \prime}$ & $15 \div 18^{\prime} 98^{\prime \prime}$ & 2133 & 3.29 \\
\hline $\begin{array}{l}\text { Mclntosh, } 1878 \\
\text { Ammotrypanella cf. arctica }\end{array}$ & 3072 & 1 & 12.07 .97 & 61이'65" & 150'15" & 2082 & 2.83 \\
\hline $\begin{array}{l}\text { Mclntosh, } 1878 \\
\text { Ammotrypanella cf. arctica }\end{array}$ & 3073 & 9 & 12.07 .97 & 61ㅇ5'78" & $15 \div 08^{\prime} 33^{\prime \prime}$ & 2083 & 2.83 \\
\hline $\begin{array}{l}\text { McIntosh, } 1878 \\
\text { Ammotrypanella cf. arctica }\end{array}$ & 3075 & 4 & 13.07.97 & $62 \div 00 ' 19 "$ & 1559'97" & 2192 & 3.07 \\
\hline $\begin{array}{l}\text { McIntosh, } 1878 \\
\text { Ammotrypanella cf. arctica }\end{array}$ & 3161 & 5 & 25.07 .00 & $62 \div 37^{\prime} 08^{\prime \prime}$ & 2321'79" & 1250 & 3.61 \\
\hline $\begin{array}{l}\text { McIntosh, } 1878 \\
\text { Ammotrypanella cf. arctica }\end{array}$ & 3167 & 12 & 26.07 .00 & $60 \div 54 ' 88^{\prime \prime}$ & $22 \circ 47^{\prime} 26^{\prime \prime}$ & 1897 & 2.98 \\
\hline $\begin{array}{l}\text { Mclntosh, } 1878 \\
\text { Ammotrypanella cf. arctica }\end{array}$ & 3173 & 1 & 28.07 .00 & $60 \div 05 ' 38 "$ & 2051'23" & 2709 & 2.68 \\
\hline $\begin{array}{l}\text { McIntosh, } 1878 \\
\text { Ammotrypanella cf. arctica }\end{array}$ & 3204 & 75 & 08.07.01 & 6451'71" & 7ㅇ54'56" & 2613 & -0.83 \\
\hline $\begin{array}{l}\text { McIntosh, } 1878 \\
\text { Ammotrypanella cf. arctica }\end{array}$ & 3208 & 75 & 09.07.01 & 6543'93" & 7으'95" & 2002 & -0.87 \\
\hline $\begin{array}{l}\text { McIntosh, } 1878 \\
\text { Ammotrypanella cf. arctica }\end{array}$ & 3210 & 54 & 09.07.01 & 66o13'66" & 6o51'77" & 2544 & -0.87 \\
\hline $\begin{array}{l}\text { McIntosh, } 1878 \\
\text { Ammotrypanella cf. arctica }\end{array}$ & 3214 & 695 & 10.07.01 & 6701'78" & 6011'83" & 3003 & -0.90 \\
\hline $\begin{array}{l}\text { McIntosh, } 1878 \\
\text { Ammotrypanella cf. arctica }\end{array}$ & 3216 & 56 & 11.07 .01 & 6705'86" & 7윽'12" & 2014 & -0.86 \\
\hline $\begin{array}{l}\text { McIntosh, } 1878 \\
\text { Ammotrypanella cf. arctica }\end{array}$ & 3219 & 35 & 11.07 .01 & 67ㅇ14'79" & 828'06" & 1642 & -0.82 \\
\hline $\begin{array}{l}\text { McIntosh, } 1878 \\
\text { Ammotrypanella cf. arctica }\end{array}$ & 3222 & 3 & 11.07 .01 & 67ㅇ5'77" & 805'94" & 1525 & -0.83 \\
\hline $\begin{array}{l}\text { McIntosh, } 1878 \\
\text { Ammotrypanella cf. arctica }\end{array}$ & 3504 & 1 & 02.09 .02 & $62 \circ 01^{\prime} 46^{\prime \prime}$ & 1949'15" & 1733 & 3.09 \\
\hline $\begin{array}{l}\text { McIntosh, } 1878 \\
\text { Ammotrypanella cf. arctica }\end{array}$ & 3509 & 7 & 03.09.02 & $62^{\circ} 02^{\prime} 40^{\prime \prime}$ & 193'71" & 1678 & 2.70 \\
\hline $\begin{array}{l}\text { McIntosh, } 1878 \\
\text { Ammotrypanella cf. arctica }\end{array}$ & 3514 & 1 & 04.09 .02 & $62 \div 25^{\prime} 59^{\prime \prime}$ & 1946'15" & 1780 & 2.93 \\
\hline $\begin{array}{l}\text { Mclntosh, } 1878 \\
\text { Ammotrypanella cf. arctica }\end{array}$ & 3570 & 4 & 04.09 .03 & $63 \div 42^{\prime} 71^{\prime \prime}$ & 2910'36" & 1819 & 3.24 \\
\hline $\begin{array}{l}\text { McIntosh, } 1878 \\
\text { Ammotrypanella cf. arctica }\end{array}$ & 3573 & 2 & 05.09 .03 & $63 \div 22^{\prime} 49^{\prime \prime}$ & 29o54'85" & 2359 & 3.06 \\
\hline Mclntosh, 1878 & 3621 & 4 & 14.07 .04 & 6629'39" & 944'80" & 1475 & -0.78 \\
\hline
\end{tabular}




\begin{tabular}{|c|c|c|c|c|c|c|c|}
\hline Ammotrypanella cf. arctica & & & & & & & \\
\hline $\begin{array}{l}\text { Mclntosh, } 1878 \\
\text { Ammotrypanella cf. arctica }\end{array}$ & 3624 & 19 & 14.07.04 & $66059^{\prime} 48^{\prime \prime}$ & $8048^{\prime} 73^{\prime \prime}$ & 1628 & -0.82 \\
\hline $\begin{array}{l}\text { Mclntosh, } 1878 \\
\text { Ammotrypanella cf. arctica }\end{array}$ & 3628 & 15 & 15.07 .04 & 67ำ19'53" & 9o32'76" & 1609 & -0.81 \\
\hline $\begin{array}{l}\text { McIntosh, } 1878 \\
\text { Ammotrypanella cf. arctica }\end{array}$ & 3632 & 100 & 16.07.04 & $68 \div 00 ' 92^{\prime \prime}$ & 914'78" & 1727 & -0.82 \\
\hline $\begin{array}{l}\text { Mclntosh, } 1878 \\
\text { Ammotrypanella cf. arctica }\end{array}$ & 3633 & 191 & 17.07.04 & $68025^{\prime} 12^{\prime \prime}$ & $8 \div 57^{\prime} 72^{\prime \prime}$ & 1952 & -0.84 \\
\hline $\begin{array}{l}\text { McIntosh, } 1878 \\
\text { Ammotrypanella cf. arctica }\end{array}$ & 3636 & 7 & 17.07.04 & 6849'71" & 9o14'42" & 1844 & -0.81 \\
\hline $\begin{array}{l}\text { McIntosh, } 1878 \\
\text { Ammotrypanella cf. arctica }\end{array}$ & 3637 & 175 & 17.07.04 & $68 \div 26^{\prime} 92^{\prime \prime}$ & $10 \circ 08^{\prime} 75^{\prime \prime}$ & 2069 & -0.80 \\
\hline $\begin{array}{l}\text { McIntosh, } 1878 \\
\text { Ammotrypanella cf. arctica }\end{array}$ & 3638 & 1 & 18.07.04 & $68 \div 26^{\prime} 63^{\prime \prime}$ & $10010^{\prime} 58^{\prime \prime}$ & 2065 & -0.80 \\
\hline $\begin{array}{l}\text { Mclntosh, } 1878 \\
\text { Ammotrypanella cf. arctica }\end{array}$ & 3640 & 120 & 18.07.04 & 67ㅇ5'63" & $10902^{\prime} 61^{\prime \prime}$ & 1915 & -0.82 \\
\hline $\begin{array}{l}\text { McIntosh, } 1878 \\
\text { Ammotrypanella cf. arctica }\end{array}$ & 3645 & 12 & 21.07 .04 & $67 \div 24 ' 22^{\prime \prime}$ & $10 \div 40 ' 59^{\prime \prime}$ & 1703 & -0.81 \\
\hline $\begin{array}{l}\text { McIntosh, } 1878 \\
\text { Ammotrypanella cf. arctica }\end{array}$ & 3648 & 41 & 22.07 .04 & $68 \div 57^{\prime} 10^{\prime \prime}$ & $10 \circ 32^{\prime} 80^{\prime \prime}$ & 2215 & -0.79 \\
\hline $\begin{array}{l}\text { Mclntosh, } 1878 \\
\text { Ammotrypanella cf. arctica }\end{array}$ & 3649 & 9 & 22.07 .04 & $68 \div 56^{\prime} 45^{\prime \prime}$ & $10 \cong 35^{\prime} 65^{\prime \prime}$ & 2214 & -0.79 \\
\hline $\begin{array}{l}\text { McIntosh, } 1878 \\
\text { Ammotrypanella cf. arctica }\end{array}$ & 3652 & 146 & 22.07 .04 & $69 \circ 04^{\prime} 00^{\prime \prime}$ & 13ㅇ'ㅇ' $85^{\prime \prime}$ & 1678 & -0.81 \\
\hline $\begin{array}{l}\text { McIntosh, } 1878 \\
\text { Ammotrypanella cf. arctica }\end{array}$ & 2027 & 1 & 23.07 .91 & 67ㅇ1'82" & $13 \div 20^{\prime} 58^{\prime \prime}$ & 1648 & -0.76 \\
\hline $\begin{array}{l}\text { Mclntosh, } 1878 \\
\text { Ammotrypanella cf. arctica }\end{array}$ & 2077 & 2 & 03.07 .92 & 67눙'51" & 17ㅇ1'ㅇ' & 1048 & -0.52 \\
\hline $\begin{array}{l}\text { Mclntosh, } 1878 \\
\text { Ammotrypanella cf. arctica }\end{array}$ & 2257 & 28 & 05.09 .92 & 6314'61" & $26929^{\prime} 14 "$ & 1209 & 4.09 \\
\hline $\begin{array}{l}\text { McIntosh, } 1878 \\
\text { Ammotrypanella cf. arctica }\end{array}$ & 2310 & 116 & 11.09 .92 & 6334'09" & $22 \circ 42^{\prime} 73^{\prime \prime}$ & 172 & 7.30 \\
\hline $\begin{array}{l}\text { McIntosh, } 1878 \\
\text { Ammotrypanella cf. arctica }\end{array}$ & 2403 & 12 & 01.07 .93 & 630'ㅇ' & 21ㄴㅇ'60" & 838 & 5.49 \\
\hline $\begin{array}{l}\text { McIntosh, } 1878 \\
\text { Ammotrypanella cf. arctica }\end{array}$ & 2404 & 1 & 01.07 .93 & $63 \div 02 ' 30^{\prime \prime}$ & 21ㅇ50'80" & 802 & 5.49 \\
\hline $\begin{array}{l}\text { Mclntosh, } 1878 \\
\text { Ammotrypanella cf. arctica }\end{array}$ & 2406 & 6 & 01.07 .93 & $62 \div 59^{\prime} 20^{\prime \prime}$ & 21ㄴㄱ'00" & 934 & 4.57 \\
\hline $\begin{array}{l}\text { McIntosh, } 1878 \\
\text { Ammotrypanella cf. arctica }\end{array}$ & 2410 & 2 & 02.07 .93 & $62 \div 51^{\prime} 60^{\prime \prime}$ & 21ㄴ4'10" & 1074 & 4.00 \\
\hline $\begin{array}{l}\text { McIntosh, } 1878 \\
\text { Ammotrypanella cf. arctica }\end{array}$ & 2415 & 7 & 02.07 .93 & 6300'18" & 21000'54" & 819 & 5.36 \\
\hline $\begin{array}{l}\text { McIntosh, } 1878 \\
\text { Ammotrypanella cf. arctica }\end{array}$ & 2429 & 1 & 03.07 .93 & 630'00" & $19-566^{\prime} 60^{\prime \prime}$ & 1072 & 4.80 \\
\hline $\begin{array}{l}\text { McIntosh, } 1878 \\
\text { Ammotrypanella cf. arctica }\end{array}$ & 2430 & 1 & 03.07 .93 & 630ㄱ'90" & $19-57^{\prime} 20^{\prime \prime}$ & 1016 & 4.80 \\
\hline $\begin{array}{l}\text { Mclntosh, } 1878 \\
\text { Ammotrypanella cf. arctica }\end{array}$ & 2475 & 2 & 05.07 .93 & $63 \div 04 ' 20^{\prime \prime}$ & 21여'90" & 842 & 5.54 \\
\hline $\begin{array}{l}\text { McIntosh, } 1878 \\
\text { Ammotrypanella cf. arctica }\end{array}$ & 2514 & 1 & 13.07 .93 & $66034 ' 08^{\prime \prime}$ & 2513'68" & 465 & -0.34 \\
\hline $\begin{array}{l}\text { McIntosh, } 1878 \\
\text { Ammotrypanella cf. arctica }\end{array}$ & 2697 & 9 & 02.09 .94 & 64ำ10'20" & 27우'10" & 1042 & 4.20 \\
\hline $\begin{array}{l}\text { McIntosh, } 1878 \\
\text { Ammotrypanella cf. arctica }\end{array}$ & 2698 & 1 & 02.09 .94 & $64 \div 10^{\prime} 50^{\prime \prime}$ & 27ㅇ4'60" & 1038 & 4.20 \\
\hline $\begin{array}{l}\text { McIntosh, } 1878 \\
\text { Ammotrypanella cf. arctica }\end{array}$ & 2700 & 8 & 02.09 .94 & $64^{\circ} 05^{\prime} 60^{\prime \prime}$ & $27 \div 50 ' 00^{\prime \prime}$ & 1105 & 3.84 \\
\hline $\begin{array}{l}\text { McIntosh, } 1878 \\
\text { Ammotrypanella cf. arctica }\end{array}$ & 2701 & 37 & 02.09 .94 & $64^{\circ} 05^{\prime} 50^{\prime \prime}$ & 27ㄴ9'70" & 1121 & 3.84 \\
\hline $\begin{array}{l}\text { Mclntosh, } 1878 \\
\text { Ammotrypanella cf. arctica }\end{array}$ & 2704 & 16 & 02.09 .94 & $63 \div 50^{\prime} 50^{\prime \prime}$ & $27 \div 42^{\prime} 80^{\prime \prime}$ & 1295 & 3.80 \\
\hline $\begin{array}{l}\text { McIntosh, } 1878 \\
\text { Ammotrypanella cf. arctica }\end{array}$ & 2706 & 6 & 03.09 .94 & $63 \div 55^{\prime} 80^{\prime \prime}$ & 2816'30" & 1406 & 3.71 \\
\hline Mclntosh, 1878 & 2707 & 8 & 03.09 .94 & 6355'30" & 2816'80" & 1407 & 3.71 \\
\hline
\end{tabular}




\begin{tabular}{|c|c|c|c|c|c|c|c|}
\hline Ammotrypanella cf. arctica & & & & & & & \\
\hline $\begin{array}{l}\text { Mclntosh, } 1878 \\
\text { Ammotrypanella cf. arctica }\end{array}$ & 2773 & 1 & 03.08 .95 & 6914'89" & $14 \div 16^{\prime} 52^{\prime \prime}$ & 1629 & -0.86 \\
\hline $\begin{array}{l}\text { Mclntosh, } 1878 \\
\text { Ammotrypanella cf. arctica }\end{array}$ & 2777 & 1 & 03.08 .95 & $68 \div 366^{\prime} 80^{\prime \prime}$ & $14 \div 40^{\prime} 70^{\prime \prime}$ & 1556 & -0.78 \\
\hline $\begin{array}{l}\text { McIntosh, } 1878 \\
\text { Ammotrypanella cf. arctica }\end{array}$ & 2859 & 38 & 29.08 .95 & $61950 ' 22 "$ & $16052^{\prime} 86^{\prime \prime}$ & 2270 & 2.37 \\
\hline $\begin{array}{l}\text { Mclntosh, } 1878 \\
\text { Ammotrypanella cf. arctica }\end{array}$ & 2860 & 63 & 30.08 .95 & $61043^{\prime} 43^{\prime \prime}$ & $16057^{\prime} 48^{\prime \prime}$ & 2295 & 2.60 \\
\hline $\begin{array}{l}\text { McIntosh, } 1878 \\
\text { Ammotrypanella cf. arctica }\end{array}$ & 2863 & 30 & 30.08 .95 & 6110'18" & $18 \div 02^{\prime} 57^{\prime \prime}$ & 2400 & 2.07 \\
\hline $\begin{array}{l}\text { McIntosh, } 1878 \\
\text { Ammotrypanella cf. arctica }\end{array}$ & 2903 & 4 & 24.08 .96 & $65 \div 22^{\prime} 80^{\prime \prime}$ & $28 \div 20^{\prime} 63^{\prime \prime}$ & 1066 & 4.78 \\
\hline $\begin{array}{l}\text { McIntosh, } 1878 \\
\text { Ammotrypanella cf. arctica }\end{array}$ & 2908 & 8 & 25.08 .96 & $65 \div 15^{\prime} 67^{\prime \prime}$ & $28 \div 50 ' 27^{\prime \prime}$ & 1301 & 3.96 \\
\hline $\begin{array}{l}\text { Mclntosh, } 1878 \\
\text { Ammotrypanella cf. arctica }\end{array}$ & 2912 & 5 & 25.08 .96 & 651'01" & $29904^{\prime} 18^{\prime \prime}$ & 1456 & 3.90 \\
\hline $\begin{array}{l}\text { McIntosh, } 1878 \\
\text { Ammotrypanella cf. arctica }\end{array}$ & 3012 & 19 & 07.07.97 & $6122^{\prime} 20^{\prime \prime}$ & $15 \div 18^{\prime} 98^{\prime \prime}$ & 2133 & 3.29 \\
\hline $\begin{array}{l}\text { McIntosh, } 1878 \\
\text { Ammotrypanella cf. arctica }\end{array}$ & 3072 & 1 & 12.07 .97 & $61953^{\prime} 65^{\prime \prime}$ & $15 \div 08^{\prime} 15^{\prime \prime}$ & 2082 & 2.83 \\
\hline $\begin{array}{l}\text { Mclntosh, } 1878 \\
\text { Ammotrypanella cf. arctica }\end{array}$ & 3073 & 9 & 12.07 .97 & 61ㅇ5'78" & 150'ㄱ' & 2083 & 2.83 \\
\hline $\begin{array}{l}\text { McIntosh, } 1878 \\
\text { Ammotrypanella cf. arctica }\end{array}$ & 3075 & 4 & 13.07.97 & $62 \circ 00 ' 19^{\prime \prime}$ & 1559'97" & 2192 & 3.07 \\
\hline $\begin{array}{l}\text { Mclntosh, } 1878 \\
\text { Ammotrypanella cf. arctica }\end{array}$ & 3161 & 5 & 25.07 .00 & $62 \div 37^{\prime} 08^{\prime \prime}$ & $23 \div 21^{\prime} 79^{\prime \prime}$ & 1250 & 3.61 \\
\hline $\begin{array}{l}\text { Mclntosh, } 1878 \\
\text { Ammotrypanella cf. arctica }\end{array}$ & 3167 & 12 & 26.07 .00 & $60 \div 54 ' 88^{\prime \prime}$ & $22 \div 47 ' 26 "$ & 1897 & 2.98 \\
\hline $\begin{array}{l}\text { Mclntosh, } 1878 \\
\text { Ammotrypanella cf. arctica }\end{array}$ & 3173 & 1 & 28.07 .00 & $60 \circ 05^{\prime} 38^{\prime \prime}$ & $20 \circ 51 ' 23 "$ & 2709 & 2.68 \\
\hline $\begin{array}{l}\text { McIntosh, } 1878 \\
\text { Ammotrypanella cf. arctica }\end{array}$ & 3204 & 75 & 08.07.01 & 6451'71" & 7ㅇ5'ㄷ'" & 2613 & -0.83 \\
\hline $\begin{array}{l}\text { McIntosh, } 1878 \\
\text { Ammotrypanella cf. arctica }\end{array}$ & 3208 & 75 & 09.07.01 & 6543'93" & 7으'95" & 2002 & -0.87 \\
\hline $\begin{array}{l}\text { McIntosh, } 1878 \\
\text { Ammotrypanella cf. arctica }\end{array}$ & 3210 & 54 & 09.07.01 & 66o13'66" & 651'77" & 2544 & -0.87 \\
\hline $\begin{array}{l}\text { Mclntosh, } 1878 \\
\text { Ammotrypanella cf. arctica }\end{array}$ & 3214 & 695 & 10.07 .01 & 6701'78" & 6011'83" & 3003 & -0.90 \\
\hline $\begin{array}{l}\text { McIntosh, } 1878 \\
\text { Ammotrypanella cf. arctica }\end{array}$ & 3216 & 56 & 11.07 .01 & 67ㅇ5'86" & 7윽'12" & 2014 & -0.86 \\
\hline $\begin{array}{l}\text { Mclntosh, } 1878 \\
\text { Ammotrypanella cf. arctica }\end{array}$ & 3219 & 35 & 11.07 .01 & 67ㅇ14'79" & 828'06" & 1642 & -0.82 \\
\hline $\begin{array}{l}\text { McIntosh, } 1878 \\
\text { Ammotrypanella cf. arctica }\end{array}$ & 3222 & 3 & 11.07 .01 & 67ㅇ5'77" & 805'94" & 1525 & -0.83 \\
\hline $\begin{array}{l}\text { McIntosh, } 1878 \\
\text { Ammotrypanella cf. arctica }\end{array}$ & 3504 & 1 & 02.09 .02 & $62 \circ 01^{\prime} 46^{\prime \prime}$ & 1949'15" & 1733 & 3.09 \\
\hline $\begin{array}{l}\text { Mclntosh, } 1878 \\
\text { Ammotrypanella cf. arctica }\end{array}$ & 3509 & 7 & 03.09.02 & $62^{\circ} 02^{\prime} 40^{\prime \prime}$ & 193'71" & 1678 & 2.70 \\
\hline $\begin{array}{l}\text { McIntosh, } 1878 \\
\text { Ammotrypanella cf. arctica }\end{array}$ & 3514 & 1 & 04.09 .02 & $62 \div 25^{\prime} 59^{\prime \prime}$ & $19 \circ 46^{\prime} 15^{\prime \prime}$ & 1780 & 2.93 \\
\hline $\begin{array}{l}\text { McIntosh, } 1878 \\
\text { Ammotrypanella cf. arctica }\end{array}$ & 3570 & 4 & 04.09 .03 & 6342'71" & 2910'36" & 1819 & 3.24 \\
\hline $\begin{array}{l}\text { McIntosh, } 1878 \\
\text { Ammotrypanella cf. arctica }\end{array}$ & 3573 & 2 & 05.09 .03 & $63 \div 22^{\prime} 49^{\prime \prime}$ & 29o54'85" & 2359 & 3.06 \\
\hline $\begin{array}{l}\text { Mclntosh, } 1878 \\
\text { Ammotrypanella cf. arctica }\end{array}$ & 3621 & 4 & 14.07.04 & 6629'39" & $9 \circ 44$ ' $80^{\prime \prime}$ & 1475 & -0.78 \\
\hline $\begin{array}{l}\text { McIntosh, } 1878 \\
\text { Ammotrypanella cf. arctica }\end{array}$ & 3624 & 19 & 14.07 .04 & $66059^{\prime} 48^{\prime \prime}$ & $8048^{\prime} 73^{\prime \prime}$ & 1628 & -0.82 \\
\hline $\begin{array}{l}\text { Mclntosh, } 1878 \\
\text { Ammotrypanella cf. arctica }\end{array}$ & 3628 & 15 & 15.07 .04 & 67ㅇ19'53" & 9-32'76" & 1609 & -0.81 \\
\hline $\begin{array}{l}\text { McIntosh, } 1878 \\
\text { Ammotrypanella cf. arctica }\end{array}$ & 3632 & 100 & 16.07 .04 & 6800'92" & 914'78" & 1727 & -0.82 \\
\hline Mclntosh, 1878 & 3633 & 191 & 17.07.04 & $68 \div 25^{\prime} 12^{\prime \prime}$ & 8ㄴㄱ'72" & 1952 & -0.84 \\
\hline
\end{tabular}




\begin{tabular}{|c|c|c|c|c|c|c|c|}
\hline Ammotrypanella cf. arctica & & & & & & & \\
\hline $\begin{array}{l}\text { Mclntosh, } 1878 \\
\text { Ammotrypanella cf. arctica }\end{array}$ & 3636 & 7 & 17.07.04 & 6849'71" & $9014 ' 42^{\prime \prime}$ & 1844 & -0.81 \\
\hline $\begin{array}{l}\text { Mclntosh, } 1878 \\
\text { Ammotrypanella cf. arctica }\end{array}$ & 3637 & 175 & 17.07 .04 & $68 \div 26^{\prime} 92^{\prime \prime}$ & $10908^{\prime} 75^{\prime \prime}$ & 2069 & -0.80 \\
\hline $\begin{array}{l}\text { McIntosh, } 1878 \\
\text { Ammotrypanella cf. arctica }\end{array}$ & 3638 & 1 & 18.07.04 & $68 \div 26^{\prime} 63^{\prime \prime}$ & $10 \cong 10^{\prime} 58^{\prime \prime}$ & 2065 & -0.80 \\
\hline $\begin{array}{l}\text { Mclntosh, } 1878 \\
\text { Ammotrypanella cf. arctica }\end{array}$ & 3640 & 120 & 18.07.04 & 67ㅇ5'63" & $10 \circ 02^{\prime} 61^{\prime \prime}$ & 1915 & -0.82 \\
\hline $\begin{array}{l}\text { McIntosh, } 1878 \\
\text { Ammotrypanella cf. arctica }\end{array}$ & 3645 & 12 & 21.07 .04 & 67으'22" & $10 \div 40 ' 59^{\prime \prime}$ & 1703 & -0.81 \\
\hline $\begin{array}{l}\text { McIntosh, } 1878 \\
\text { Ammotrypanella cf. arctica }\end{array}$ & 3648 & 41 & 22.07 .04 & $68 \div 57^{\prime} 10^{\prime \prime}$ & $10032^{\prime} 80^{\prime \prime}$ & 2215 & -0.79 \\
\hline $\begin{array}{l}\text { McIntosh, } 1878 \\
\text { Ammotrypanella cf. arctica }\end{array}$ & 3649 & 9 & 22.07 .04 & $68 \div 56^{\prime} 45^{\prime \prime}$ & $10 \div 35^{\prime} 65^{\prime \prime}$ & 2214 & -0.79 \\
\hline $\begin{array}{l}\text { Mclntosh, } 1878 \\
\text { Ammotrypanella cf. arctica }\end{array}$ & 3652 & 146 & 22.07 .04 & $69904 ' 00^{\prime \prime}$ & $13 \div 33^{\prime} 85^{\prime \prime}$ & 1678 & -0.81 \\
\hline $\begin{array}{l}\text { McIntosh, } 1878 \\
\text { Ammotrypanella cf. arctica }\end{array}$ & 2027 & 1 & 23.07.91 & 67ำ1'82" & $13 \div 20^{\prime} 58^{\prime \prime}$ & 1648 & -0.76 \\
\hline $\begin{array}{l}\text { McIntosh, } 1878 \\
\text { Ammotrypanella cf. arctica }\end{array}$ & 2077 & 2 & 03.07.92 & 67ㅇ4' $51^{\prime \prime}$ & 17웅'38" & 1048 & -0.52 \\
\hline $\begin{array}{l}\text { McIntosh, } 1878 \\
\text { Ammotrypanella cf. arctica }\end{array}$ & 2257 & 28 & 05.09 .92 & 6314'61" & 2629'14" & 1209 & 4.09 \\
\hline $\begin{array}{l}\text { McIntosh, } 1878 \\
\text { Ammotrypanella cf. arctica }\end{array}$ & 2310 & 116 & 11.09 .92 & 6334'09" & $22 \circ 42^{\prime} 73^{\prime \prime}$ & 172 & 7.30 \\
\hline $\begin{array}{l}\text { Mclntosh, } 1878 \\
\text { Ammotrypanella cf. arctica }\end{array}$ & 2403 & 12 & 01.07.93 & 630ํ'90" & 21ㅇํ'60" & 838 & 5.49 \\
\hline $\begin{array}{l}\text { Mclntosh, } 1878 \\
\text { Ammotrypanella cf. arctica }\end{array}$ & 2404 & 1 & 01.07 .93 & 6302'30" & 21ㅇ50'80" & 802 & 5.49 \\
\hline $\begin{array}{l}\text { Mclntosh, } 1878 \\
\text { Ammotrypanella cf. arctica }\end{array}$ & 2406 & 6 & 01.07.93 & $62 \div 59 ' 20^{\prime \prime}$ & 21ㅇ4'00" & 934 & 4.57 \\
\hline $\begin{array}{l}\text { McIntosh, } 1878 \\
\text { Ammotrypanella cf. arctica }\end{array}$ & 2410 & 2 & 02.07 .93 & $62 \div 51^{\prime} 60^{\prime \prime}$ & 21ㄴ''10" & 1074 & 4.00 \\
\hline $\begin{array}{l}\text { McIntosh, } 1878 \\
\text { Ammotrypanella cf. arctica }\end{array}$ & 2415 & 7 & 02.07 .93 & 63000'18" & 21ㅇo'54" & 819 & 5.36 \\
\hline $\begin{array}{l}\text { McIntosh, } 1878 \\
\text { Ammotrypanella cf. arctica }\end{array}$ & 2429 & 1 & 03.07 .93 & $63 \div 07^{\prime} 00^{\prime \prime}$ & $19-56^{\prime} 60^{\prime \prime}$ & 1072 & 4.80 \\
\hline $\begin{array}{l}\text { Mclntosh, } 1878 \\
\text { Ammotrypanella cf. arctica }\end{array}$ & 2430 & 1 & 03.07 .93 & $63 \div 07^{\prime} 90^{\prime \prime}$ & $19-57^{\prime} 20^{\prime \prime}$ & 1016 & 4.80 \\
\hline $\begin{array}{l}\text { McIntosh, } 1878 \\
\text { Ammotrypanella cf. arctica }\end{array}$ & 2475 & 2 & 05.07 .93 & 6304'20" & 21여'90" & 842 & 5.54 \\
\hline $\begin{array}{l}\text { McIntosh, } 1878 \\
\text { Ammotrypanella cf. arctica }\end{array}$ & 2514 & 1 & 13.07 .93 & 66-34'08" & 2513'68" & 465 & -0.34 \\
\hline $\begin{array}{l}\text { McIntosh, } 1878 \\
\text { Ammotrypanella cf. arctica }\end{array}$ & 2697 & 9 & 02.09 .94 & 64ำ10'20" & 27여'10" & 1042 & 4.20 \\
\hline $\begin{array}{l}\text { McIntosh, } 1878 \\
\text { Ammotrypanella cf. arctica }\end{array}$ & 2698 & 1 & 02.09 .94 & 64ำ10'50" & 27우'ㅇ' & 1038 & 4.20 \\
\hline $\begin{array}{l}\text { Mclntosh, } 1878 \\
\text { Ammotrypanella cf. arctica }\end{array}$ & 2700 & 8 & 02.09 .94 & $64^{\circ} 05^{\prime} 60^{\prime \prime}$ & $27 \div 50^{\prime} 00^{\prime \prime}$ & 1105 & 3.84 \\
\hline $\begin{array}{l}\text { McIntosh, } 1878 \\
\text { Ammotrypanella cf. arctica }\end{array}$ & 2701 & 37 & 02.09 .94 & $64^{\circ} 05^{\prime} 50^{\prime \prime}$ & 27ㄴ9'70" & 1121 & 3.84 \\
\hline $\begin{array}{l}\text { McIntosh, } 1878 \\
\text { Ammotrypanella cf. arctica }\end{array}$ & 2704 & 16 & 02.09 .94 & $63 \div 50^{\prime} 50^{\prime \prime}$ & 27ㅇ4' $80^{\prime \prime}$ & 1295 & 3.80 \\
\hline $\begin{array}{l}\text { McIntosh, } 1878 \\
\text { Ammotrypanella cf. arctica }\end{array}$ & 2706 & 6 & 03.09.94 & $63 \div 55^{\prime} 80^{\prime \prime}$ & 2816'30" & 1406 & 3.71 \\
\hline $\begin{array}{l}\text { McIntosh, } 1878 \\
\text { Ammotrypanella cf. arctica }\end{array}$ & 2707 & 8 & 03.09.94 & 635'ㅇ' & 2816'80" & 1407 & 3.71 \\
\hline $\begin{array}{l}\text { McIntosh, } 1878 \\
\text { Ammotrypanella cf. arctica }\end{array}$ & 2773 & 1 & 03.08 .95 & 6914'89" & 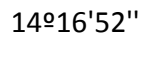 & 1629 & -0.86 \\
\hline $\begin{array}{l}\text { Mclntosh, } 1878 \\
\text { Ammotrypanella cf. arctica }\end{array}$ & 2777 & 1 & 03.08 .95 & $68 \div 36^{\prime} 80^{\prime \prime}$ & $14 \div 40^{\prime} 70^{\prime \prime}$ & 1556 & -0.78 \\
\hline $\begin{array}{l}\text { McIntosh, } 1878 \\
\text { Ammotrypanella cf. arctica }\end{array}$ & 2859 & 38 & 29.08 .95 & 61이'22" & $16052^{\prime} 86^{\prime \prime}$ & 2270 & 2.37 \\
\hline Mclntosh, 1878 & 2860 & 63 & 30.08 .95 & $61043^{\prime} 43^{\prime \prime}$ & $16057^{\prime} 48^{\prime \prime}$ & 2295 & 2.60 \\
\hline
\end{tabular}




\begin{tabular}{|c|c|c|c|c|c|c|c|}
\hline Ammotrypanella cf. arctica & & & & & & & \\
\hline $\begin{array}{l}\text { Mclntosh, } 1878 \\
\text { Ammotrypanella cf. arctica }\end{array}$ & 2863 & 30 & 30.08 .95 & 611''ㅇ" & $18 \div 02^{\prime} 57^{\prime \prime}$ & 2400 & 2.07 \\
\hline $\begin{array}{l}\text { Mclntosh, } 1878 \\
\text { Ammotrypanella cf. arctica }\end{array}$ & 2903 & 4 & 24.08 .96 & $65 \div 22^{\prime} 80^{\prime \prime}$ & $28920^{\prime} 63^{\prime \prime}$ & 1066 & 4.78 \\
\hline $\begin{array}{l}\text { McIntosh, } 1878 \\
\text { Ammotrypanella cf. arctica }\end{array}$ & 2908 & 8 & 25.08 .96 & $65 \div 15^{\prime} 67^{\prime \prime}$ & $28 \div 50 ' 27 "$ & 1301 & 3.96 \\
\hline $\begin{array}{l}\text { Mclntosh, } 1878 \\
\text { Ammotrypanella cf. arctica }\end{array}$ & 2912 & 5 & 25.08 .96 & 6511'01" & 29o04'18" & 1456 & 3.90 \\
\hline $\begin{array}{l}\text { McIntosh, } 1878 \\
\text { Ammotrypanella cf. arctica }\end{array}$ & 3012 & 19 & 07.07.97 & $6122^{\prime} 20^{\prime \prime}$ & 15ㅇํ' & 2133 & 3.29 \\
\hline $\begin{array}{l}\text { McIntosh, } 1878 \\
\text { Ammotrypanella cf. arctica }\end{array}$ & 3072 & 1 & 12.07 .97 & $61053^{\prime} 65^{\prime \prime}$ & $15 \div 08^{\prime} 15^{\prime \prime}$ & 2082 & 2.83 \\
\hline $\begin{array}{l}\text { McIntosh, } 1878 \\
\text { Ammotrypanella cf. arctica }\end{array}$ & 3073 & 9 & 12.07 .97 & 61으' $78^{\prime \prime}$ & $15 \div 08^{\prime} 33^{\prime \prime}$ & 2083 & 2.83 \\
\hline $\begin{array}{l}\text { McIntosh, } 1878 \\
\text { Ammotrypanella cf. arctica }\end{array}$ & 3075 & 4 & 13.07 .97 & $62^{\circ} 00^{\prime} 19^{\prime \prime}$ & 1559'97" & 2192 & 3.07 \\
\hline $\begin{array}{l}\text { McIntosh, } 1878 \\
\text { Ammotrypanella cf. arctica }\end{array}$ & 3161 & 5 & 25.07 .00 & $62 \div 37^{\prime} 08^{\prime \prime}$ & 2321'79" & 1250 & 3.61 \\
\hline $\begin{array}{l}\text { McIntosh, } 1878 \\
\text { Ammotrypanella cf. arctica }\end{array}$ & 3167 & 12 & 26.07 .00 & $60 \div 54 ' 88 "$ & $22 \div 47^{\prime} 26^{\prime \prime}$ & 1897 & 2.98 \\
\hline $\begin{array}{l}\text { McIntosh, } 1878 \\
\text { Ammotrypanella cf. arctica }\end{array}$ & 3173 & 1 & 28.07 .00 & $60 \circ 05^{\prime} 38^{\prime \prime}$ & $20-51 ' 23^{\prime \prime}$ & 2709 & 2.68 \\
\hline $\begin{array}{l}\text { McIntosh, } 1878 \\
\text { Ammotrypanella cf. arctica }\end{array}$ & 3204 & 75 & 08.07.01 & 64이'1" & 7ㅇ5'56" & 2613 & -0.83 \\
\hline $\begin{array}{l}\text { McIntosh, } 1878 \\
\text { Ammotrypanella cf. arctica }\end{array}$ & 3208 & 75 & 09.07.01 & 6543'93" & 7으'95" & 2002 & -0.87 \\
\hline $\begin{array}{l}\text { Mclntosh, } 1878 \\
\text { Ammotrypanella cf. arctica }\end{array}$ & 3210 & 54 & 09.07.01 & 66o13'66" & 6-51'77" & 2544 & -0.87 \\
\hline $\begin{array}{l}\text { Mclntosh, } 1878 \\
\text { Ammotrypanella cf. arctica }\end{array}$ & 3214 & 695 & 10.07.01 & 67웅' & 6011'83" & 3003 & -0.90 \\
\hline $\begin{array}{l}\text { Mclntosh, } 1878 \\
\text { Ammotrypanella cf. arctica }\end{array}$ & 3216 & 56 & 11.07 .01 & 6705'86" & 7윽'12" & 2014 & -0.86 \\
\hline $\begin{array}{l}\text { McIntosh, } 1878 \\
\text { Ammotrypanella cf. arctica }\end{array}$ & 3219 & 35 & 11.07 .01 & 67ㅇ14'79" & 828'06" & 1642 & -0.82 \\
\hline $\begin{array}{l}\text { McIntosh, } 1878 \\
\text { Ammotrypanella cf. arctica }\end{array}$ & 3222 & 3 & 11.07 .01 & 67ㅇ5'77" & 805'94" & 1525 & -0.83 \\
\hline $\begin{array}{l}\text { Mclntosh, } 1878 \\
\text { Ammotrypanella cf. arctica }\end{array}$ & 3504 & 1 & 02.09 .02 & $62^{\circ} 01^{\prime} 46^{\prime \prime}$ & 1949'15" & 1733 & 3.09 \\
\hline $\begin{array}{l}\text { McIntosh, } 1878 \\
\text { Ammotrypanella cf. arctica }\end{array}$ & 3509 & 7 & 03.09.02 & $62 \circ 02^{\prime} 40^{\prime \prime}$ & 1938'71" & 1678 & 2.70 \\
\hline $\begin{array}{l}\text { McIntosh, } 1878 \\
\text { Ammotrypanella cf. arctica }\end{array}$ & 3514 & 1 & 04.09 .02 & $62 \div 25^{\prime} 59^{\prime \prime}$ & 1946'15" & 1780 & 2.93 \\
\hline $\begin{array}{l}\text { McIntosh, } 1878 \\
\text { Ammotrypanella cf. arctica }\end{array}$ & 3570 & 4 & 04.09 .03 & 6342'71" & 29o10'36" & 1819 & 3.24 \\
\hline $\begin{array}{l}\text { McIntosh, } 1878 \\
\text { Ammotrypanella cf. arctica }\end{array}$ & 3573 & 2 & 05.09 .03 & $63 \div 22^{\prime} 49^{\prime \prime}$ & 29o54'85" & 2359 & 3.06 \\
\hline $\begin{array}{l}\text { Mclntosh, } 1878 \\
\text { Ammotrypanella cf. arctica }\end{array}$ & 3621 & 4 & 14.07 .04 & 6629'39" & $9 \div 44 ' 80^{\prime \prime}$ & 1475 & -0.78 \\
\hline $\begin{array}{l}\text { McIntosh, } 1878 \\
\text { Ammotrypanella cf. arctica }\end{array}$ & 3624 & 19 & 14.07 .04 & $66059^{\prime} 48^{\prime \prime}$ & $8 \div 48^{\prime} 73^{\prime \prime}$ & 1628 & -0.82 \\
\hline $\begin{array}{l}\text { McIntosh, } 1878 \\
\text { Ammotrypanella cf. arctica }\end{array}$ & 3628 & 15 & 15.07 .04 & 67ㅇ19'53" & 932'76" & 1609 & -0.81 \\
\hline $\begin{array}{l}\text { McIntosh, } 1878 \\
\text { Ammotrypanella cf. arctica }\end{array}$ & 3632 & 100 & 16.07 .04 & 6800'92" & 914'78" & 1727 & -0.82 \\
\hline $\begin{array}{l}\text { Mclntosh, } 1878 \\
\text { Ammotrypanella cf. arctica }\end{array}$ & 3633 & 191 & 17.07.04 & $68 \div 25^{\prime} 12^{\prime \prime}$ & $8 \div 57^{\prime} 72^{\prime \prime}$ & 1952 & -0.84 \\
\hline $\begin{array}{l}\text { McIntosh, } 1878 \\
\text { Ammotrypanella cf. arctica }\end{array}$ & 3636 & 7 & 17.07 .04 & 6849'71" & 914'42" & 1844 & -0.81 \\
\hline $\begin{array}{l}\text { Mclntosh, } 1878 \\
\text { Ammotrypanella cf. arctica }\end{array}$ & 3637 & 175 & 17.07.04 & 6826'92" & $10 \circ 08^{\prime} 75^{\prime \prime}$ & 2069 & -0.80 \\
\hline $\begin{array}{l}\text { McIntosh, } 1878 \\
\text { Ammotrypanella cf. arctica }\end{array}$ & 3638 & 1 & 18.07.04 & $68 \div 26^{\prime} 63^{\prime \prime}$ & 1010'58" & 2065 & -0.80 \\
\hline Mclntosh, 1878 & 3640 & 120 & 18.07.04 & 67ㅇ5'63" & $10 \circ 02^{\prime} 61^{\prime \prime}$ & 1915 & -0.82 \\
\hline
\end{tabular}




\begin{tabular}{|c|c|c|c|c|c|c|c|}
\hline Ammotrypanella cf. arctica & & & & & & & \\
\hline $\begin{array}{l}\text { Mclntosh, } 1878 \\
\text { Ammotrypanella cf. arctica }\end{array}$ & 3645 & 12 & 21.07 .04 & $67 \div 24^{\prime} 22^{\prime \prime}$ & $10 \div 40^{\prime} 59^{\prime \prime}$ & 1703 & -0.81 \\
\hline $\begin{array}{l}\text { Mclntosh, } 1878 \\
\text { Ammotrypanella cf. arctica }\end{array}$ & 3648 & 41 & 22.07 .04 & $68957^{\prime} 10^{\prime \prime}$ & $10932^{\prime} 80^{\prime \prime}$ & 2215 & -0.79 \\
\hline $\begin{array}{l}\text { McIntosh, } 1878 \\
\text { Ammotrypanella cf. arctica }\end{array}$ & 3649 & 9 & 22.07 .04 & $68 \div 56^{\prime} 45^{\prime \prime}$ & $10035^{\prime} 65^{\prime \prime}$ & 2214 & -0.79 \\
\hline $\begin{array}{l}\text { Mclntosh, } 1878 \\
\text { Ammotrypanella cf. arctica }\end{array}$ & 3652 & 146 & 22.07 .04 & 690'00" & $13033^{\prime} 85^{\prime \prime}$ & 1678 & -0.81 \\
\hline $\begin{array}{l}\text { McIntosh, } 1878 \\
\text { Ammotrypanella cf. arctica }\end{array}$ & 2027 & 1 & 23.07 .91 & 67ำ1'82" & $13 \div 20 ' 58 "$ & 1648 & -0.76 \\
\hline $\begin{array}{l}\text { McIntosh, } 1878 \\
\text { Ammotrypanella cf. arctica }\end{array}$ & 2077 & 2 & 03.07 .92 & $67 \div 40^{\prime} 51^{\prime \prime}$ & 17웅'38" & 1048 & -0.52 \\
\hline $\begin{array}{l}\text { McIntosh, } 1878 \\
\text { Ammotrypanella cf. arctica }\end{array}$ & 2257 & 28 & 05.09 .92 & 6314'61" & 26029'14" & 1209 & 4.09 \\
\hline $\begin{array}{l}\text { McIntosh, } 1878 \\
\text { Ammotrypanella cf. arctica }\end{array}$ & 2310 & 116 & 11.09 .92 & 6334'09" & $22 \div 42^{\prime} 73^{\prime \prime}$ & 172 & 7.30 \\
\hline $\begin{array}{l}\text { McIntosh, } 1878 \\
\text { Ammotrypanella cf. arctica }\end{array}$ & 2403 & 12 & 01.07 .93 & 630' $90^{\prime \prime}$ & 21ㄴㅇ'60" & 838 & 5.49 \\
\hline $\begin{array}{l}\text { McIntosh, } 1878 \\
\text { Ammotrypanella cf. arctica }\end{array}$ & 2404 & 1 & 01.07 .93 & $63 \div 02^{\prime} 30^{\prime \prime}$ & $21950 ' 80^{\prime \prime}$ & 802 & 5.49 \\
\hline $\begin{array}{l}\text { McIntosh, } 1878 \\
\text { Ammotrypanella cf. arctica }\end{array}$ & 2406 & 6 & 01.07 .93 & $62 \div 59^{\prime} 20^{\prime \prime}$ & $2147^{\prime} 00^{\prime \prime}$ & 934 & 4.57 \\
\hline $\begin{array}{l}\text { McIntosh, } 1878 \\
\text { Ammotrypanella cf. arctica }\end{array}$ & 2410 & 2 & 02.07 .93 & $62 \div 51^{\prime} 60^{\prime \prime}$ & 21ㅇㄴ'10" & 1074 & 4.00 \\
\hline $\begin{array}{l}\text { Mclntosh, } 1878 \\
\text { Ammotrypanella cf. arctica }\end{array}$ & 2415 & 7 & 02.07.93 & $63 \div 00 ' 18^{\prime \prime}$ & 21ㅇo'54" & 819 & 5.36 \\
\hline $\begin{array}{l}\text { Mclntosh, } 1878 \\
\text { Ammotrypanella cf. arctica }\end{array}$ & 2429 & 1 & 03.07 .93 & $63 \div 07^{\prime} 00^{\prime \prime}$ & $19-566^{\prime} 60^{\prime \prime}$ & 1072 & 4.80 \\
\hline $\begin{array}{l}\text { Mclntosh, } 1878 \\
\text { Ammotrypanella cf. arctica }\end{array}$ & 2430 & 1 & 03.07 .93 & 630ㄱ'90" & $19-57 ' 20^{\prime \prime}$ & 1016 & 4.80 \\
\hline $\begin{array}{l}\text { McIntosh, } 1878 \\
\text { Ammotrypanella cf. arctica }\end{array}$ & 2475 & 2 & 05.07 .93 & $63 \div 04 ' 20^{\prime \prime}$ & 21ㅇ'ㅇ' & 842 & 5.54 \\
\hline $\begin{array}{l}\text { McIntosh, } 1878 \\
\text { Ammotrypanella cf. arctica }\end{array}$ & 2514 & 1 & 13.07 .93 & $66034 ' 08^{\prime \prime}$ & 2513'68" & 465 & -0.34 \\
\hline $\begin{array}{l}\text { McIntosh, } 1878 \\
\text { Ammotrypanella cf. arctica }\end{array}$ & 2697 & 9 & 02.09 .94 & 6410'20" & 27여'10" & 1042 & 4.20 \\
\hline $\begin{array}{l}\text { Mclntosh, } 1878 \\
\text { Ammotrypanella cf. arctica }\end{array}$ & 2698 & 1 & 02.09 .94 & $64 \div 10^{\prime} 50^{\prime \prime}$ & $27 \div 42^{\prime} 60^{\prime \prime}$ & 1038 & 4.20 \\
\hline $\begin{array}{l}\text { McIntosh, } 1878 \\
\text { Ammotrypanella cf. arctica }\end{array}$ & 2700 & 8 & 02.09 .94 & 6405'60" & 27ㅇ5ㅇ'00" & 1105 & 3.84 \\
\hline $\begin{array}{l}\text { McIntosh, } 1878 \\
\text { Ammotrypanella cf. arctica }\end{array}$ & 2701 & 37 & 02.09 .94 & $64 \div 05^{\prime} 50^{\prime \prime}$ & 27ㅇ4'70" & 1121 & 3.84 \\
\hline $\begin{array}{l}\text { McIntosh, } 1878 \\
\text { Ammotrypanella cf. arctica }\end{array}$ & 2704 & 16 & 02.09 .94 & $63 \div 50 ' 50 "$ & 27ㅇ42'80" & 1295 & 3.80 \\
\hline $\begin{array}{l}\text { McIntosh, } 1878 \\
\text { Ammotrypanella cf. arctica }\end{array}$ & 2706 & 6 & 03.09 .94 & $63 \div 55^{\prime} 80^{\prime \prime}$ & 2816'30" & 1406 & 3.71 \\
\hline $\begin{array}{l}\text { McIntosh, } 1878 \\
\text { Ammotrypanella cf. arctica }\end{array}$ & 2707 & 8 & 03.09 .94 & $63 \div 55 ' 30 "$ & 2816'80" & 1407 & 3.71 \\
\hline $\begin{array}{l}\text { McIntosh, } 1878 \\
\text { Ammotrypanella cf. arctica }\end{array}$ & 2773 & 1 & 03.08 .95 & 6914'89" & $14^{\circ} 16^{\prime} 52^{\prime \prime}$ & 1629 & -0.86 \\
\hline $\begin{array}{l}\text { McIntosh, } 1878 \\
\text { Ammotrypanella cf. arctica }\end{array}$ & 2777 & 1 & 03.08 .95 & $68 \div 36^{\prime} 80^{\prime \prime}$ & $14 \div 40^{\prime} 70^{\prime \prime}$ & 1556 & -0.78 \\
\hline $\begin{array}{l}\text { McIntosh, } 1878 \\
\text { Ammotrypanella cf. arctica }\end{array}$ & 2859 & 38 & 29.08 .95 & $61950 ' 22 "$ & $16052^{\prime} 86^{\prime \prime}$ & 2270 & 2.37 \\
\hline $\begin{array}{l}\text { McIntosh, } 1878 \\
\text { Ammotrypanella cf. arctica }\end{array}$ & 2860 & 63 & 30.08 .95 & $61043^{\prime} 43^{\prime \prime}$ & $16057^{\prime} 48^{\prime \prime}$ & 2295 & 2.60 \\
\hline $\begin{array}{l}\text { McIntosh, } 1878 \\
\text { Ammotrypanella cf. arctica }\end{array}$ & 2863 & 30 & 30.08 .95 & 61ำ10'18" & $18^{\circ} 02^{\prime} 57^{\prime \prime}$ & 2400 & 2.07 \\
\hline $\begin{array}{l}\text { Mclntosh, } 1878 \\
\text { Ammotrypanella cf. arctica }\end{array}$ & 2903 & 4 & 24.08 .96 & $65 \div 22^{\prime} 80^{\prime \prime}$ & $28020^{\prime} 63^{\prime \prime}$ & 1066 & 4.78 \\
\hline $\begin{array}{l}\text { McIntosh, } 1878 \\
\text { Ammotrypanella cf. arctica }\end{array}$ & 2908 & 8 & 25.08 .96 & 6515'67" & $28 \div 50 ' 27^{\prime \prime}$ & 1301 & 3.96 \\
\hline Mclntosh, 1878 & 2912 & 5 & 25.08 .96 & 6511'01" & 290'18" & 1456 & 3.90 \\
\hline
\end{tabular}




\begin{tabular}{|c|c|c|c|c|c|c|c|}
\hline Ammotrypanella cf. arctica & & & & & & & \\
\hline $\begin{array}{l}\text { Mclntosh, } 1878 \\
\text { Ammotrypanella cf. arctica }\end{array}$ & 3012 & 19 & 07.07.97 & $61^{\circ} 22^{\prime} 20^{\prime \prime}$ & $15 \div 18^{\prime} 98^{\prime \prime}$ & 2133 & 3.29 \\
\hline $\begin{array}{l}\text { Mclntosh, } 1878 \\
\text { Ammotrypanella cf. arctica }\end{array}$ & 3072 & 1 & 12.07 .97 & $61953^{\prime} 65^{\prime \prime}$ & $15 \div 08^{\prime} 15^{\prime \prime}$ & 2082 & 2.83 \\
\hline $\begin{array}{l}\text { McIntosh, } 1878 \\
\text { Ammotrypanella cf. arctica }\end{array}$ & 3073 & 9 & 12.07.97 & $61053^{\prime} 78^{\prime \prime}$ & $15 \div 08^{\prime} 33^{\prime \prime}$ & 2083 & 2.83 \\
\hline $\begin{array}{l}\text { Mclntosh, } 1878 \\
\text { Ammotrypanella cf. arctica }\end{array}$ & 3075 & 4 & 13.07.97 & $62^{\circ} 00^{\prime} 19^{\prime \prime}$ & 1559'97" & 2192 & 3.07 \\
\hline $\begin{array}{l}\text { McIntosh, } 1878 \\
\text { Ammotrypanella cf. arctica }\end{array}$ & 3161 & 5 & 25.07 .00 & $62 \div 37^{\prime} 08^{\prime \prime}$ & 2321'79" & 1250 & 3.61 \\
\hline $\begin{array}{l}\text { McIntosh, } 1878 \\
\text { Ammotrypanella cf. arctica }\end{array}$ & 3167 & 12 & 26.07 .00 & $60 \div 54 ' 88^{\prime \prime}$ & $22 \circ 47^{\prime} 26^{\prime \prime}$ & 1897 & 2.98 \\
\hline $\begin{array}{l}\text { McIntosh, } 1878 \\
\text { Ammotrypanella cf. arctica }\end{array}$ & 3173 & 1 & 28.07 .00 & $60 \div 05 ' 38 "$ & $20 \div 51^{\prime} 23^{\prime \prime}$ & 2709 & 2.68 \\
\hline $\begin{array}{l}\text { McIntosh, } 1878 \\
\text { Ammotrypanella cf. arctica }\end{array}$ & 3204 & 75 & 08.07 .01 & 6451'71" & 7ㅇ5'ㄷ' & 2613 & -0.83 \\
\hline $\begin{array}{l}\text { McIntosh, } 1878 \\
\text { Ammotrypanella cf. arctica }\end{array}$ & 3208 & 75 & 09.07.01 & $65 \div 43^{\prime} 93^{\prime \prime}$ & 7ㅇo'95" & 2002 & -0.87 \\
\hline $\begin{array}{l}\text { McIntosh, } 1878 \\
\text { Ammotrypanella cf. arctica }\end{array}$ & 3210 & 54 & 09.07.01 & 6613'66" & 6o51'77" & 2544 & -0.87 \\
\hline $\begin{array}{l}\text { Mclntosh, } 1878 \\
\text { Ammotrypanella cf. arctica }\end{array}$ & 3214 & 695 & 10.07.01 & 6701'78" & 6011'83" & 3003 & -0.90 \\
\hline $\begin{array}{l}\text { McIntosh, } 1878 \\
\text { Ammotrypanella cf. arctica }\end{array}$ & 3216 & 56 & 11.07 .01 & 67ㅇ5'86" & 7으'12" & 2014 & -0.86 \\
\hline $\begin{array}{l}\text { McIntosh, } 1878 \\
\text { Ammotrypanella cf. arctica }\end{array}$ & 3219 & 35 & 11.07 .01 & 67ㅇ14'79" & $8 \div 28 ' 06^{\prime \prime}$ & 1642 & -0.82 \\
\hline $\begin{array}{l}\text { Mclntosh, } 1878 \\
\text { Ammotrypanella cf. arctica }\end{array}$ & 3222 & 3 & 11.07 .01 & 67ㅇ5'77" & 80'94" & 1525 & -0.83 \\
\hline $\begin{array}{l}\text { Mclntosh, } 1878 \\
\text { Ammotrypanella cf. arctica }\end{array}$ & 3504 & 1 & 02.09 .02 & $62^{\circ} 01^{\prime} 46^{\prime \prime}$ & 1949'15" & 1733 & 3.09 \\
\hline $\begin{array}{l}\text { McIntosh, } 1878 \\
\text { Ammotrypanella cf. arctica }\end{array}$ & 3509 & 7 & 03.09.02 & $62 \div 02^{\prime} 40^{\prime \prime}$ & 193'71" & 1678 & 2.70 \\
\hline $\begin{array}{l}\text { McIntosh, } 1878 \\
\text { Ammotrypanella cf. arctica }\end{array}$ & 3514 & 1 & 04.09 .02 & $62 \div 25^{\prime} 59^{\prime \prime}$ & $19-46^{\prime} 15^{\prime \prime}$ & 1780 & 2.93 \\
\hline $\begin{array}{l}\text { McIntosh, } 1878 \\
\text { Ammotrypanella cf. arctica }\end{array}$ & 3570 & 4 & 04.09 .03 & 6342'71" & 2910'36" & 1819 & 3.24 \\
\hline $\begin{array}{l}\text { Mclntosh, } 1878 \\
\text { Ammotrypanella cf. arctica }\end{array}$ & 3573 & 2 & 05.09 .03 & $63 \div 22^{\prime} 49^{\prime \prime}$ & 29-54'85" & 2359 & 3.06 \\
\hline $\begin{array}{l}\text { McIntosh, } 1878 \\
\text { Ammotrypanella cf. arctica }\end{array}$ & 3621 & 4 & 14.07 .04 & 66-29'39" & $9044 ' 80^{\prime \prime}$ & 1475 & -0.78 \\
\hline $\begin{array}{l}\text { Mclntosh, } 1878 \\
\text { Ammotrypanella cf. arctica }\end{array}$ & 3624 & 19 & 14.07.04 & $66059^{\prime} 48^{\prime \prime}$ & $8048^{\prime} 73^{\prime \prime}$ & 1628 & -0.82 \\
\hline $\begin{array}{l}\text { McIntosh, } 1878 \\
\text { Ammotrypanella cf. arctica }\end{array}$ & 3628 & 15 & 15.07 .04 & 67ㅇ19'53" & 932'76" & 1609 & -0.81 \\
\hline $\begin{array}{l}\text { McIntosh, } 1878 \\
\text { Ammotrypanella cf. arctica }\end{array}$ & 3632 & 100 & 16.07.04 & 6800'92" & 9o14'78" & 1727 & -0.82 \\
\hline $\begin{array}{l}\text { McIntosh, } 1878 \\
\text { Ammotrypanella cf. arctica }\end{array}$ & 3633 & 191 & 17.07 .04 & $68 \div 25^{\prime} 12^{\prime \prime}$ & 8익ㄹ" & 1952 & -0.84 \\
\hline $\begin{array}{l}\text { McIntosh, } 1878 \\
\text { Ammotrypanella cf. arctica }\end{array}$ & 3636 & 7 & 17.07.04 & 6849'71" & 9-14'42" & 1844 & -0.81 \\
\hline $\begin{array}{l}\text { McIntosh, } 1878 \\
\text { Ammotrypanella cf. arctica }\end{array}$ & 3637 & 175 & 17.07.04 & 68으' & $10 \circ 08^{\prime} 75^{\prime \prime}$ & 2069 & -0.80 \\
\hline $\begin{array}{l}\text { McIntosh, } 1878 \\
\text { Ammotrypanella cf. arctica }\end{array}$ & 3638 & 1 & 18.07.04 & $68 \div 26^{\prime} 63^{\prime \prime}$ & 1010'58" & 2065 & -0.80 \\
\hline $\begin{array}{l}\text { McIntosh, } 1878 \\
\text { Ammotrypanella cf. arctica }\end{array}$ & 3640 & 120 & 18.07.04 & 67ㅇ5'63" & $10 \circ 02^{\prime} 61^{\prime \prime}$ & 1915 & -0.82 \\
\hline $\begin{array}{l}\text { McIntosh, } 1878 \\
\text { Ammotrypanella cf. arctica }\end{array}$ & 3645 & 12 & 21.07 .04 & 67으'22' & $10 \circ 40^{\prime} 59^{\prime \prime}$ & 1703 & -0.81 \\
\hline $\begin{array}{l}\text { Mclntosh, } 1878 \\
\text { Ammotrypanella cf. arctica }\end{array}$ & 3648 & 41 & 22.07 .04 & $68957^{\prime} 10^{\prime \prime}$ & $10-32^{\prime} 80^{\prime \prime}$ & 2215 & -0.79 \\
\hline $\begin{array}{l}\text { McIntosh, } 1878 \\
\text { Ammotrypanella cf. arctica }\end{array}$ & 3649 & 9 & 22.07 .04 & $68 \div 56^{\prime} 45^{\prime \prime}$ & $10035^{\prime} 65^{\prime \prime}$ & 2214 & -0.79 \\
\hline Mclntosh, 1878 & 3652 & 146 & 22.07 .04 & $69 \circ 04^{\prime} 00^{\prime \prime}$ & $13 \div 33^{\prime} 85^{\prime \prime}$ & 1678 & -0.81 \\
\hline
\end{tabular}




\begin{tabular}{|c|c|c|c|c|c|c|c|}
\hline Ammotrypanella cf. arctica & & & & & & & \\
\hline $\begin{array}{l}\text { Mclntosh, } 1878 \\
\text { Ammotrypanella cf. arctica }\end{array}$ & 2027 & 1 & 23.07.91 & 67ำ11'82" & $13 \div 20^{\prime} 58^{\prime \prime}$ & 1648 & -0.76 \\
\hline $\begin{array}{l}\text { Mclntosh, } 1878 \\
\text { Ammotrypanella cf. arctica }\end{array}$ & 2077 & 2 & 03.07 .92 & $6740 ' 51^{\prime \prime}$ & $17010^{\prime} 38^{\prime \prime}$ & 1048 & -0.52 \\
\hline $\begin{array}{l}\text { McIntosh, } 1878 \\
\text { Ammotrypanella cf. arctica }\end{array}$ & 2257 & 28 & 05.09 .92 & 6314'61" & 2629'14" & 1209 & 4.09 \\
\hline $\begin{array}{l}\text { Mclntosh, } 1878 \\
\text { Ammotrypanella cf. arctica }\end{array}$ & 2310 & 116 & 11.09 .92 & 6334'09" & $22 \circ 42^{\prime} 73^{\prime \prime}$ & 172 & 7.30 \\
\hline $\begin{array}{l}\text { McIntosh, } 1878 \\
\text { Ammotrypanella cf. arctica }\end{array}$ & 2403 & 12 & 01.07 .93 & 630' $90^{\prime \prime}$ & 21여'60" & 838 & 5.49 \\
\hline $\begin{array}{l}\text { McIntosh, } 1878 \\
\text { Ammotrypanella cf. arctica }\end{array}$ & 2404 & 1 & 01.07 .93 & 630'ㅇ' & $21050^{\prime} 80^{\prime \prime}$ & 802 & 5.49 \\
\hline $\begin{array}{l}\text { McIntosh, } 1878 \\
\text { Ammotrypanella cf. arctica }\end{array}$ & 2406 & 6 & 01.07 .93 & $62 \div 59^{\prime} 20^{\prime \prime}$ & 214'00" & 934 & 4.57 \\
\hline $\begin{array}{l}\text { McIntosh, } 1878 \\
\text { Ammotrypanella cf. arctica }\end{array}$ & 2410 & 2 & 02.07 .93 & $62 \div 51^{\prime} 60^{\prime \prime}$ & 21ㄴ4'10" & 1074 & 4.00 \\
\hline $\begin{array}{l}\text { McIntosh, } 1878 \\
\text { Ammotrypanella cf. arctica }\end{array}$ & 2415 & 7 & 02.07 .93 & $63 \div 00 ' 18 "$ & 21000'54" & 819 & 5.36 \\
\hline $\begin{array}{l}\text { McIntosh, } 1878 \\
\text { Ammotrypanella cf. arctica }\end{array}$ & 2429 & 1 & 03.07 .93 & $63 \div 07^{\prime} 00^{\prime \prime}$ & $19-566^{\prime} 60^{\prime \prime}$ & 1072 & 4.80 \\
\hline $\begin{array}{l}\text { Mclntosh, } 1878 \\
\text { Ammotrypanella cf. arctica }\end{array}$ & 2430 & 1 & 03.07 .93 & 630'90" & $19 \div 57 ' 20^{\prime \prime}$ & 1016 & 4.80 \\
\hline $\begin{array}{l}\text { McIntosh, } 1878 \\
\text { Ammotrypanella cf. arctica }\end{array}$ & 2475 & 2 & 05.07 .93 & 630'ㅇ" & 21ㅇ'ㅇ' & 842 & 5.54 \\
\hline $\begin{array}{l}\text { Mclntosh, } 1878 \\
\text { Ammotrypanella cf. arctica }\end{array}$ & 2514 & 1 & 13.07.93 & 66-34'08" & $25 \div 13^{\prime} 68^{\prime \prime}$ & 465 & -0.34 \\
\hline $\begin{array}{l}\text { Mclntosh, } 1878 \\
\text { Ammotrypanella cf. arctica }\end{array}$ & 2697 & 9 & 02.09 .94 & $64 \div 10^{\prime} 20^{\prime \prime}$ & 27여'10" & 1042 & 4.20 \\
\hline $\begin{array}{l}\text { Mclntosh, } 1878 \\
\text { Ammotrypanella cf. arctica }\end{array}$ & 2698 & 1 & 02.09 .94 & 641ㅇ'50" & $2742^{\prime} 60^{\prime \prime}$ & 1038 & 4.20 \\
\hline $\begin{array}{l}\text { McIntosh, } 1878 \\
\text { Ammotrypanella cf. arctica }\end{array}$ & 2700 & 8 & 02.09 .94 & $64^{\circ} 05^{\prime} 60^{\prime \prime}$ & $27-50^{\prime} 00^{\prime \prime}$ & 1105 & 3.84 \\
\hline $\begin{array}{l}\text { McIntosh, } 1878 \\
\text { Ammotrypanella cf. arctica }\end{array}$ & 2701 & 37 & 02.09 .94 & $64^{\circ} 05^{\prime} 50^{\prime \prime}$ & 27우'ㅇ" & 1121 & 3.84 \\
\hline $\begin{array}{l}\text { McIntosh, } 1878 \\
\text { Ammotrypanella cf. arctica }\end{array}$ & 2704 & 16 & 02.09 .94 & $63 \div 50^{\prime} 50^{\prime \prime}$ & $27 \div 42^{\prime} 80^{\prime \prime}$ & 1295 & 3.80 \\
\hline $\begin{array}{l}\text { Mclntosh, } 1878 \\
\text { Ammotrypanella cf. arctica }\end{array}$ & 2706 & 6 & 03.09 .94 & $63 \div 55^{\prime} 80^{\prime \prime}$ & 2816'30" & 1406 & 3.71 \\
\hline $\begin{array}{l}\text { McIntosh, } 1878 \\
\text { Ammotrypanella cf. arctica }\end{array}$ & 2707 & 8 & 03.09 .94 & 635'ㅇ' & 28어'80" & 1407 & 3.71 \\
\hline $\begin{array}{l}\text { McIntosh, } 1878 \\
\text { Ammotrypanella cf. arctica }\end{array}$ & 2773 & 1 & 03.08 .95 & 69o14'89" & 14ㅇ16'52" & 1629 & -0.86 \\
\hline $\begin{array}{l}\text { McIntosh, } 1878 \\
\text { Ammotrypanella cf. arctica }\end{array}$ & 2777 & 1 & 03.08 .95 & 68으'80" & $14 \div 40^{\prime} 70^{\prime \prime}$ & 1556 & -0.78 \\
\hline $\begin{array}{l}\text { McIntosh, } 1878 \\
\text { Ammotrypanella cf. arctica }\end{array}$ & 2859 & 38 & 29.08 .95 & $61050 ' 22 "$ & $16052^{\prime} 86^{\prime \prime}$ & 2270 & 2.37 \\
\hline $\begin{array}{l}\text { McIntosh, } 1878 \\
\text { Ammotrypanella cf. arctica }\end{array}$ & 2860 & 63 & 30.08 .95 & 614' $43^{\prime \prime}$ & $16=57^{\prime} 48^{\prime \prime}$ & 2295 & 2.60 \\
\hline $\begin{array}{l}\text { McIntosh, } 1878 \\
\text { Ammotrypanella cf. arctica }\end{array}$ & 2863 & 30 & 30.08 .95 & 61ㅇ1'18" & $18^{\circ} 02^{\prime} 57^{\prime \prime}$ & 2400 & 2.07 \\
\hline $\begin{array}{l}\text { McIntosh, } 1878 \\
\text { Ammotrypanella cf. arctica }\end{array}$ & 2903 & 4 & 24.08 .96 & $65 \div 22^{\prime} 80^{\prime \prime}$ & $28020^{\prime} 63^{\prime \prime}$ & 1066 & 4.78 \\
\hline $\begin{array}{l}\text { McIntosh, } 1878 \\
\text { Ammotrypanella cf. arctica }\end{array}$ & 2908 & 8 & 25.08 .96 & 6515'67" & $28 \div 50 ' 27 "$ & 1301 & 3.96 \\
\hline $\begin{array}{l}\text { McIntosh, } 1878 \\
\text { Ammotrypanella cf. arctica }\end{array}$ & 2912 & 5 & 25.08 .96 & 6511'01" & 290'18" & 1456 & 3.90 \\
\hline $\begin{array}{l}\text { McIntosh, } 1878 \\
\text { Ammotrypanella cf. arctica }\end{array}$ & 3012 & 19 & 07.07.97 & $6122^{\prime} 20^{\prime \prime}$ & 15이'98" & 2133 & 3.29 \\
\hline $\begin{array}{l}\text { Mclntosh, } 1878 \\
\text { Ammotrypanella cf. arctica }\end{array}$ & 3072 & 1 & 12.07 .97 & $61953^{\prime} 65^{\prime \prime}$ & 150'15" & 2082 & 2.83 \\
\hline $\begin{array}{l}\text { McIntosh, } 1878 \\
\text { Ammotrypanella cf. arctica }\end{array}$ & 3073 & 9 & 12.07 .97 & 61이'ㄱ" & 150'ㄱ' & 2083 & 2.83 \\
\hline Mclntosh, 1878 & 3075 & 4 & 13.07 .97 & $62 \div 00 ' 19^{\prime \prime}$ & 1559'97" & 2192 & 3.07 \\
\hline
\end{tabular}




\begin{tabular}{|c|c|c|c|c|c|c|c|}
\hline Ammotrypanella cf. arctica & & & & & & & \\
\hline $\begin{array}{l}\text { Mclntosh, } 1878 \\
\text { Ammotrypanella cf. arctica }\end{array}$ & 3161 & 5 & 25.07 .00 & $62 \div 37^{\prime} 08^{\prime \prime}$ & $23 \div 21^{\prime} 79^{\prime \prime}$ & 1250 & 3.61 \\
\hline $\begin{array}{l}\text { Mclntosh, } 1878 \\
\text { Ammotrypanella cf. arctica }\end{array}$ & 3167 & 12 & 26.07 .00 & $60954 ' 88^{\prime \prime}$ & $22 \circ 47^{\prime} 26^{\prime \prime}$ & 1897 & 2.98 \\
\hline $\begin{array}{l}\text { McIntosh, } 1878 \\
\text { Ammotrypanella cf. arctica }\end{array}$ & 3173 & 1 & 28.07 .00 & $60 \div 05 ' 38 "$ & $20 \div 51^{\prime} 23^{\prime \prime}$ & 2709 & 2.68 \\
\hline $\begin{array}{l}\text { Mclntosh, } 1878 \\
\text { Ammotrypanella cf. arctica }\end{array}$ & 3204 & 75 & 08.07.01 & 6451'71" & 7ㅇ5'ㄷ'" & 2613 & -0.83 \\
\hline $\begin{array}{l}\text { McIntosh, } 1878 \\
\text { Ammotrypanella cf. arctica }\end{array}$ & 3208 & 75 & 09.07.01 & 6543'93" & 7응' $95^{\prime \prime}$ & 2002 & -0.87 \\
\hline $\begin{array}{l}\text { McIntosh, } 1878 \\
\text { Ammotrypanella cf. arctica }\end{array}$ & 3210 & 54 & 09.07.01 & 6613'66" & 6-51'77" & 2544 & -0.87 \\
\hline $\begin{array}{l}\text { McIntosh, } 1878 \\
\text { Ammotrypanella cf. arctica }\end{array}$ & 3214 & 695 & 10.07.01 & 6701'78" & 6011'83" & 3003 & -0.90 \\
\hline $\begin{array}{l}\text { McIntosh, } 1878 \\
\text { Ammotrypanella cf. arctica }\end{array}$ & 3216 & 56 & 11.07 .01 & 670''ㄷ" & 7은'12" & 2014 & -0.86 \\
\hline $\begin{array}{l}\text { McIntosh, } 1878 \\
\text { Ammotrypanella cf. arctica }\end{array}$ & 3219 & 35 & 11.07 .01 & 67ㅇ14'79" & 828'06" & 1642 & -0.82 \\
\hline $\begin{array}{l}\text { McIntosh, } 1878 \\
\text { Ammotrypanella cf. arctica }\end{array}$ & 3222 & 3 & 11.07 .01 & 67ㅇ5'77" & 80'94" & 1525 & -0.83 \\
\hline $\begin{array}{l}\text { Mclntosh, } 1878 \\
\text { Ammotrypanella cf. arctica }\end{array}$ & 3504 & 1 & 02.09 .02 & $622^{\circ} 01^{\prime} 46^{\prime \prime}$ & 1949'15" & 1733 & 3.09 \\
\hline $\begin{array}{l}\text { McIntosh, } 1878 \\
\text { Ammotrypanella cf. arctica }\end{array}$ & 3509 & 7 & 03.09 .02 & $62^{\circ} 02^{\prime} 40^{\prime \prime}$ & 19o38'71" & 1678 & 2.70 \\
\hline $\begin{array}{l}\text { McIntosh, } 1878 \\
\text { Ammotrypanella cf. arctica }\end{array}$ & 3514 & 1 & 04.09 .02 & $62 \div 25^{\prime} 59^{\prime \prime}$ & $19-46^{\prime} 15^{\prime \prime}$ & 1780 & 2.93 \\
\hline $\begin{array}{l}\text { Mclntosh, } 1878 \\
\text { Ammotrypanella cf. arctica }\end{array}$ & 3570 & 4 & 04.09 .03 & $63 \div 42^{\prime} 71^{\prime \prime}$ & 29o10'36" & 1819 & 3.24 \\
\hline $\begin{array}{l}\text { Mclntosh, } 1878 \\
\text { Ammotrypanella cf. arctica }\end{array}$ & 3573 & 2 & 05.09 .03 & $63 \div 22^{\prime} 49^{\prime \prime}$ & 295' $85 "$ & 2359 & 3.06 \\
\hline $\begin{array}{l}\text { McIntosh, } 1878 \\
\text { Ammotrypanella cf. arctica }\end{array}$ & 3621 & 4 & 14.07 .04 & 6629'39" & $9 \circ 44$ '80" & 1475 & -0.78 \\
\hline $\begin{array}{l}\text { McIntosh, } 1878 \\
\text { Ammotrypanella cf. arctica }\end{array}$ & 3624 & 19 & 14.07 .04 & $66059^{\prime} 48^{\prime \prime}$ & $8048^{\prime} 73^{\prime \prime}$ & 1628 & -0.82 \\
\hline $\begin{array}{l}\text { Mclntosh, } 1878 \\
\text { Ammotrypanella cf. arctica }\end{array}$ & 3628 & 15 & 15.07 .04 & 67ㅇ19'53" & 932'76" & 1609 & -0.81 \\
\hline $\begin{array}{l}\text { Mclntosh, } 1878 \\
\text { Ammotrypanella cf. arctica }\end{array}$ & 3632 & 100 & 16.07 .04 & 6800'92" & 9-14'78" & 1727 & -0.82 \\
\hline $\begin{array}{l}\text { McIntosh, } 1878 \\
\text { Ammotrypanella cf. arctica }\end{array}$ & 3633 & 191 & 17.07.04 & $68=25^{\prime} 12^{\prime \prime}$ & 85'72" & 1952 & -0.84 \\
\hline $\begin{array}{l}\text { McIntosh, } 1878 \\
\text { Ammotrypanella cf. arctica }\end{array}$ & 3636 & 7 & 17.07.04 & 6849'71" & 9o14'42" & 1844 & -0.81 \\
\hline $\begin{array}{l}\text { McIntosh, } 1878 \\
\text { Ammotrypanella cf. arctica }\end{array}$ & 3637 & 175 & 17.07.04 & 6826'92" & $10 \circ 08^{\prime} 75^{\prime \prime}$ & 2069 & -0.80 \\
\hline $\begin{array}{l}\text { McIntosh, } 1878 \\
\text { Ammotrypanella cf. arctica }\end{array}$ & 3638 & 1 & 18.07.04 & $68026^{\prime} 63^{\prime \prime}$ & 1010'58" & 2065 & -0.80 \\
\hline $\begin{array}{l}\text { McIntosh, } 1878 \\
\text { Ammotrypanella cf. arctica }\end{array}$ & 3640 & 120 & 18.07 .04 & 67ㅇ5'63" & $10 \circ 02^{\prime} 61^{\prime \prime}$ & 1915 & -0.82 \\
\hline $\begin{array}{l}\text { McIntosh, } 1878 \\
\text { Ammotrypanella cf. arctica }\end{array}$ & 3645 & 12 & 21.07 .04 & $67 \div 24^{\prime} 22^{\prime \prime}$ & $10 \cong 40^{\prime} 59^{\prime \prime}$ & 1703 & -0.81 \\
\hline $\begin{array}{l}\text { McIntosh, } 1878 \\
\text { Ammotrypanella cf. arctica }\end{array}$ & 3648 & 41 & 22.07 .04 & 685ㄱ'10" & $10032^{\prime} 80^{\prime \prime}$ & 2215 & -0.79 \\
\hline $\begin{array}{l}\text { McIntosh, } 1878 \\
\text { Ammotrypanella cf. arctica }\end{array}$ & 3649 & 9 & 22.07 .04 & $68 \div 56^{\prime} 45^{\prime \prime}$ & $10035^{\prime} 65^{\prime \prime}$ & 2214 & -0.79 \\
\hline $\begin{array}{l}\text { Mclntosh, } 1878 \\
\text { Ammotrypanella cf. arctica }\end{array}$ & 3652 & 146 & 22.07 .04 & $69904 ' 00^{\prime \prime}$ & $13 \div 33^{\prime} 85^{\prime \prime}$ & 1678 & -0.81 \\
\hline $\begin{array}{l}\text { McIntosh, } 1878 \\
\text { Ammotrypanella cf. arctica }\end{array}$ & 2027 & 1 & 23.07 .91 & 67ำ1'82" & $13 \div 20^{\prime} 58^{\prime \prime}$ & 1648 & -0.76 \\
\hline $\begin{array}{l}\text { Mclntosh, } 1878 \\
\text { Ammotrypanella cf. arctica }\end{array}$ & 2077 & 2 & 03.07 .92 & 67눙'51" & 17웅'38" & 1048 & -0.52 \\
\hline $\begin{array}{l}\text { McIntosh, } 1878 \\
\text { Ammotrypanella cf. arctica }\end{array}$ & 2257 & 28 & 05.09 .92 & 6314'61" & 2629'14" & 1209 & 4.09 \\
\hline Mclntosh, 1878 & 2310 & 116 & 11.09 .92 & 6334'09" & $22 \div 42^{\prime} 73^{\prime \prime}$ & 172 & 7.30 \\
\hline
\end{tabular}




\begin{tabular}{|c|c|c|c|c|c|c|c|}
\hline Ammotrypanella cf. arctica & & & & & & & \\
\hline $\begin{array}{l}\text { Mclntosh, } 1878 \\
\text { Ammotrypanella cf. arctica }\end{array}$ & 2403 & 12 & 01.07 .93 & $63 \div 02^{\prime} 90^{\prime \prime}$ & 21ㄴㅇ'60" & 838 & 5.49 \\
\hline $\begin{array}{l}\text { Mclntosh, } 1878 \\
\text { Ammotrypanella cf. arctica }\end{array}$ & 2404 & 1 & 01.07 .93 & $63 \div 02^{\prime} 30^{\prime \prime}$ & $21950 ' 80^{\prime \prime}$ & 802 & 5.49 \\
\hline $\begin{array}{l}\text { McIntosh, } 1878 \\
\text { Ammotrypanella cf. arctica }\end{array}$ & 2406 & 6 & 01.07 .93 & $62 \div 59 ' 20^{\prime \prime}$ & $21 \div 47^{\prime} 00^{\prime \prime}$ & 934 & 4.57 \\
\hline $\begin{array}{l}\text { Mclntosh, } 1878 \\
\text { Ammotrypanella cf. arctica }\end{array}$ & 2410 & 2 & 02.07 .93 & $62 \div 51^{\prime} 60^{\prime \prime}$ & 21여'10" & 1074 & 4.00 \\
\hline $\begin{array}{l}\text { McIntosh, } 1878 \\
\text { Ammotrypanella cf. arctica }\end{array}$ & 2415 & 7 & 02.07 .93 & 63000'18" & 21ㅇ0' $54 "$ & 819 & 5.36 \\
\hline $\begin{array}{l}\text { McIntosh, } 1878 \\
\text { Ammotrypanella cf. arctica }\end{array}$ & 2429 & 1 & 03.07 .93 & $63 \div 07^{\prime} 00^{\prime \prime}$ & $19-56^{\prime} 60^{\prime \prime}$ & 1072 & 4.80 \\
\hline $\begin{array}{l}\text { McIntosh, } 1878 \\
\text { Ammotrypanella cf. arctica }\end{array}$ & 2430 & 1 & 03.07 .93 & $63 \div 07^{\prime} 90^{\prime \prime}$ & $19-57^{\prime} 20^{\prime \prime}$ & 1016 & 4.80 \\
\hline $\begin{array}{l}\text { McIntosh, } 1878 \\
\text { Ammotrypanella cf. arctica }\end{array}$ & 2475 & 2 & 05.07 .93 & $63 \div 04 ' 20^{\prime \prime}$ & 21여'90" & 842 & 5.54 \\
\hline $\begin{array}{l}\text { McIntosh, } 1878 \\
\text { Ammotrypanella cf. arctica }\end{array}$ & 2514 & 1 & 13.07 .93 & $66034 ' 08 "$ & $25 \div 13^{\prime} 68^{\prime \prime}$ & 465 & -0.34 \\
\hline $\begin{array}{l}\text { McIntosh, } 1878 \\
\text { Ammotrypanella cf. arctica }\end{array}$ & 2697 & 9 & 02.09 .94 & 6410'20" & $2743^{\prime} 10^{\prime \prime}$ & 1042 & 4.20 \\
\hline $\begin{array}{l}\text { McIntosh, } 1878 \\
\text { Ammotrypanella cf. arctica }\end{array}$ & 2698 & 1 & 02.09 .94 & $64 \div 10^{\prime} 50^{\prime \prime}$ & $27 \div 42^{\prime} 60^{\prime \prime}$ & 1038 & 4.20 \\
\hline $\begin{array}{l}\text { McIntosh, } 1878 \\
\text { Ammotrypanella cf. arctica }\end{array}$ & 2700 & 8 & 02.09 .94 & $64^{\circ} 05^{\prime} 60^{\prime \prime}$ & 27응'00" & 1105 & 3.84 \\
\hline $\begin{array}{l}\text { Mclntosh, } 1878 \\
\text { Ammotrypanella cf. arctica }\end{array}$ & 2701 & 37 & 02.09.94 & $64 \div 05 ' 50 "$ & 27ㅇำ'70" & 1121 & 3.84 \\
\hline $\begin{array}{l}\text { Mclntosh, } 1878 \\
\text { Ammotrypanella cf. arctica }\end{array}$ & 2704 & 16 & 02.09 .94 & $63 \div 50 ' 50 "$ & 27은' $80^{\prime \prime}$ & 1295 & 3.80 \\
\hline $\begin{array}{l}\text { Mclntosh, } 1878 \\
\text { Ammotrypanella cf. arctica }\end{array}$ & 2706 & 6 & 03.09.94 & $63 \div 55^{\prime} 80^{\prime \prime}$ & 2816'30" & 1406 & 3.71 \\
\hline $\begin{array}{l}\text { McIntosh, } 1878 \\
\text { Ammotrypanella cf. arctica }\end{array}$ & 2707 & 8 & 03.09.94 & $63 \div 55^{\prime} 30^{\prime \prime}$ & 2816'80" & 1407 & 3.71 \\
\hline $\begin{array}{l}\text { McIntosh, } 1878 \\
\text { Ammotrypanella cf. arctica }\end{array}$ & 2773 & 1 & 03.08 .95 & 69o14'89" & $14016^{\prime} 52^{\prime \prime}$ & 1629 & -0.86 \\
\hline $\begin{array}{l}\text { McIntosh, } 1878 \\
\text { Ammotrypanella cf. arctica }\end{array}$ & 2777 & 1 & 03.08 .95 & $68 \div 36^{\prime} 80^{\prime \prime}$ & $14 \div 40^{\prime} 70^{\prime \prime}$ & 1556 & -0.78 \\
\hline $\begin{array}{l}\text { Mclntosh, } 1878 \\
\text { Ammotrypanella cf. arctica }\end{array}$ & 2859 & 38 & 29.08 .95 & $61950 ' 22 "$ & $16052^{\prime} 86^{\prime \prime}$ & 2270 & 2.37 \\
\hline $\begin{array}{l}\text { McIntosh, } 1878 \\
\text { Ammotrypanella cf. arctica }\end{array}$ & 2860 & 63 & 30.08 .95 & 61녀'43" & $16057^{\prime} 48^{\prime \prime}$ & 2295 & 2.60 \\
\hline $\begin{array}{l}\text { McIntosh, } 1878 \\
\text { Ammotrypanella cf. arctica }\end{array}$ & 2863 & 30 & 30.08 .95 & 61이'18" & $18902^{\prime} 57^{\prime \prime}$ & 2400 & 2.07 \\
\hline $\begin{array}{l}\text { McIntosh, } 1878 \\
\text { Ammotrypanella cf. arctica }\end{array}$ & 2903 & 4 & 24.08 .96 & $65 \div 22^{\prime} 80^{\prime \prime}$ & $28 \div 20^{\prime} 63^{\prime \prime}$ & 1066 & 4.78 \\
\hline $\begin{array}{l}\text { McIntosh, } 1878 \\
\text { Ammotrypanella cf. arctica }\end{array}$ & 2908 & 8 & 25.08 .96 & 6515'67" & $28 \div 50 ' 27 "$ & 1301 & 3.96 \\
\hline $\begin{array}{l}\text { Mclntosh, } 1878 \\
\text { Ammotrypanella cf. arctica }\end{array}$ & 2912 & 5 & 25.08 .96 & 6511'01" & 2904'18" & 1456 & 3.90 \\
\hline $\begin{array}{l}\text { McIntosh, } 1878 \\
\text { Ammotrypanella cf. arctica }\end{array}$ & 3012 & 19 & 07.07.97 & $6122^{\prime} 20^{\prime \prime}$ & 15이' $98^{\prime \prime}$ & 2133 & 3.29 \\
\hline $\begin{array}{l}\text { McIntosh, } 1878 \\
\text { Ammotrypanella cf. arctica }\end{array}$ & 3072 & 1 & 12.07 .97 & $61053^{\prime} 65^{\prime \prime}$ & $15 \div 08^{\prime} 15^{\prime \prime}$ & 2082 & 2.83 \\
\hline $\begin{array}{l}\text { McIntosh, } 1878 \\
\text { Ammotrypanella cf. arctica }\end{array}$ & 3073 & 9 & 12.07 .97 & 61ㅇ5'78" & 150'ㄱ' & 2083 & 2.83 \\
\hline $\begin{array}{l}\text { Mclntosh, } 1878 \\
\text { Ammotrypanella cf. arctica }\end{array}$ & 3075 & 4 & 13.07.97 & $622^{\circ} 00^{\prime} 19^{\prime \prime}$ & $15 \div 59^{\prime} 97^{\prime \prime}$ & 2192 & 3.07 \\
\hline $\begin{array}{l}\text { McIntosh, } 1878 \\
\text { Ammotrypanella cf. arctica }\end{array}$ & 3161 & 5 & 25.07 .00 & $62 \div 37^{\prime} 08^{\prime \prime}$ & 2321'79" & 1250 & 3.61 \\
\hline $\begin{array}{l}\text { Mclntosh, } 1878 \\
\text { Ammotrypanella cf. arctica }\end{array}$ & 3167 & 12 & 26.07 .00 & $60 \div 54 ' 88^{\prime \prime}$ & $22 \div 47^{\prime} 26^{\prime \prime}$ & 1897 & 2.98 \\
\hline $\begin{array}{l}\text { McIntosh, } 1878 \\
\text { Ammotrypanella cf. arctica }\end{array}$ & 3173 & 1 & 28.07 .00 & $60 \circ 05^{\prime} 38^{\prime \prime}$ & $20-51^{\prime} 23^{\prime \prime}$ & 2709 & 2.68 \\
\hline Mclntosh, 1878 & 3204 & 75 & 08.07.01 & 6451'71" & 7ㅇ5'ㄷ' & 2613 & -0.83 \\
\hline
\end{tabular}




\begin{tabular}{|c|c|c|c|c|c|c|c|}
\hline Ammotrypanella cf. arctica & & & & & & & \\
\hline $\begin{array}{l}\text { McIntosh, } 1878 \\
\text { Ammotrypanella cf. arctica }\end{array}$ & 3208 & 75 & 09.07 .01 & 654'93" & 7으'ㄷ' & 2002 & -0.87 \\
\hline $\begin{array}{l}\text { McIntosh, } 1878 \\
\text { Ammotrypanella cf. arctica }\end{array}$ & 3210 & 54 & 09.07 .01 & $66 \div 13^{\prime} 66^{\prime \prime}$ & $6 \div 51^{\prime} 77^{\prime \prime}$ & 2544 & -0.87 \\
\hline $\begin{array}{l}\text { McIntosh, } 1878 \\
\text { Ammotrypanella cf. arctica }\end{array}$ & 3214 & 695 & 10.07 .01 & 670ㅜㄱ' $78^{\prime \prime}$ & 6o11'83" & 3003 & -0.90 \\
\hline $\begin{array}{l}\text { Mclntosh, } 1878 \\
\text { Ammotrypanella cf. arctica }\end{array}$ & 3216 & 56 & 11.07 .01 & $67^{\circ} 05^{\prime} 86^{\prime \prime}$ & 7은'12" & 2014 & -0.86 \\
\hline $\begin{array}{l}\text { McIntosh, } 1878 \\
\text { Ammotrypanella cf. arctica }\end{array}$ & 3219 & 35 & 11.07 .01 & 67ำ14'79" & $8 \div 28 ' 06^{\prime \prime}$ & 1642 & -0.82 \\
\hline $\begin{array}{l}\text { McIntosh, } 1878 \\
\text { Ammotrypanella cf. arctica }\end{array}$ & 3222 & 3 & 11.07 .01 & 67ㅇ5'ㄱ"' & 805'94" & 1525 & -0.83 \\
\hline $\begin{array}{l}\text { McIntosh, } 1878 \\
\text { Ammotrypanella cf. arctica }\end{array}$ & 3504 & 1 & 02.09 .02 & $62^{\circ} 01^{\prime} 46^{\prime \prime}$ & $19 \circ 49^{\prime} 15^{\prime \prime}$ & 1733 & 3.09 \\
\hline $\begin{array}{l}\text { Mclntosh, } 1878 \\
\text { Ammotrypanella cf. arctica }\end{array}$ & 3509 & 7 & 03.09 .02 & $62^{\circ} 02^{\prime} 40^{\prime \prime}$ & $19 \div 38^{\prime} 71^{\prime \prime}$ & 1678 & 2.70 \\
\hline $\begin{array}{l}\text { Mclntosh, } 1878 \\
\text { Ammotrypanella cf. arctica }\end{array}$ & 3514 & 1 & 04.09 .02 & $62 \div 25^{\prime} 59^{\prime \prime}$ & $19 \circ 46^{\prime} 15^{\prime \prime}$ & 1780 & 2.93 \\
\hline $\begin{array}{l}\text { Mclntosh, } 1878 \\
\text { Ammotrypanella cf. arctica }\end{array}$ & 3570 & 4 & 04.09 .03 & $63 \div 42^{\prime} 71^{\prime \prime}$ & 2910'36" & 1819 & 3.24 \\
\hline $\begin{array}{l}\text { McIntosh, } 1878 \\
\text { Ammotrypanella cf. arctica }\end{array}$ & 3573 & 2 & 05.09 .03 & $63 \div 22^{\prime} 49^{\prime \prime}$ & 29o54'85" & 2359 & 3.06 \\
\hline $\begin{array}{l}\text { McIntosh, } 1878 \\
\text { Ammotrypanella cf. arctica }\end{array}$ & 3621 & 4 & 14.07 .04 & 6629'39" & $9 \circ 44^{\prime} 80^{\prime \prime}$ & 1475 & -0.78 \\
\hline $\begin{array}{l}\text { Mclntosh, } 1878 \\
\text { Ammotrypanella cf. arctica }\end{array}$ & 3624 & 19 & 14.07 .04 & $66=59^{\prime} 48^{\prime \prime}$ & 8ㄴ4' $73^{\prime \prime}$ & 1628 & -0.82 \\
\hline $\begin{array}{l}\text { Mclntosh, } 1878 \\
\text { Ammotrypanella cf. arctica }\end{array}$ & 3628 & 15 & 15.07 .04 & 67ํ19'53" & 9-32'76" & 1609 & -0.81 \\
\hline $\begin{array}{l}\text { Mclntosh, } 1878 \\
\text { Ammotrypanella cf. arctica }\end{array}$ & 3632 & 100 & 16.07 .04 & 6800'92" & 914'78" & 1727 & -0.82 \\
\hline $\begin{array}{l}\text { McIntosh, } 1878 \\
\text { Ammotrypanella cf. arctica }\end{array}$ & 3633 & 191 & 17.07 .04 & $68 \div 25^{\prime} 12^{\prime \prime}$ & $8057^{\prime} 72^{\prime \prime}$ & 1952 & -0.84 \\
\hline $\begin{array}{l}\text { Mclntosh, } 1878 \\
\text { Ammotrypanella cf. arctica }\end{array}$ & 3636 & 7 & 17.07.04 & 6849'71" & 914'42" & 1844 & -0.81 \\
\hline $\begin{array}{l}\text { McIntosh, } 1878 \\
\text { Ammotrypanella cf. arctica }\end{array}$ & 3637 & 175 & 17.07 .04 & $68 \div 26^{\prime} 92^{\prime \prime}$ & $10^{\circ} 08^{\prime} 75^{\prime \prime}$ & 2069 & -0.80 \\
\hline $\begin{array}{l}\text { Mclntosh, } 1878 \\
\text { Ammotrypanella cf. arctica }\end{array}$ & 3638 & 1 & 18.07.04 & $68 \div 26^{\prime} 63^{\prime \prime}$ & $10 \div 10^{\prime} 58^{\prime \prime}$ & 2065 & -0.80 \\
\hline $\begin{array}{l}\text { Mclntosh, } 1878 \\
\text { Ammotrypanella cf. arctica }\end{array}$ & 3640 & 120 & 18.07.04 & 67ㅇ5'63" & $10 \div 02^{\prime} 61^{\prime \prime}$ & 1915 & -0.82 \\
\hline $\begin{array}{l}\text { Mclntosh, } 1878 \\
\text { Ammotrypanella cf. arctica }\end{array}$ & 3645 & 12 & 21.07 .04 & 67은'22" & $10 \div 40^{\prime} 59^{\prime \prime}$ & 1703 & -0.81 \\
\hline $\begin{array}{l}\text { McIntosh, } 1878 \\
\text { Ammotrypanella cf. arctica }\end{array}$ & 3648 & 41 & 22.07 .04 & $68 \div 57^{\prime} 10^{\prime \prime}$ & $10 \div 32^{\prime} 80^{\prime \prime}$ & 2215 & -0.79 \\
\hline $\begin{array}{l}\text { Mclntosh, } 1878 \\
\text { Ammotrypanella cf. arctica }\end{array}$ & 3649 & 9 & 22.07 .04 & $68 \div 56^{\prime} 45^{\prime \prime}$ & $10035^{\prime} 65^{\prime \prime}$ & 2214 & -0.79 \\
\hline Mclntosh, 1878 & 3652 & 146 & 22.07 .04 & 6904'00" & $13 \div 33^{\prime} 85^{\prime \prime}$ & 1678 & -0.81 \\
\hline
\end{tabular}

